Historic, Archive Document

Do not assume content reflects current scientific knowledge, policies, or practices. 



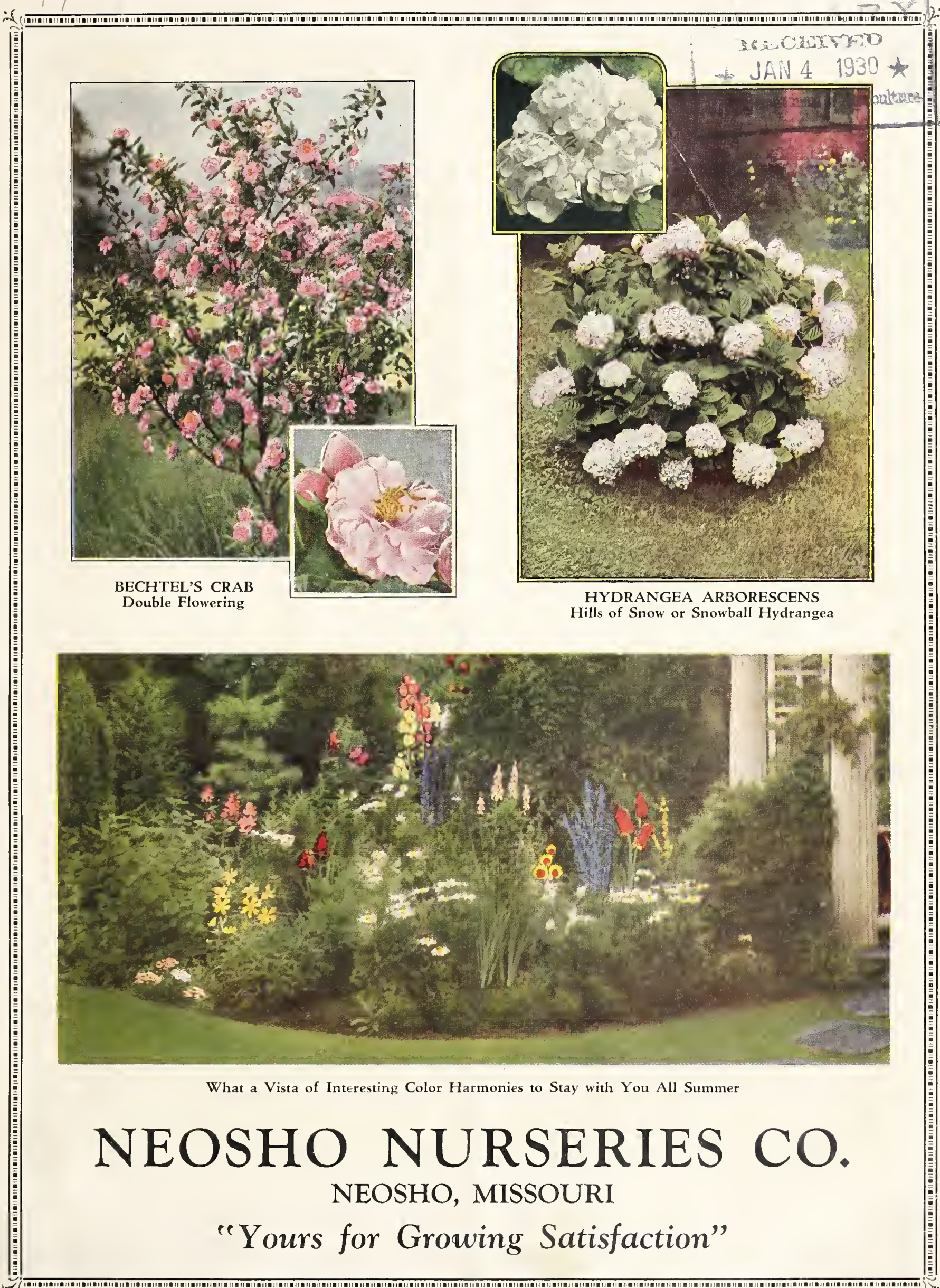



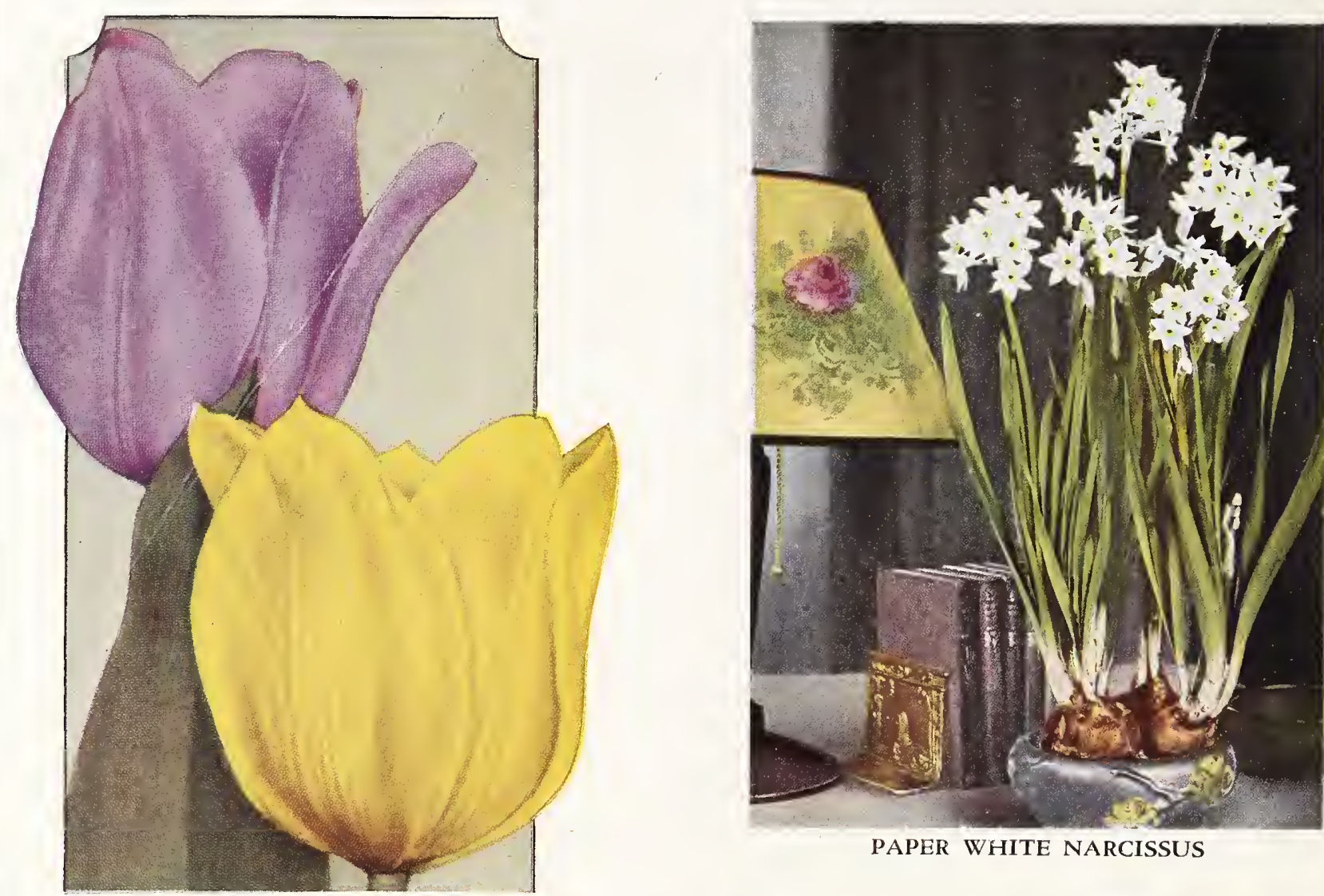

DARWIN TULIPS
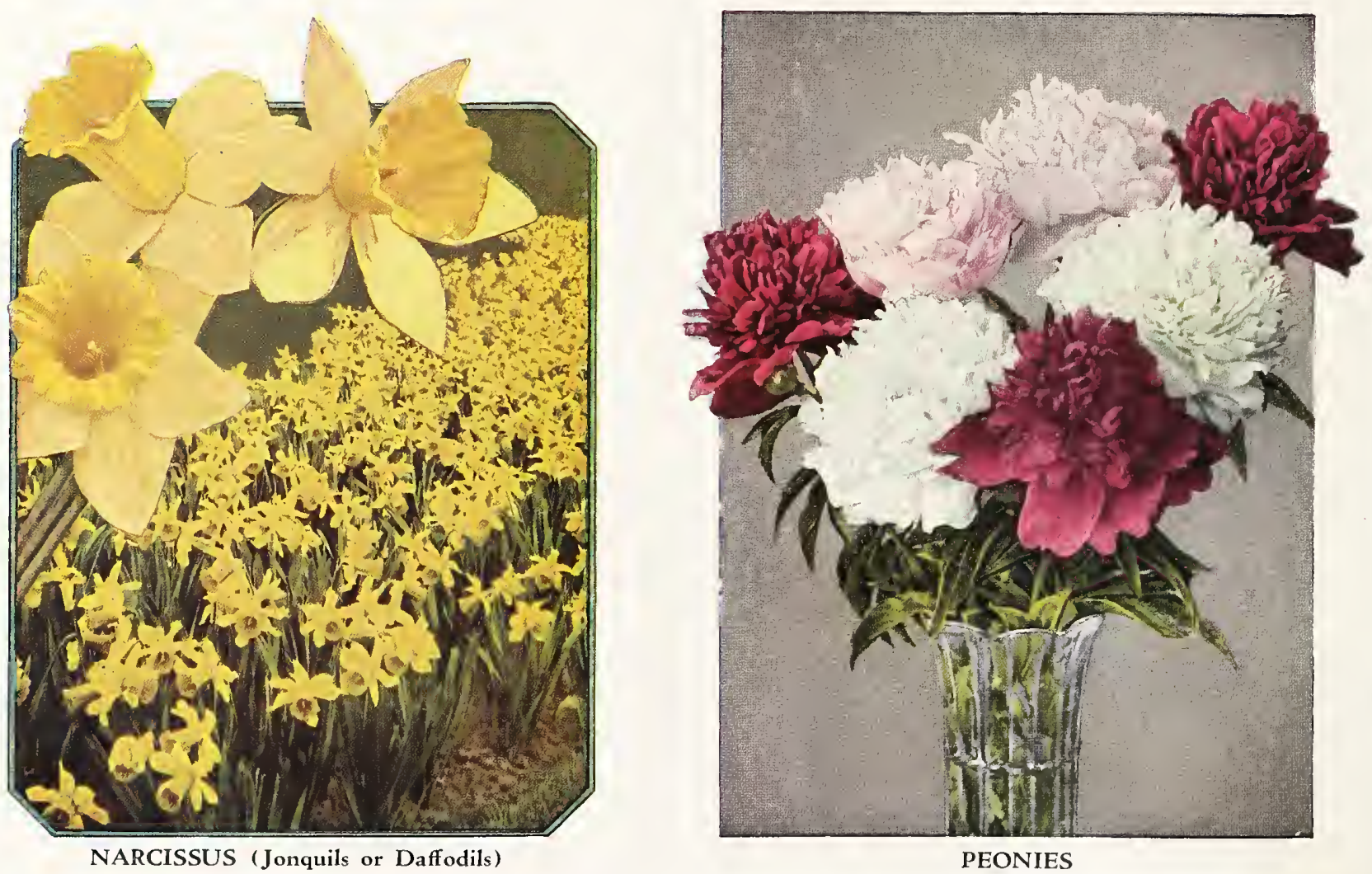

To Enjoy These Beautiful Flowers Next Spring, at Little Expense and Trouble, Plant Our No. $1 \mathrm{r}$ NEOSHO NURSERIES CO., Neosho, Mi' 


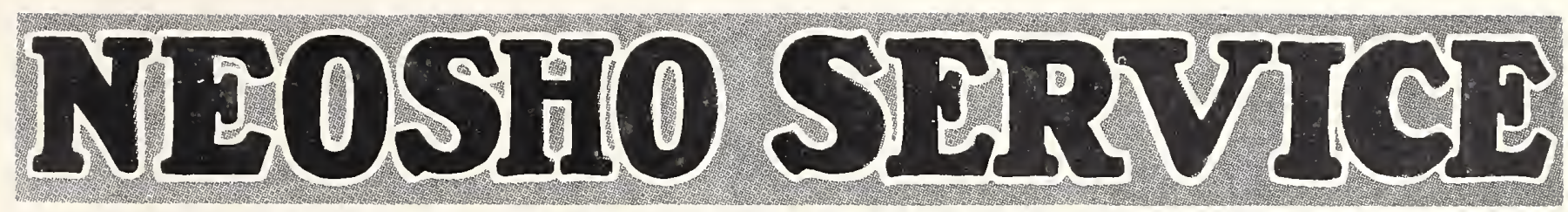

"In all commercial activities a reputation for trustworthiness is the most valuable of assets, but for the nurseryman and seedsman it is absolutely indispensable."

Nurserymen have a difficult selling problem. Their products cannot be definitely described because there is so much variation in the habits of growth even of different varieties of the same kind. For instance in two-year apple trees, the York Imperial makes a handsome tree in the nursery while the Delicious is inclined to have a somewhat crooked trunk and fewer side branches. In roses the Radiance is a strong grower while the Maman Cochet has lighter branches and roots.

Even if the nur'seryman could accurately describe each variety as to height, diameter of trunk, number of branches, or quantity of roots, there is no way to describe vitality. That indispensable quality will be present only if digging is done at the right time without exposure to drying sun and winds, if stock is kept at the correct degrees of temperature and moisture, and is packed to reach the customer in good condition. Therefore, the buyer must trust the nurseryman to furnish trustworthy products. Reliable information on how best to use, handle and care for nursery products is also indispensable to most buyers.

We adopted as our motto or slogan, "Yours for Growing Satisfaction." It sums up our quality products and helpful service, but it also serves as an inspiration and a guide in our dealings with our customers and in all our operations.

\section{WHEN TO PLANT}

The best time to plant depends upon climate, weather and soil conditions and kinds or varieties of trees and plants.

\section{FALL PLANTING DATES}

In Southwest Missouri the average dates for fruit trees, ornamental trees and shrubs are from October 25 th into December. Tulips, Hyacinths and Nurcissus and some Lilies must be set out in September, October or November. Peonies are best planted in the fall and Iris almost any time after vlooming. Early blooming Perennials can be planted to good advantage in the fall. The dates for Lawn Seeding run from September 15th to November 1. Ever- greens are set out from September 15th into December.

Further north the season ends earlier, about November 10th in Minneapolis.

Further south the season is extended until in some districts it runs from about November 1st to April 1st.

\section{SPRING PLANTING DATES}

The average dates for this district rum from early March to May 25th. Further north it begins and also ends later, and just the reverse in warmer districts. The season for Lawn Seeding runs about March 10th to May 1st. Evergreens from March 10th into June. Commercial plantings should be in the ground before the spring rains. Snraller plantings, fruit or ornamentals which can be watered, can be made much later.
Shallow rooted plants like Blackberries and Raspberries are usually set in the spring. If planted in the fall they must be protected against injury from alternate freezing and thawing of the ground by a mound of dirt over the tops.

PLANTS 'THAT RECOVER SLOWIY FROM TRANSPLANTING

Althea (Hibiscus Syriacus), Abelia Grandiflora, American Holly (Ilex Opaca), Birch (Betula), Common Box (Buxus Sempervirens), Flowering Crab (Malus), Flowering Dogwood (Cornus Florida), Common Lilac (Syringa Vulgaris), Oregon Grape (Mahonia Aquifolia), Red Oak (Quercus Rubra), Red Bud or Judas Tree (Cercis Canadensis), Thorn (Crataegus), Tulip (Liriodendron).

The Information from our "How to Beautify Your Home Grounds" and "Inside Facts of Profitable Fruit Growing" is included in this Catalog.

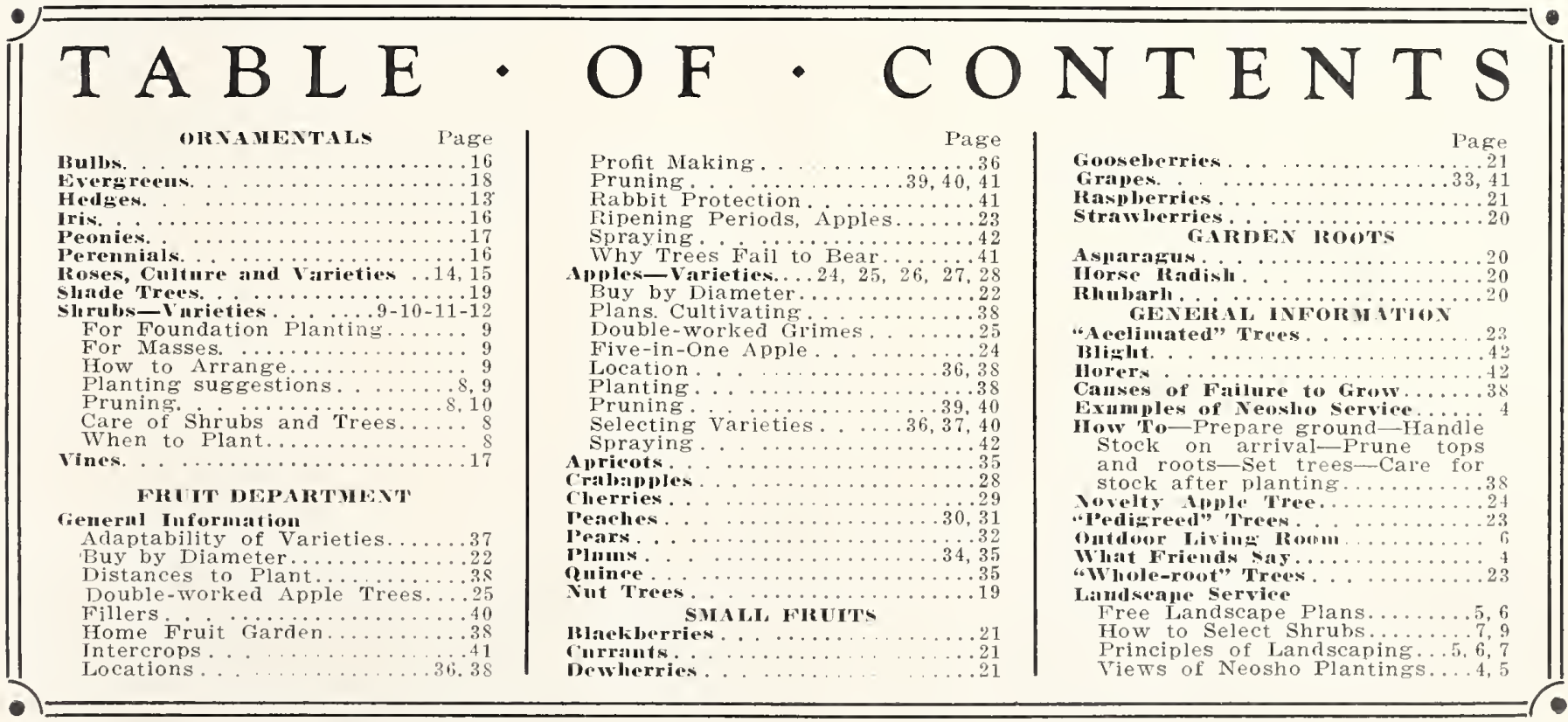




\section{The Entire Neosho Organization Stands Back of Your Order}

Here are Some of the Ways We Have Rendered Our Customers Neosho Service-We're Waiting to Serve You!

T AST spring a customer gave us a nice order for fruit $\mathcal{L}$ trees saying, "Perhaps you recall telling me a couple of years ago to postpone planting fruit trees on my newly cleared land because of danger of loss from root-rot."

An order came from Oklahoma for 50 Baldwin apple trees. We told the customer this is a northern variety and would not be likely to give satisfaction, but we could supply them if he wished to take the risk. He changed his order to varieties of proven value in his district.

Mr. Mullens of Missouri planted 350 of our trees three years ago. His neighbor laughed at him for paying more than the neighbor did for trees purchased elsewhere. Today he has a fine orchard while his neighbor is a booster for Neosho stock.

An Arkansas customer sent us an order for 1000 peach trees 1 yr. 11/16-inch, 5 to 7 -ft. We wrote him to let us send him $9 / 16$ to $11 / 16$ and to cut back the tops to two feet. He was highly pleased with the stock and has since shown further orders for his
friends as well as for himself. L. C. Beirne of Ken-
tucli y wrote us about his tucky wrote us about his
J. H. Hale peaches from J. H. Hale peaches from have letters from every one to whom I shipped singing their praises. People here think I am quit a fruit man, but the truti is, 'Your Bools' has been my daily guide and cress I have made."

Note-In addition to this book we also supply at $15 \mathrm{c}$ per copy, "Grow is a big help in growin fruit. It contains 8 pages ant trations.

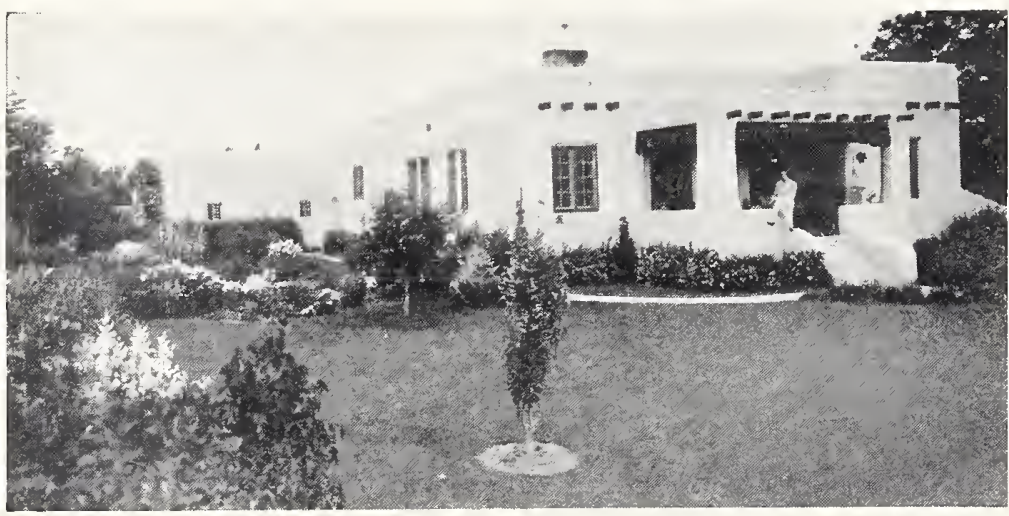

A GENTLEMAN from a near-by city called late last A spring to buy some shrubs and trees for his home, but had no idea of what varieties to use nor how to arrange them. Fortunately he had some pictures of the house and could give us the data we needed. So we made him a rough plan and furnished the plant material required. We even pruned each shrub ready for planting. He reports excellent results.

A lady wanted to use crimson Spirea at the corners of her house and Spirea Van Houttei under the windows, until we pointed out that the habits of growth of these shrubs make this arrangement out of harmony.

Another customer planned to use the Butterfly Bush at the corners of the entrance, but quickly grasped our suggestion to place it in a less conspicuous place since its foliage is not attractive seen close at hand and it dies to the ground in winter.

"Your drawing and suggestions for the planting of my place have been duly received, and to say that I am pleased have given me is putting it mildly. the lind offices of Mr. Fred sloan of this place that I got in touch with your firm. Sloan owns a 13 . 000 apple and peach orchard here and has repeatedly told me that his best trees were purchased W. Jackson. Alleghany Co., Maryland.

"Your shrubbery and trees supplied last Apri proved to be very satis the raspberry bushes and the raspberry bushes an failures I do not attribute to you since the other stock was 100 per cent good and beyond my expectations." -John W. Jackson, Alleghany Co. Maryland.

This is the beautiful home of H. A. Wangerian, Santa Fe, N. M. He writes: "Practically everything was furnished

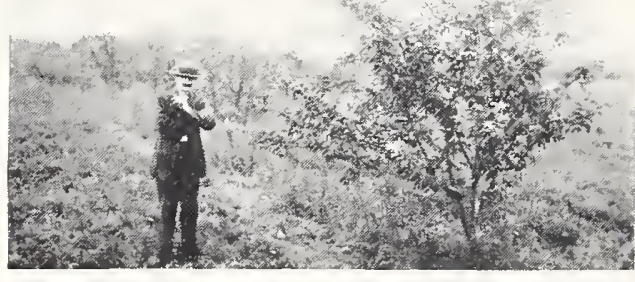

This photo from W. P. Murray, Michigan, Who Writes: "Your last shipment came
through a good bunch of trees. All have made a good growth." He has bought our trees for 7 years.

Below-Mr. and Mrs. C. L. Dickson, Nevada Mo., who write: "Planted 500 Neosho trees spring ' 26 and 500 in fall

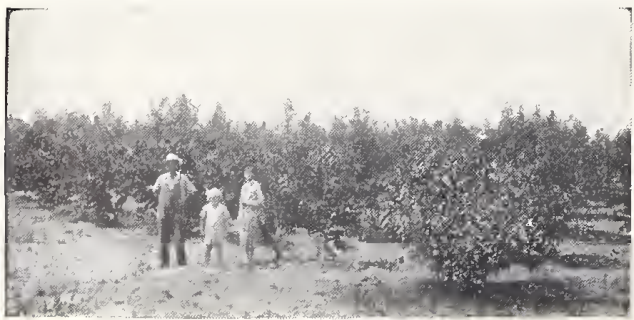

$\mathrm{Mr}$ Olmstead of $\mathrm{Ne}$ braska planted 2,952 of our trees spring 1928 (2,812 apple, 100 peach, 25 plum, 15 cherry). He wrote 11-22-28, "I an certainly glad to write and say how well pleased we were with the trees. Every apple tree lived. One peach died. Most of the trees made about a three foot growth."

In February, 1929, he gave us another order for 1,500 trees.

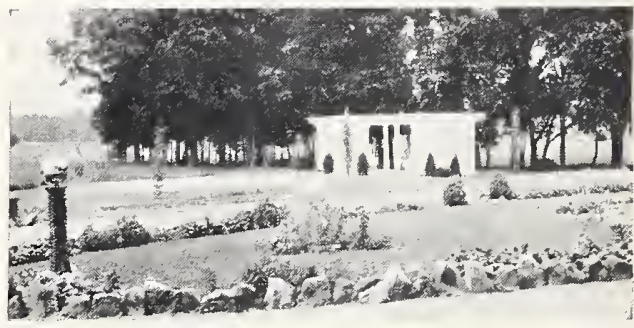

This is a view at Reed's Lodge, owned by Frank Reed of Neosho, Mo. This beautiful place was planted-with Neosho stock. Let place was planted with Neosho stock. Let grounds.

Below-This Jonathan apple tree is owned by Chas. Robbins, who lives near McEllnaney Mo. It was a 1 yr, $7 / 16$-in. tree when planted and was only 7 years old when this photo

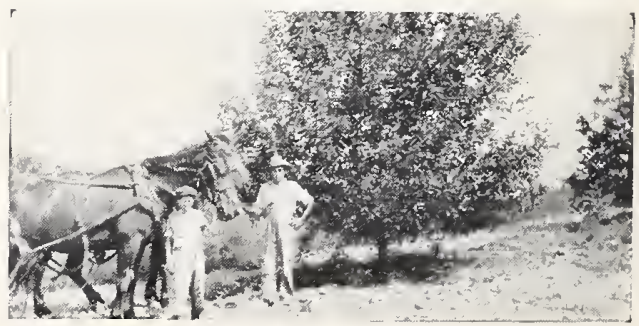




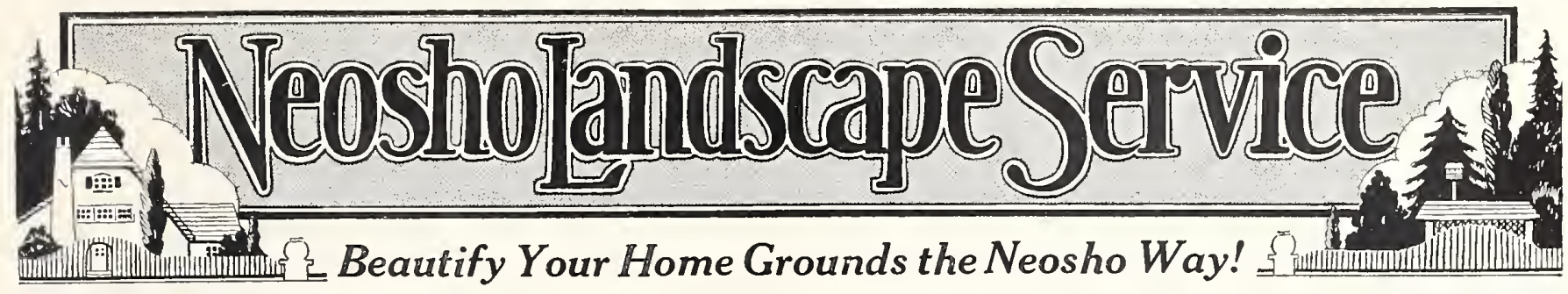

Everybody knows that the attractiveness, comfort and value of a home is greatly increased by the proper use of plant materials. Your guests enter your home when they set foot upon your property rather than when they cross your threshold.

Many people hesitate to beautify their home surroundings because they do not know the principles of landscaping, they are not familiar with the characteristics and habits of growth of plant materials, or they fear the cost will be prohibitive.

It does indeed require knowledge, experience and good taste to design plantings which will produce a pleasing picture and prove attractive to the passerby as well as to the owner, so that observers exclaim, "What a beautiful home" rather than "What lovely flowers" or "What a beautiful bush."

Our Landscape Architect, Mr. Woodard, is eminently well fitted by education, experience and natural ability to design plantings which please discriminating people, whether the property is public or private, large or small. His plans and our plant materials are giving satisfaction in New York, New Mexico and many other states far and near, including a contract for $\$ 4,500.00$ for a private estate in Arkansas.

Whenever a personal survey is necessary or preferred, our terms will be stated upon request.

In most cases with the cooperation of the owner we furnish by mail a plan or sketch which secures artistic attractive grounds, adapted to the owner's particular needs. Send us the information outlined on the following page with your check for $\$ 5.00$ which will be applied on the purchase of nursery stock when your order is received.

Mr. Woodard will then prepare a complete plan drawn to scale, showing the exact location of each shrub, tree, etc., and a detailed estimate of the cost of the necessary plants. This plan enables the owner to have each plant put in the proper place.

Let us remind you that a complete plan at the start is of vital importance in order to obtain harmonious effects, and reflect the taste and refinement of the owner.

A competent landscape architect should really be consulted before the house is located, even on a small plot, because the proper location on the lot with reference to the sun, the site, and the lawn area are of vital importance to the comfort, pleasure and enjoyment of the occupants.

Let us help you to solve your Landscape problems.

Below is a picture from a photograph of a new house in a nearby city. At the right is a drawing by our Landscape Architect which illustrates how the home would look after planting according to his plan. Note how well the plant materials are used to harmonize with the architectural features of the house.

This pen and ink sketch reflects Mr. Woodard's artistic ability.
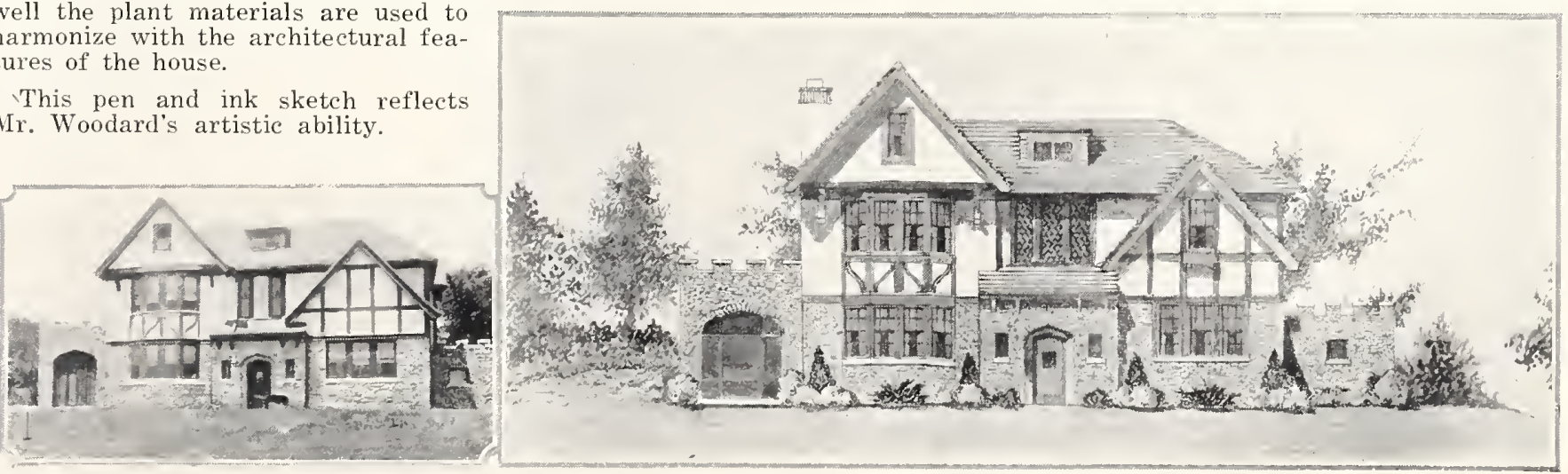


\section{How to Enjoy Neosho Landscape Service}

$\mathrm{O}$ UR Landscape Service is available to you even though your home is in a distant state. Send us a sketch and full information as specified below. We will then prepare a detailed plan, incorporating original ideas which will enable you to secure practical artistic effects which will increase the attractiveness, enjoyment and value of your property. With the information required send us your check for $\$ 5.00$ which will be applied on the purchase price of the trees, plants, etc., when your order is received.

The plan we submit for your approval will show the exact location of each tree, shrub, etc., and will furnish an accurate guide for planting. At the same time we will give you an estimate of the cost of the plant materials required.

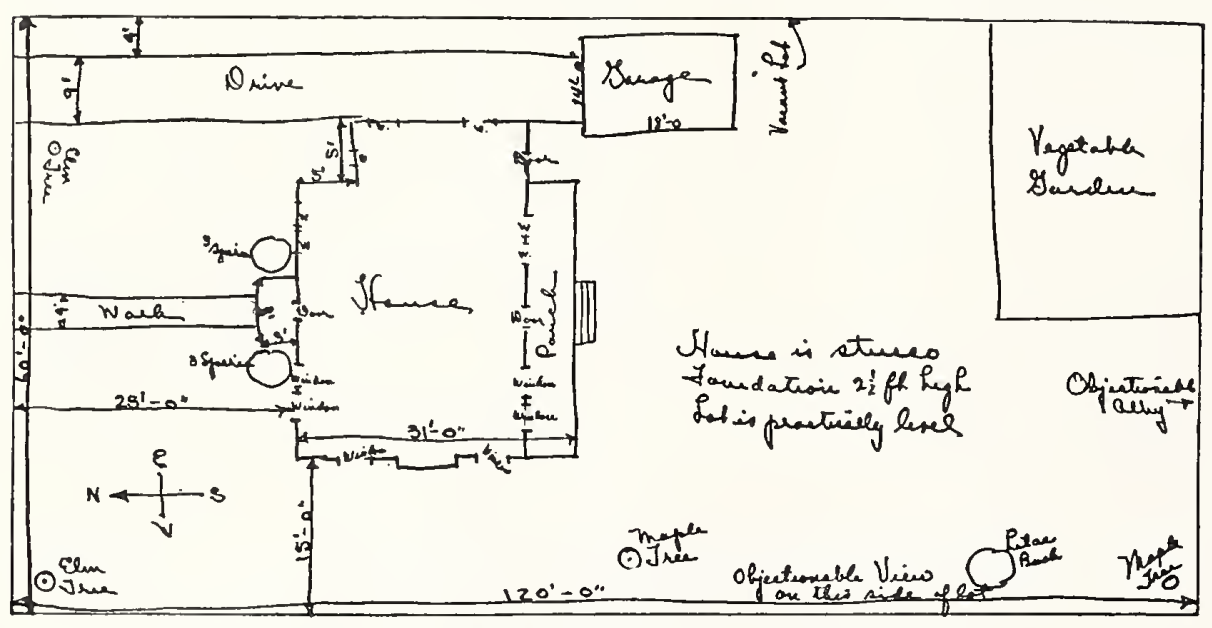

Example of rough sketch sent in loy customer.

\section{A Beautiful Place $\sim$ the Creation of an Artist}

In the plan shown below, developed from the rough sketch above, our rivet hedoe enclosing the front lawn. Flowering shrubs along part of the west side and the south end provide an attractive background, hide all objectionable views and secure privacy. The house is linked to the ground with low growing shrubs and Evergreens at each side of the front porch and rear steps. shrubs are also used in the flower borders to give added height and to soften angles at the corners.

The service yard and vegetable garlen ale separated from the flower garden by lattice fence on which are planted climbing roses and Boston Ivy.

A Japanese Barberry hedge around the vegetable garden serves as a barrier to keep out dogs, chickens, etc. Entrance to the service yard and vegetable garden is under a vine-covered arbor.

If desired this plan could be carried out over several years putting in the out over several years, putting in the the shrub borders, followed by the hedges, flower garden and lily pool. And hedges, flower garden and lily pool. And and artistic, which could not be attained and artistic, which could not be attaine
without a complete plan at the start.

A Thouklnt for owners of New liomes The ideal method of course is to prepare for the landscape development as soon as the land is purchased. Sunlight and breezes are particularly desired in certain rooms. The house should appear to grow naturally out of its site. It also makes a great difference how the walks and drives are arranged. Whether the house and lot is large or small the lawn space in front should be in proper proportion. Therefore a more beautiful artist has a clear canvas at the start.

\section{We Need This Information to Prepare Sketch for Your Grounds}

The drawing at the left shows how to prepare a rough sketch not drawn to scale to supply the information we must have. Please answer all ques-

Give all dimensions of building and

Show location of buildings on lot.

Give points of compass.

Show location of all trees and shrub-

bery. on place.

show location of all walks, drives,

Give all grades, show terraces, ete.

Show any objectionable views to be

Attach kodak views, taken from north, south, east and west sides of lot. if possible.

show where windows in first floor are placed.

Is the house one, two or three stories? Color of house-brick, frame or stone Height of foundation and windows. Do you like a lot of shrubbery?

Do you want any hedges?

Where preferred? and walks?

Do you prefer any particular kind of

Do you want a rose bed?

Do you want a formal flower garden? Do you want any fruit trees?

Do you want any ever oreens?

Do you want a vegetable garden? Where preferred?

Do rou want a rock garden?

What is the character of soil?

State how much you are willing to spend, also if you wish to plant part his spring and the balance next season.

No'TE-Your sketch need not be drawn to scale, just so you give us correct dimensions.

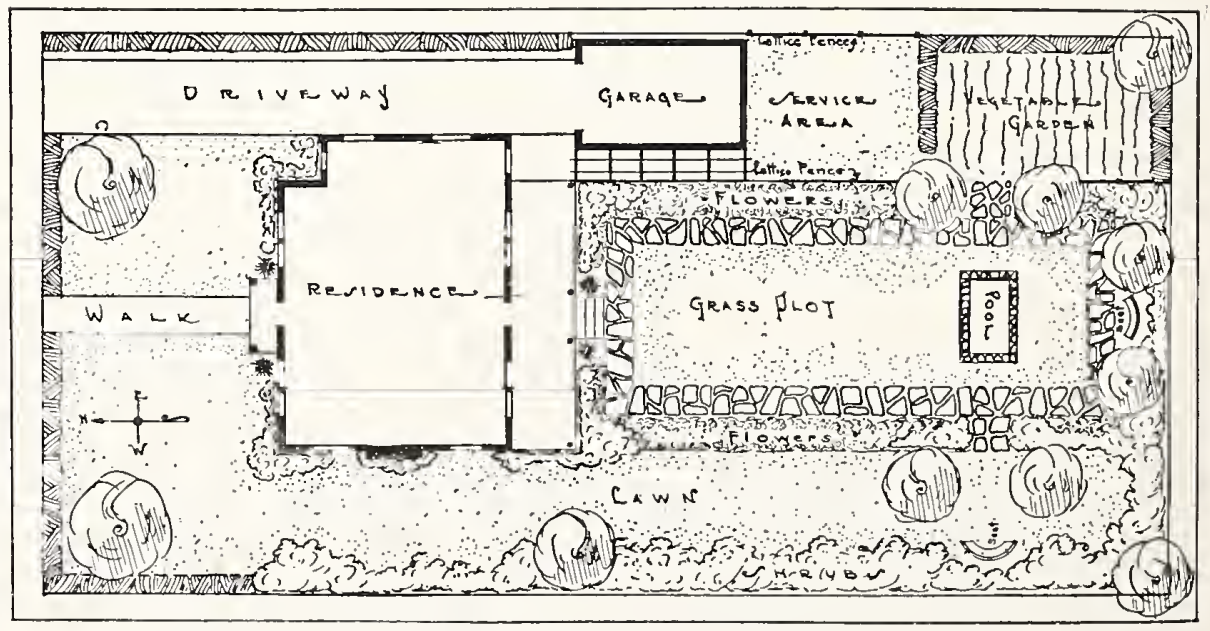




\section{Develop Your Grounds to an Artistic Plan}

\section{What a Beautiful Home!}

$\mathrm{THIS}$ drawing at the right was made by $\mathrm{Mr}$.

Woodard, our landscape architect. It il-

lustrates a home after appropriate plant-

ings have attained a few years'

growth.

You can enhance the beauty of your grounds and increase your property value at comparatively small expense if you will accept our Service. Every home is different. Let us help you to secure original, practical and artistic effects.

\section{Suggestions for De-} veloping Your Own

\section{Landscape Plan}

We can be happy and contented in homes that are not planted but our happiness and contentment can be increased by better surroundings-and now-a-days people are interested in improving their home property. Our free Landscape Service is explained on the opposite page, but for those who prefer to solve this problem for themselves and to help others to appre

the following suggestions are offered: One must first appreciate that the house, garage selection and ar rangement of plant materials must be made with the idea of harmonizing all objects. One must resist the temptation to use a shrub just for its flowers or an artificial tree like the Weeping Mulberry or an expensive specimen unless they fit into the picture. Convenience of access to the garage or the coal chute, etc. must be considered.

In other words the beauty of a place depends upon the harmony of all its parts.

and the service areas. The last two are often combined.

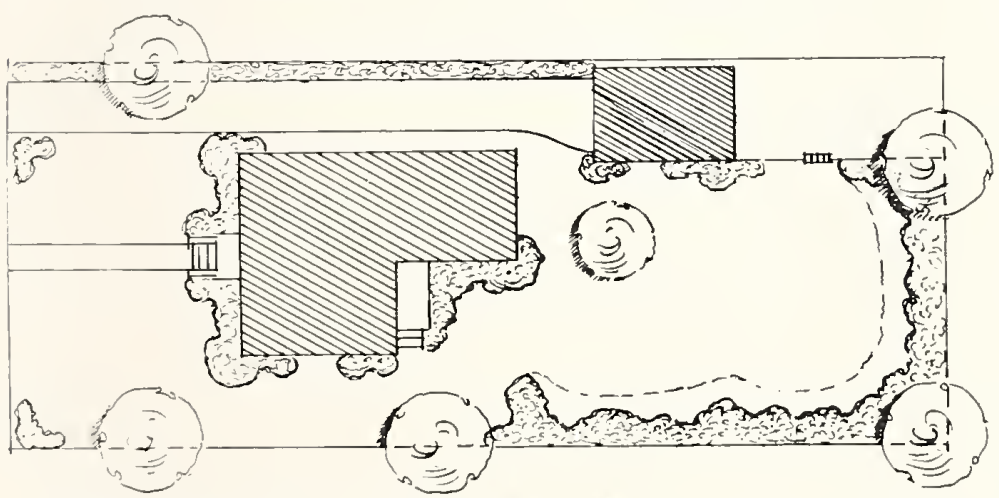

The Right and the Wrong Way!

These two illustrations prepared by our Landscape Architect illus trate the right and the wrong way to plan a yard. Alove-is shown an ideal plan with open expanse of lawn, with correct foundation plantings, border plantings screening the back yard, hedge edging the driveway, trees located for ideal shade, etc. Below-a perfect example of what not to do. Lawns cut up with flower beds and shrubs, trees incorrectly placed, foundations exposed by lack of planting, no screen at the rear of grounds, etc. Study the suggestions on this page and aid these faults in your grounds.

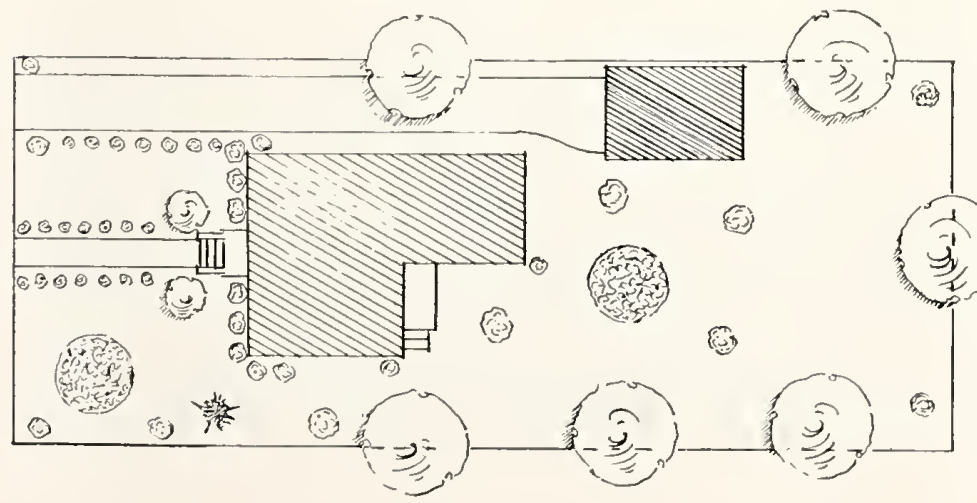

The public area or front yard serves as an entrance and foreground for the home and is usually best kept open, with trees located for framing the house or for shade and along the street, with possibly a hedge or shrub nasses at the corners. When the space in front is small the planting might better be confined to one or two trees and possibly a hedge. Placing shrubs or flower beds along the walk in the front lawn spoils the picture.

Plantings around the porch and the house will link the house to the grounds, the corners will be softened and the architectural features emphasized by the proper selection and arrangement of plant materials. If the house sits close to the ground, plantings are made only at the corners, at the entrances or along the porch. Otherwise there is need groring at the srowt. Whene corners, avoiaing straight nient placed so as to conform with the architectural features of the house Take into consideration the heights of shruls and ever creens when they reach mature growth so as to aroid greens when they reach
shutting off desirable views.

The space on the sides of the house may be so small that even a trimmed hedge will not be advisable. With larger ards, shrub masses are preferable to outline the property, divide the areas, to screen undesirable views, and to frame the grounds. They are less formal than a hedge an more attractive because of their variety in form, foliage,
color and season of bloom. The outlines of shrub plantings color and season of bloom. The outlines of shrub plantings heights should vary, to avoid straight, unbroken lines alons the top and along the edges are almost always preferable to single specimens.

The back yard often offers the greatest possibilities for pleasure and use. It serves the laundry, kitchen and the automobile, as well as recreational purposes, especially for chidren. There may be room also for a fruit, fower or shrubs and a tree or two may serve as a screen, to secur privacy, to protect from cold winds, to provide shade and at the same time present an attractive appearance. Here is the best place for flowers or roses, along the inside of fence, the sand pile belong.

In making your own plan it is well to follow this procedure. Using a scale of 8 to $20 \mathrm{ft}$. to the inch draw an proper locations the house and all existing trees, walks, garage, etc. Then you can put in plant materials following the principles stated above. The tables on page 8 will help to make your selection of shrubs.

Trees are usually located first, as backgrounds. They are placed well back of the house lines. To frame the house line of the house. For shade they go to the south and west of the house where they make the house cooler if they shade the ground between the trunk and the house rather than closer to the building. Along straight drive they should be set not over $35 \mathrm{ft}$. apart alternately and 10 to $15 \mathrm{ft}$ from the edge of the driveway. 


\section{Shrubs Lend Beauty and Finish to the Home}

CHRUBS are the most important ornamentals and give quickest results. They are invaluable as specimens; in groups or continuous borders; as screens against objectionable views or to secure privacy; as barriers or windbreaks; for flowering effects, for attractiveness of foliage or fruit. They have the greatest range of color and bloom, and increase in attractiveness, usefulness and value from year to year. They relieve the harshness where house and lawn meet and the sharpness of corners. The home nestles cozily in a nest of green, instead of springing suddenly from the lawn like a Jack-in-a-box.

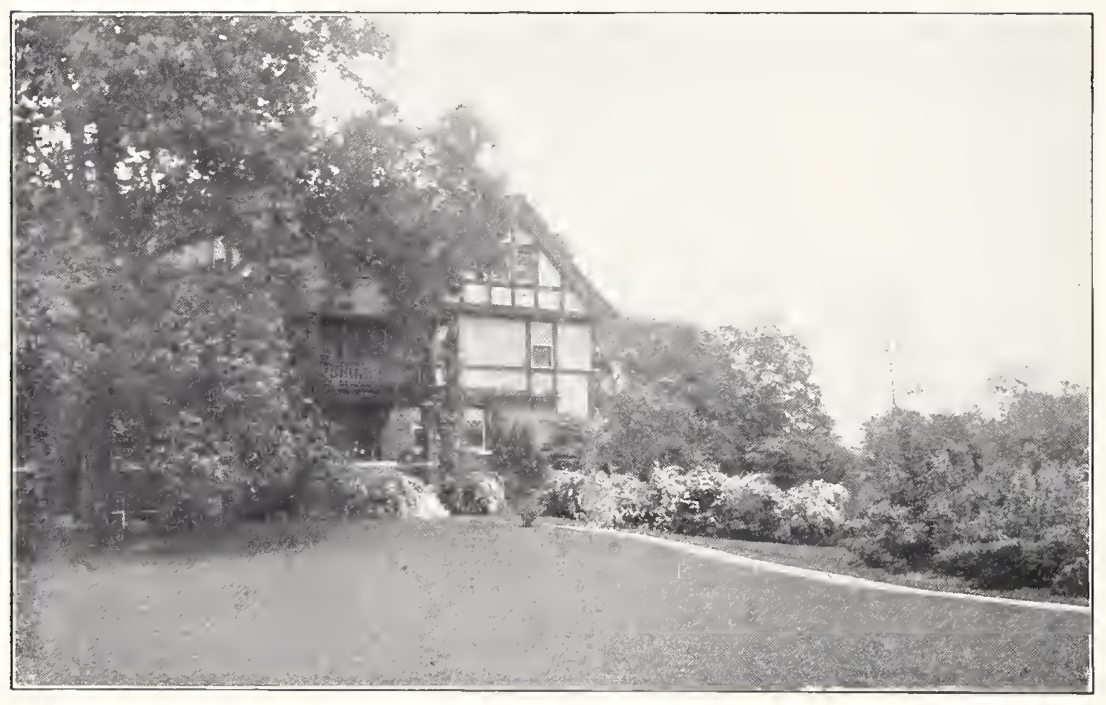

\section{Planting Distances}

One must look ahead and picture in mind the effect when plants are mature, generally about three years.

For planting in masses or groups, spacing varies with variety and effect required:

$\begin{array}{cc}\text { Close } & \text { Normal } \\ \text { Planting } & \text { Distance }\end{array}$

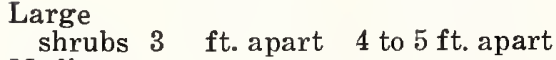
Medium

shrubs $2 \frac{1}{2} \mathrm{ft}$. apart 3 to $4 \mathrm{ft}$. apart Low

shrubs 2 ft. apart $2 \frac{1}{2} \mathrm{ft}$. apart

\section{Sizes of Shrubs}

In the purchase of nursery shrubs the average sized plants are better for transplanting than extremely large sizes. The latter have to be pruned and cut back severely and will require as much time to produce the desired effect as the average sized. Bear in mind that a small specimen of large growers like Althea or Mock Orange would be large for small growers like Crimson Spirea or Deutzia Gracilis.

\section{Planting Seasons} different seasons and varieties.
Most trees cannot be planted close to a house without robbing it of light and air, but tall shrubs, as a background for lower ones grouped around them, take off the sharpness of the corners, and let the sunshine stream in at the windows. The tall shrubs planted as a boundary make an effectual screen, and even on the larger estates an undergrowth of shrubbery is usually planted under the trees along the boundary. Shrubs are the natural complement of trees, filling in the gap between their branches and the ground, and it is possible to get homelike results from shrubs that it would take years to acquire with trees alone.

\section{Shrub Planting Suggestions}

If not ready to plant when stock arrives, handle as described on page 38 . Some "puddle" roots to prevent drying out from sun or wind. This is dipping roots in a molasseslike mixture of water and loamy soil.

Cut off bruised or broken roots smoothly

Set plants about same depth as they stood in nursery. In lighter soil plant a little deeper.

Pack good soil firmly about roots. Wet soil, if needed, when hole is partly filled. Then shortly after, unless ground is moist, shrubs should be watered, but in heavy soils too much water will injure the plants.

Leave soil level with surface of ground, except a ring of dirt may be left to form a basin for watering. should be dug at least a foot deep and the soil made loose and friable. Unless the soil contains plenty of fertility, well-rotted manure should be thoroughly mixed with the dirt, but never put in contact with the roots.

Plants can be moved with greatest success during their dormant period unless transplanted with a ball of earth about roots. Shrubs are dormant after buds have ripened and leaves have withered or dropped. This varies with

Within a radius of 300 miles of Kansas City, Mo., planting is done ordinarily through November up to the middle of December, and from about March 15 th to May 1st. Further South planting is done later in fall and during winter. The earlier planting is done when soil is in good condition the better will be the results.

\section{Pruning When Transplanted} Shrubs with heavy tops should have
at least one-third of the tops removed Some reduce the tops by removing entirely some canes, others partly cut back all tops. This pruning should be starts.

\section{Care of Shrubs and Trees}

Keep surface soil loose and moist and at even temperature by a 3 to 4inch mulch of manure or by keeping a dust mulch by repeated cultivations. During a drought, water thoroughly even though mulch is applied.

\section{Winter Protection}

It is alternate freezing and thawing by a heavy mulch of straw, leaves or manure put on after ground freezes. that does the damage. Prevent this

Here is al Effective Slrub Plantiug Binding the House to the Lawn, Softening Angles and Hiding the Low Foundation.

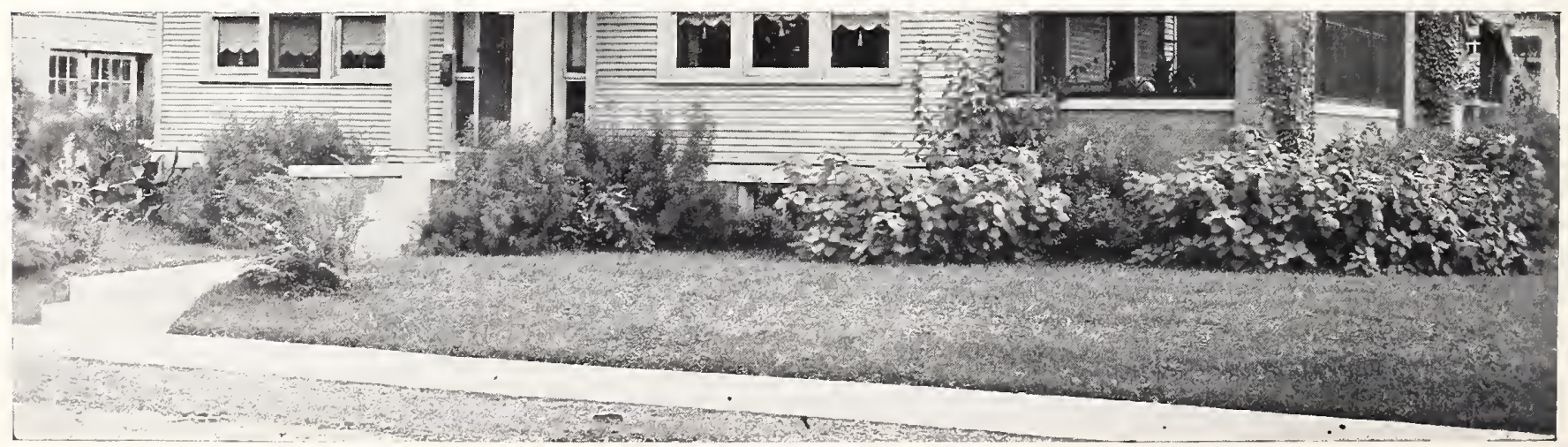




\section{Select the Right Shrubs For Your Grounds}

Season of bloom is for Southwest Missuuri and varies from year to year.

*Indicates endures partial shade.

\section{Tall Growing Shrubs}

\begin{tabular}{|c|c|c|c|c|c|}
\hline Variety & $\begin{array}{l}\text { Planting } \\
\text { Distance }\end{array}$ & $\begin{array}{l}\text { Mature } \\
\text { Height }\end{array}$ & $\begin{array}{l}\text { Color } \\
\text { Bloom }\end{array}$ & $\begin{array}{l}\text { Season } \\
\text { Bloom }\end{array}$ & Remarks \\
\hline $\begin{array}{l}\text { *Arrowwood............. } \\
\text { (Virburnum Dentatum) }\end{array}$ & $.4-5 \mathrm{ft} \ldots$ & $8-12 \mathrm{ft}$. & White.... & .May..... & $\begin{array}{l}\text { Blue-Black ber- } \\
\text { ries, Red foliage }\end{array}$ \\
\hline $\begin{array}{l}\text { *High Bush Cranberry...... } \\
\text { (Virburnum Opulus) }\end{array}$ & $4-5 \mathrm{ft}$. & $8-12 \mathrm{ft}$. & White... & May. & $\begin{array}{l}\text { Red berries and } \\
\text { foliage in fall. }\end{array}$ \\
\hline $\begin{array}{l}\text { *Japan Bush Honeysuckle... } \\
\text { (Loniceri Morowii) }\end{array}$ & $.4-5 \mathrm{ft}$. & $6-8 \mathrm{ft}$. & White. & April & $\begin{array}{l}\text { Red berries in } \\
\text { fall. }\end{array}$ \\
\hline$\underset{\text { (Syringa Vulgaris) }}{\text { Lilac, Common Purple.... }}$ & $.4-5 \mathrm{ft}$. & $8-12 \mathrm{ft}$. & Purple. & April..... & \\
\hline $\begin{array}{l}\text { *Mock O range................ } \\
\text { (Philadelphus Coronarius) }\end{array}$ & $.4-5 \mathrm{ft}$. & $8-12 \mathrm{ft}$. & White.... & May ..... & \\
\hline $\begin{array}{l}\text { *Privet, Ibota ................ } \\
\quad \text { (Ligustrum Ibota) }\end{array}$ & $.3-4 \mathrm{ft} .$. & $6-10 \mathrm{ft}$. & White. & May. & $\begin{array}{l}\text { Purplish foliage } \\
\text { and Blue-Black } \\
\text { berries in fall. }\end{array}$ \\
\hline
\end{tabular}

\section{Medium Growing for Foundation Planting}

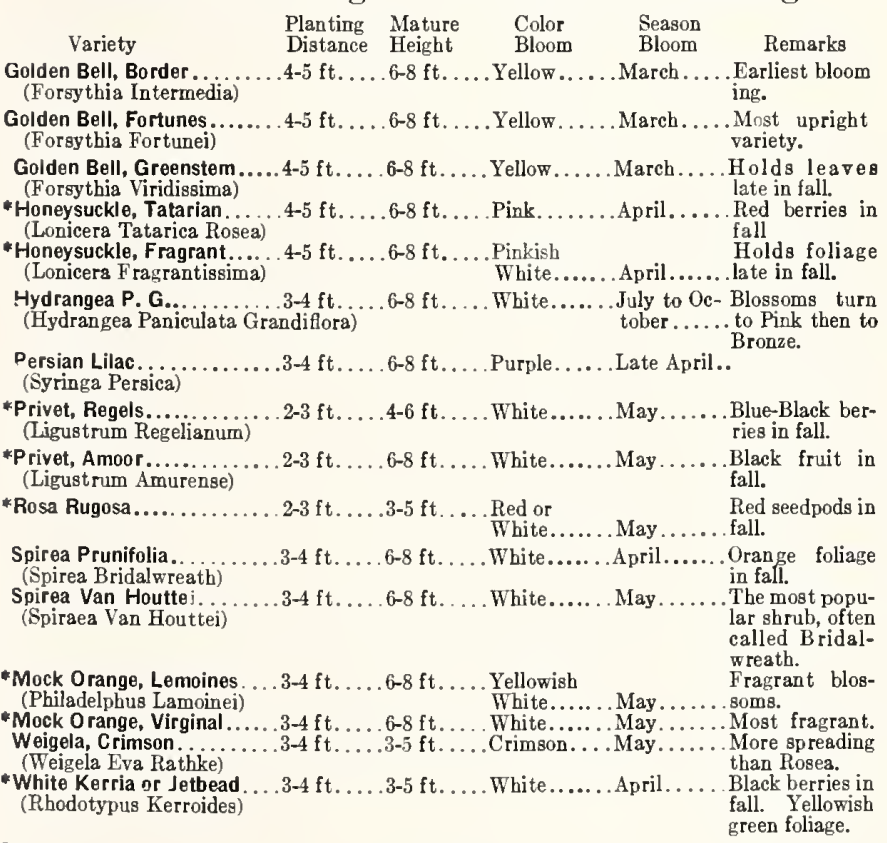

\section{POINTERS}

Use specimen plants sparingly.

Keep the center of lawn open.

Most shrubs make a more pleasing effect if planted in roups of three or more.

Elaborate, ostentatious and extravagant plantings are too ften the ruination of large and small estates.

Terraces should be designed by an expert. If unavoidable small lots, place the terrace close to the public walk. Steps

Don't whitewash your trees. It produces an artificial efect and serves no good purpose.

liake entrance walks direct. Curved walks in small areas asually

A good lawn is a prime necessity.

Horticultural curiosities can seldom be used effectively.

Poor soil will not produce good growth.

The taller shrubs need lower growers in front and the texture of the foliage should harmonize, avoiding the placing of shrubs with fine texture of foliage in front of those a coarser nature.

flawers bordered by trees, shrubs and fiews

"I can report that everything (22 Shrubs) sent me last year has done well-all living and healthy. If I can put any business your way, I certainly will."-Mr. Kenneth P. Beattie, Allegan County, Aichigan.

"What stock I bought from you last spring or rather last winter has simply done great. The spirea both red and white is wonderful; has a mighty fine growth, and was very full of bloom this, the first year, Couldn't possibly be better satisfied."-Mr. Roy McGhee, Ottawa County, oklahoma.

\section{Low Growing for Foundation Planting}

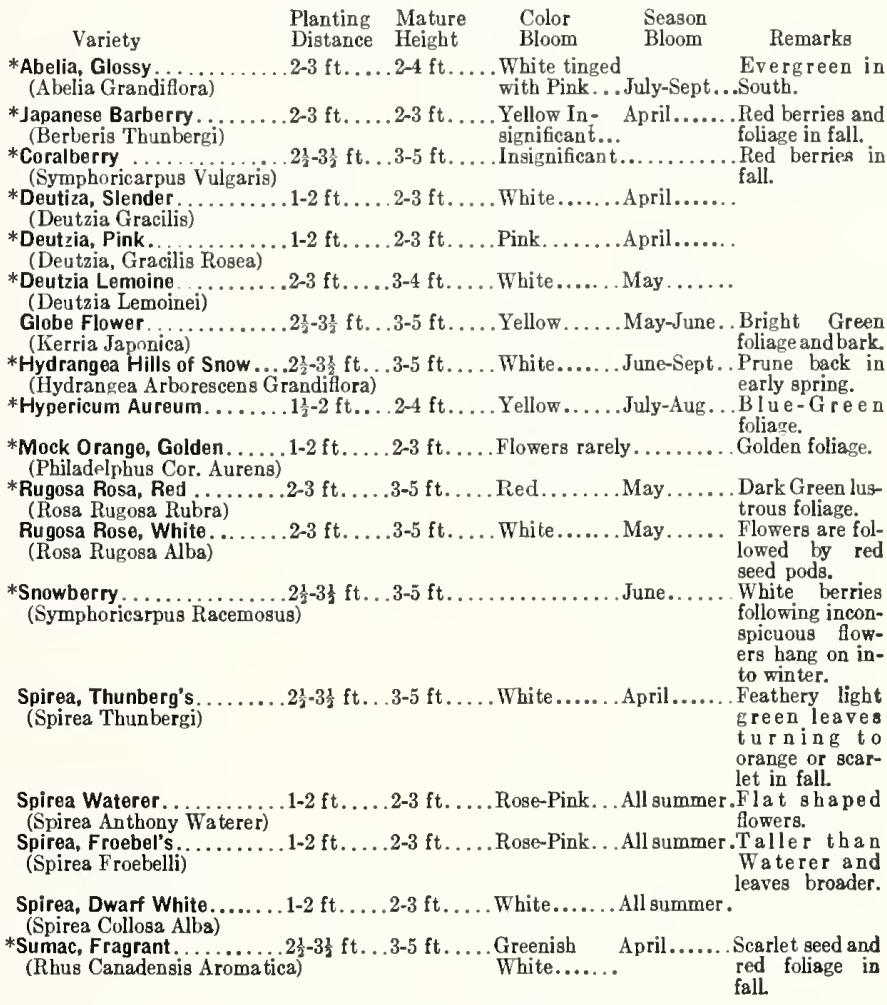

For Border Planting

(Also all Shrubs in Foundation Planting List.)

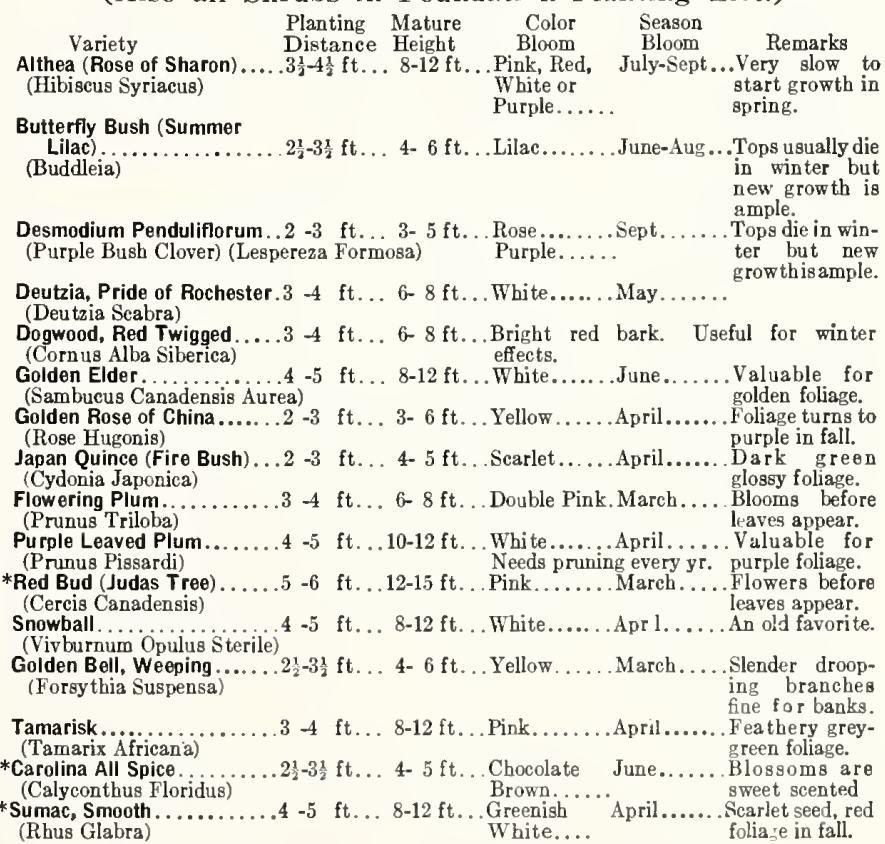

“The Most Beautiful I Ever Saw!"

"I reeeived the wonderful plan you outlined for my garden some time since and think it is one of the most beautiful I ever saw. Words fail me when I try to express my appreeiation for your splendid serviee."-Mrs. R. Lee, Ilo.

\section{"I Can Highly Recommend Your Stock"}

"The trees (10 Evergreens) you shipped me several months nä are doing exceptionally well and in very mueh pleased with them. I ean himhly reemmend your stoek and wish to thonk you for the prompt and eourteous way you handled my 


\section{Attractive Plantings Increase Property Values}

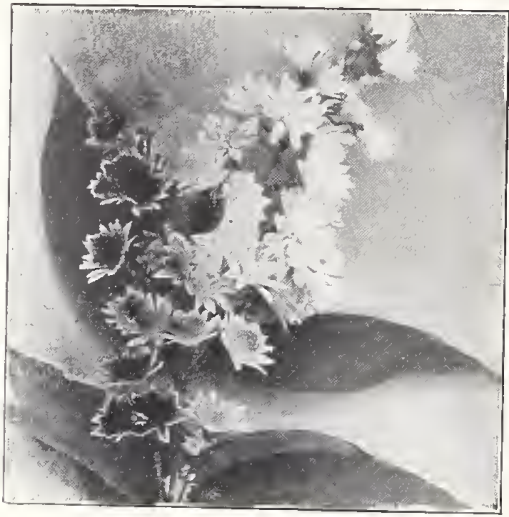

Deutria, Pride of Rochester

ABELIA GRANDIFLORA-A very pretty hhrub of unusual value. Mature flooms profusely rom July to september. Leaves glossy green turning coppery red in the fall; flowers tube-like, about an inch long, White blushed with pink; fragrant. Holds its foliage all winter as far north but hardy as far north as Kansas City.

ALMOND, FLoWERING (Anygalus) Grows 3 to $6 \mathrm{ft}$. tall. In late April the branches are covered with beautiful double, pink flowers before the leaves appear.

ALTHEA OR IROSE OF SHARON (Hibiscus Syrincus)-These popular shrubs have a compact, upright growth, attainin a height of 8 to $12 \mathrm{ft}$. Abundant flowers in white, pink or red, according to variety, appear in July to September when few other shrubs are in blossom. Valued as specimens, in shrub masses, as screens and for hedges, trimmed or untrimmed. They start growth slowly after transplanting, sometimes showing no signs of life for 30 days.

ARROWWOOD (Viburnum Dentatum) Attractive green leaves turning red in fall. white flowers in May followed by small black berries. Endures shade. dry or moist sill and grows 8 to $12 \mathrm{ft}$

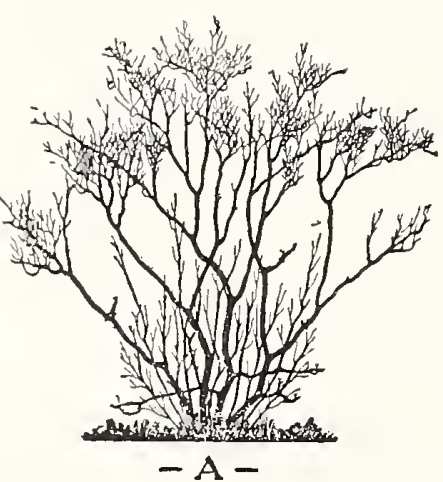

These illustrations are from "The Complete Garden" and are used by permission of the author, Mr. Albert D. Taylor.

Fig. A shows a large, overgrown shrub which is "leggy," i. e., presents a bare effect at the base. Flowers are borne in the top branches on the old wood.

Fig. B. The same shrub properly pruned to permit the new shoots to develop from the base of the shrub and to form a new top.
BARBERRY, JAPANESE ( Berberis Thunbergi) - One of the most valuable all-purpose shrubs, will grow in almost any soil, in sun or shade, dense growing; three to five feet; perfectly hardy. The leaves are small, green in early spring and summer, scarlet in fall int covered with scarlet berries in fall and winter. Its yellow flowers are inconspicuous. One of the best shrubs to plant against foundation of house or porch, in front of taller shrubs and best low hedge.

IBA I BERRY, RED-LEAVEI - Foliage reddish bronze in spring, brilliant red

BUSII CLoverk (Desmodium Penduliflorum)-Valuable for great profusion of pea-shaped, rose-purple flowers in september to late October. Grows 2 to in shrub masses or borders.

\section{DEUTZIA}

These well-known shrubs bloom profusely in spring or early summer, have good foliage and are very useful in groups, in mass plantings, and the dwarf arieties for foundation plantings.

eutha Gracis-A dense upright grower 2 to 3 ft. With abundant white flowers in April or early May. Very hardy, A partial shade.

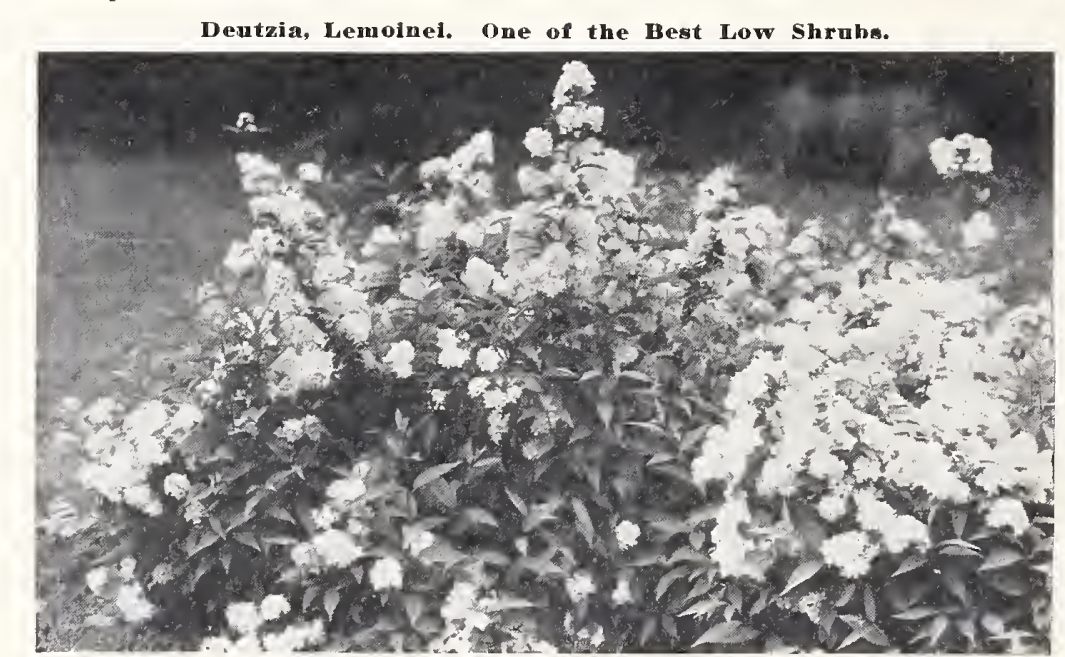

Deutzia Lemoinei-Hardy spreading grower 3 to $6 \mathrm{ft}$. with showier later White flowers

Deutzia, Pride of Rochester-A fast upright grower 6 to $8 \mathrm{ft}$. Double flowers, pink in bud, white when fully opened. BUTPERFLY BUSH (Buddein)-This shrub, 3 to $6 \mathrm{ft}$, is valued for its dark blue "li to " fl." ls valued for its dark in late July and August. in late July and August. It is usually and makes a quick bushy growth. CORALBERIRY Or INDIAN CURRANT (Symphoricarpus vulgaris)-This shrub grows 3 to 5 ft., has good foliage till late in fall: graceful, arching branches studded with small clusters of dark red berries that remain all winter. The small green flowers in August are insmall green flowers in August are insoil. Excellent for banks to prevent erosion.

DOGWOOD, SIBIEIAN (Comus Alba Sibiriea)-Valued especially for coralred stems. Some of older stems should be cut out each spring to encourage new growth that shows color best. It has white flowers in May and white berries into winter. It is fast growng, 6 to 8 ft., and is used for screen effects. Endures partial shade. Other varieties have grey, green and yellow bark or twigs. 


\section{Neosho Shrubs - Strong Rooted-Well Branched}

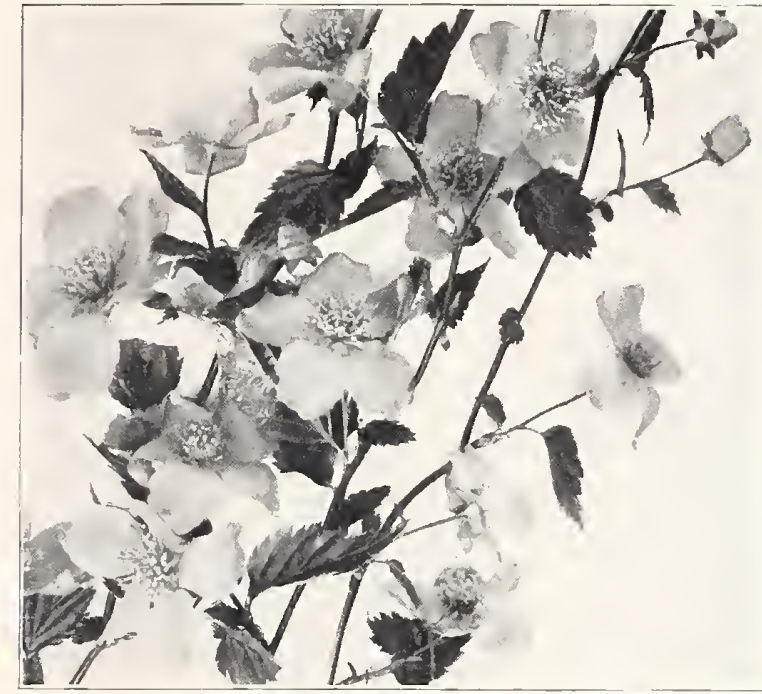

Iserria Japonical.

flowerixg PLUM (Prunus Triloba)Valued for its wealth of double pint April or early May.

GOLDEN BELL (Forsythia)-Golden Bells are hardy, fast growing shrub with good foliage which follows show yellow flowers.

The yellowish green branches are at tractive in winter. Grows 6 to $10 \mathrm{f}$ Used in mass and border plantings.

Border (Intermedia)-The tallest growing, earliest to bloom.

Fortunes (F. Fortunci)-The most up right growing, makes good hedge.

Green stenl (F, Viridissina)-Leaves turn purplish in autumn. Not as hardy as other Golden Bells.

Weeping (F. Suspensa)-G r a c e f $u$ l branches, long slender, drooping. Used to trallis.

GOLDEN ELDEIR (Sambuens Canadensis Aurea)-Valuable for golden foliage throughout the summer Grows \& to $12 \mathrm{ft}$

HIGH-RUSH CRANBERRY, AMERICAN (Viburnum Opulus Oxycoces)-Valuable for good foliage and red berries in fall. Bush is open, graceful, spreading, 8 to $12 \mathrm{ft}$. tall. White flowers

Hydrangea Paniculata Grandifora.

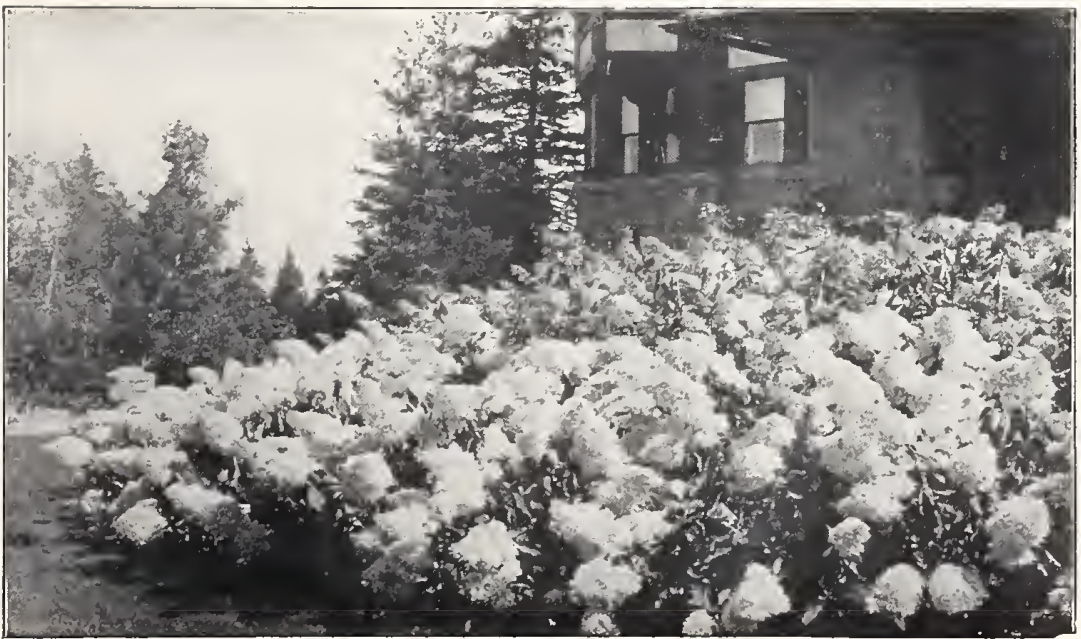

HONEYSUCKLE (LONICERA)

The Bush Honeysuckles are hardy, fast growing, have fine foliage and are useful in mass plantings. They endure partial shade.

Iorrows (L. Morrowi)-Its early white flowers are not showy but are followed by attractive red berries that hang broad and spreading.

l'ink Tartarian (L. Tartarica Rosea) Atractive pink flowers are followed by bright red berries. Taller gro Fragrant (1. Fragantissima)-Its pink ish-white flowers appear early in the its red beries and rark green leaves hang on into winter.

Hugonis Imose. a Chinese Briar ("The Golden Rose of China"), is a very at tractive shrub valuable as specimens and with other shrubs. Mature height up to $6 \mathrm{ft}$. and the same in width. branches of previous season's growth are covered with clear, yellow, single flowers. The abundant new growth the foliage turns to purple in the fall.

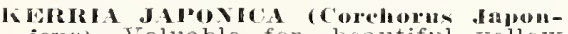
ieus) - Taluable for beautiful yellow fowers in May, for bright green rolitwigs in wintel. Grows 1 to $5 \mathrm{ft}$

\section{HYDRANGEA}

These deservedly popular hardy shrubs with showy white blossoms and long blooming season are used in groups, in masses with other shrubs and as specimens. Prune in late winter or early spring, severely for large flowers, lightly for greater quantity of

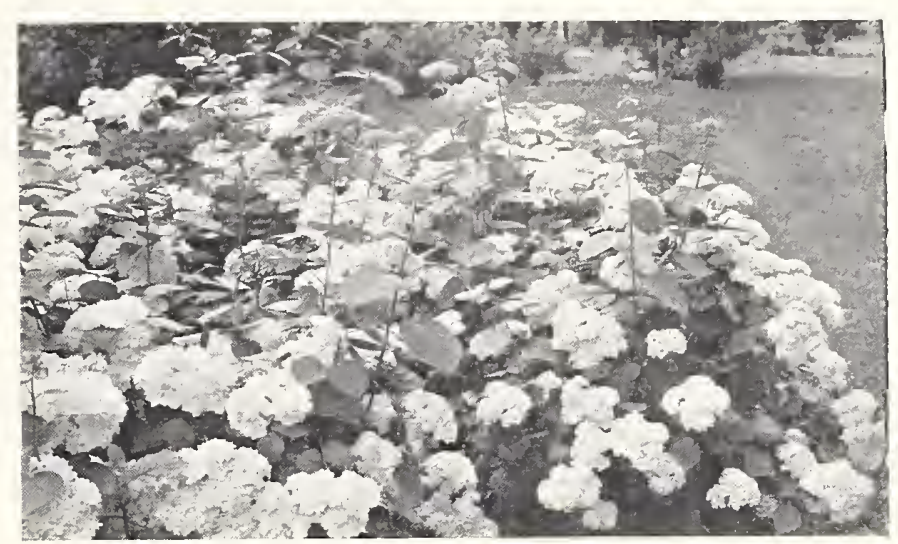

Hydrangeal Arborescens (Hills of Snow) 


\section{All Home Grounds Need Some Beautiful Shrubs}

MOCK OHA NGE (PIILADEIPHUS)

These attractive shrubs are justly popular for attractive foliage and creamy white fragrant blossoms. They are valuable as specimens, for screens and in shrub groups. Sometimes incorrectly shrub groups.

Sweet Iock Orange (Plitadelphus Coronarius - This is the well-known Mock Orange with fragrant white flowers in May Grows 8 to 12 ft. endures partial shade. Used for hedges in shady places.

Golden llock Orange (P. C. Anreus)Valuable for showy golden foliage and dwarf habit, grows 3 to 5 ft. Used for edging walks and for garden borders. Lemoines Mock orange - More graceful, leaves than Sweet or Common Mock Orange. White flowers in June are very fragrant.

Virzinal Hock orange (P. Virmininalis) - A new variety with large white a wers, very fragrant, in bloom over growth is conipact.

RUgOSA ROSLS (ROSA RUGOSA) Are exceptionally hardy, healthy and thrive under most difficult conditions of soil and climate. The branches are spiny and the leaves are shiny dark green, curiously wrinkled and not susry soil and partial sliade. The flowers come in May and are followed by red or orange-scarlet fruits which hang on into winter. Useful in groups or with other shrubs as for low unsheared hedges. Rowa lRugosa Alba-Has large, clear Ros: Rugosa Rulvra-Has large rosycrimson flowers. Mature height 3 to $5 \mathrm{ft}$.

conrid F. Meyer-Has large silvery pink, fragrant flowers, and grows 6 to $10 \mathrm{ft}$

F. J. Grootendorst-Red. Blooms spring on until frost.

PIIVETS (LIGUSTRUM)

Regels Privet (Lichustrum lbota Regeianun)-.-This shrub is useful for border planting and low-sheared edgings for walks and for garden borders. and to fill in with other shrubs which are more showy in flower or fruit. It has white flowers and blue-black berries.

Other varieties, see wase 13 under Hedges.

QUINCE, JAPAN (Cydonia Japonica)Attractive for scarlet-crimson flowers in April, and glossy green follage which hangs on well into fall. Used

SNOWBALL (Viburmum Opulus Sterile) - An old-time favorite with showy white flowers in large globular clusters in May or June; grows 8 to $12 \mathrm{ft}$.

Snowball (Viburnam Opulus Sterile).

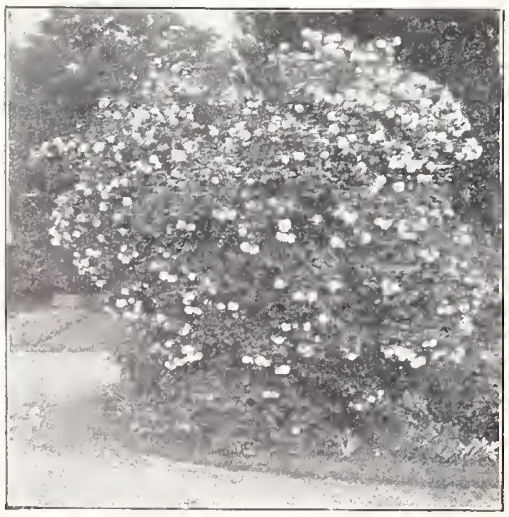

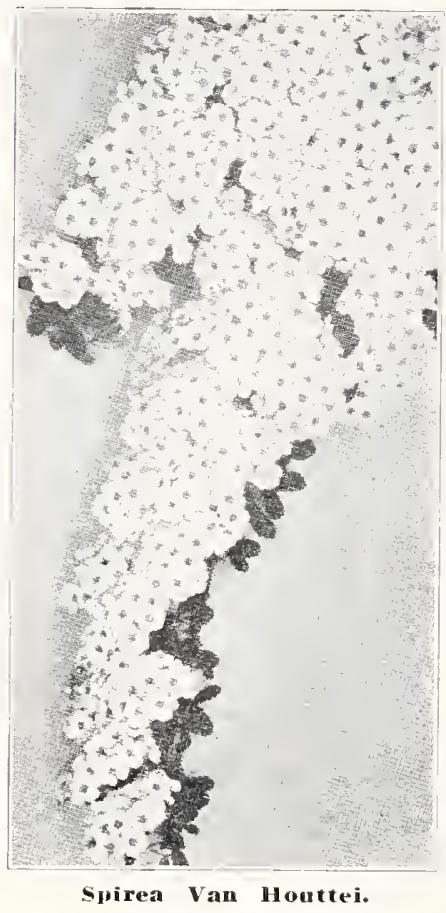

SNOWBERRY (Symphoricarpos Hacemosus) - Valuable for good foliage and for white berries into winter. Flower. white in July are inconspicuous. En dures partial shade; grows 3 to $6 \mathrm{ft}$ sheared hedge and on banks to prevent sheared

SUMAC, FRAGRANT (Rhus Canadensis Aromatica )-This low-spreading shrub about $3 \mathrm{ft}$. high, is valuable for good foliage turning to red in autumn, and for attractive red berries. Adapted to dry, rocky banks. Used also in border plantings. Leaves are fragrant when crushed.

SUMAC, SMOO'TH (Rhus Glabra)-At tractive fern-like foliage, with red leaves and fruit in fall. Grows 8 to $12 \mathrm{ft}$. Adapted for banks and rocky mass plantings.

TAMARISI, AFRICAN (Tamarix Afrlcana) - A graceful shrub or small tree. light pink flowers in May.

Weicrelir Rosea.

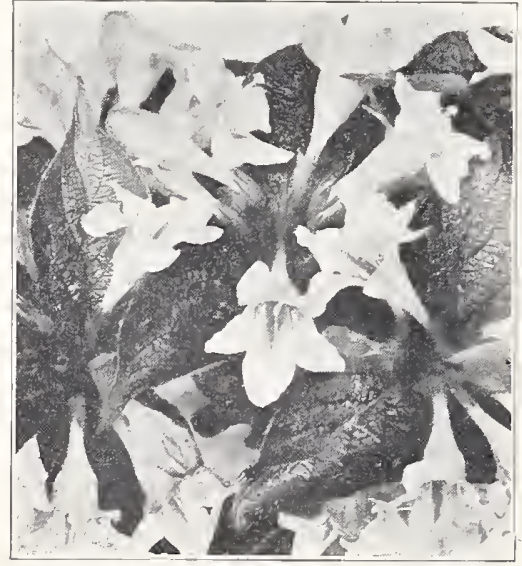

\section{Spirea (Spiraea)}

This is a large family of valuable shrubs varying in size, in habits of growth, and in color and season of bloom. duce their best development.

lillards Spirea (s. Billardi)-Upright grower, 6 to 8 ft., with pink Howers in spikes in midsummer.

Bridal Wreath (S. Prunifolia) - Often culliused with Van Houttei's spirea. A graceful shrub with white flowers in great profusion in April. The foliage is bright green turning orange-red in the fall. Grows 6 to 8 ft. The variety

Crimson Spirea (S. Bumalda Authony Waterer)-Flowers nearly all summer. bright red in flat clusters, narrow leaves, upright grower, 1 to 2 ft. Often used for edging walks and for
garden borders.

Drvarf White Spirea (S. Callowa Alba)The white flowers în flat clusters are borne nearly all summer. Grows 2 to 3 ft. Often used for edging walks and
for garden borders.

Dwarf Pink Spirea (S. Humalda)-A spreading bush 2 to $3 \mathrm{ft}$. tall with dark leaves and bright pink flowers in May and at intervals all summer.

Froebel's spirea (S. Frobeli)-Is one of the finest Spireas, similar to Anthony Waterer but somewhat taller and with broader leaves. Nearly all summer it is covered with bright crimson flower and the leaves turn purple in fall.

Thunberg's Spirea (S. Thunbergi)-Sometimes called Snow Garland-A spreading grower, 3 to $6 \mathrm{ft}$, with feathery light-green leaves and white blossoms in profusion in April. Foliage turns to orange-scarlet in fall.

V:In llouttei's Spirea (S. Vin Hontei)The most popular shrub. It is valuable as specimens, in groups, in border plantings, and for hedges. The branches are slender, drooping, covered with white flowers in April or early May, and the leaves are small and light green. It grows 6 to $8 \mathrm{ft}$. and is beauty.

WEIGELA, EVA RA'THIEE-Large trumpet-shaped crimson flowers in May and June. Bush is upright, but more spreading with age, grows 3 to $5 \mathrm{ft}$. tall. Very effective in groups and borders.

WELGELA ROSEA-Abundant, showy flowers vary from white to deep rose pink in May or June. Grows 6 to $8 \mathrm{ft}$. Very effective in groups or in mass or border plantings.

WHITE IKERRIA (Rhodotypus Kerroides)-Valuable for bright green foliage and white flowers in May and black seeds which hang on all winter. Endures shade; grows 3 to 5 ft. tall; hardy. Sometimes called Jetbead.

Rosa Rugosa-Alba.

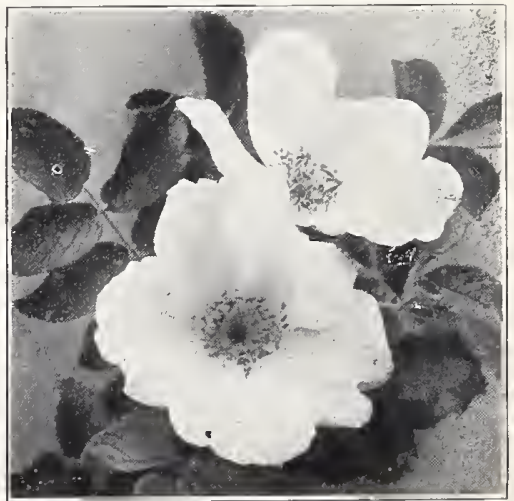




\section{A Good Hedge Adds Distinction to a Home}

Hedges are desirable for their beauty, for screens, for windbreaks and for barriers. They are also used effectively to outline flower gardens and for edging garden walks, pools, and planting beds. Some make a dense, solid growth and may be kept sheared in a formal shape. They are cheaper and more attractive than iron or picket fences that require painting.

\section{SHEARED HEDGES}

Japanese Barberry is the best low growing protective hedge. Its thorns keep out children and dogs but do not tear the clothes. Grows 3 to $4 \mathrm{ft}$., usually pruned lightly, plant 12 to 18 in. apart.

Privet is the most popular hedge plant and may be kept pruned at the desired height. They grow 8 to $12 \mathrm{ft}$. tall. Plant 8 to 12 in. apart. Set plants a few inches deeper than they were in the nursery and cut the tops off about 4 inches above the ground. Trim in spring before growth starts and lighter several times in summer, keeping the widest part at the base.

California Privet is the most attractive but is not very hardy. Amoor River Privet is very hardy, but loses its leaves earlier. Ibota is also very hardy.

"Plants Were Beyond My Expectation"

"The plants were in splendid shape whon received, and were far beyond my expectation in size and value,"Mrs. Cnsene Furale, Va.

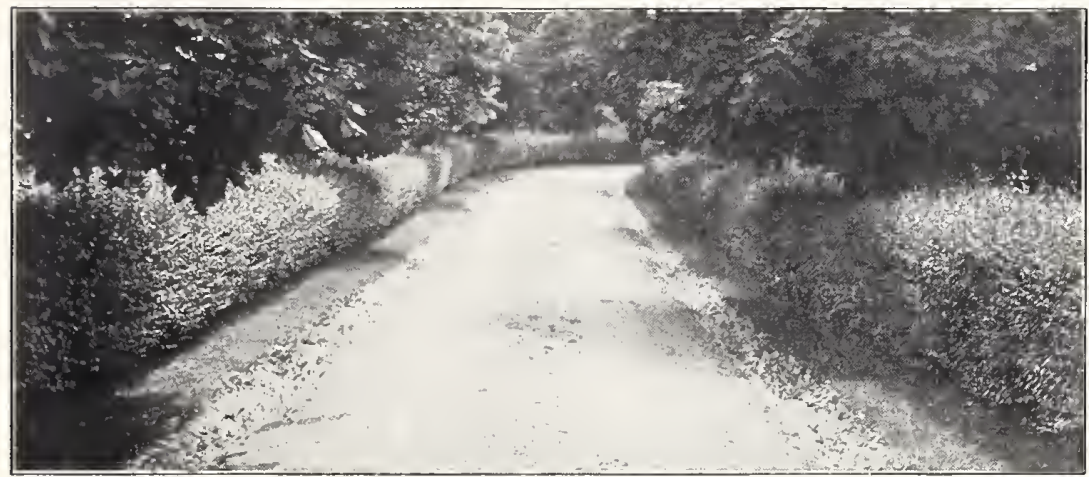

Privet. Most Widely Used for Ifedges. Use Amoor in Northern Loenlities

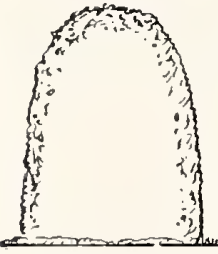

3

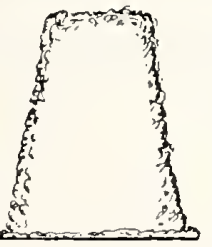

4

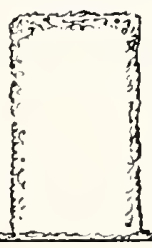

Theme are Correct Forms of Privet Hedge

FOR EDGINGS FOR WALKS AND DRIVES

Japanese Barberry. Deutzia Gracilis grows 2 to $3 \mathrm{ft}$, has white flowers in May, is not trimmed; plant 12 to $18 \mathrm{in}$. apart. Regel's Privet grows 3 to 6 ft., holds foliage into winter, is kept trimmed; plant 12 to 18 in. apart. Crimson Spirea and Dwarf White Spirea grow 1 to $2 \mathrm{ft}$. tall and blossom nearly all summer; plant 8 to 12 in. apart, untrimmed.

OTHER SHRUBS USED FOR HEDGES

The Golden Bells, Intermedia, Fortunei and Viridissima; Althea, Bush Cranberry, Snowball, Mock Orange, are planted 2 to $21 / 2 \mathrm{ft}$. apart. Hydrangeas and Conrad F. Meyer Rose are set 18 to 24 inches apart.

\section{TRIMMING HEDGE}

The Privet takes readily shears repeatedly through out the sunmer, trimming the new shoots, while they are tender and soft, the hedge can be trained into any of these formal sliapes.

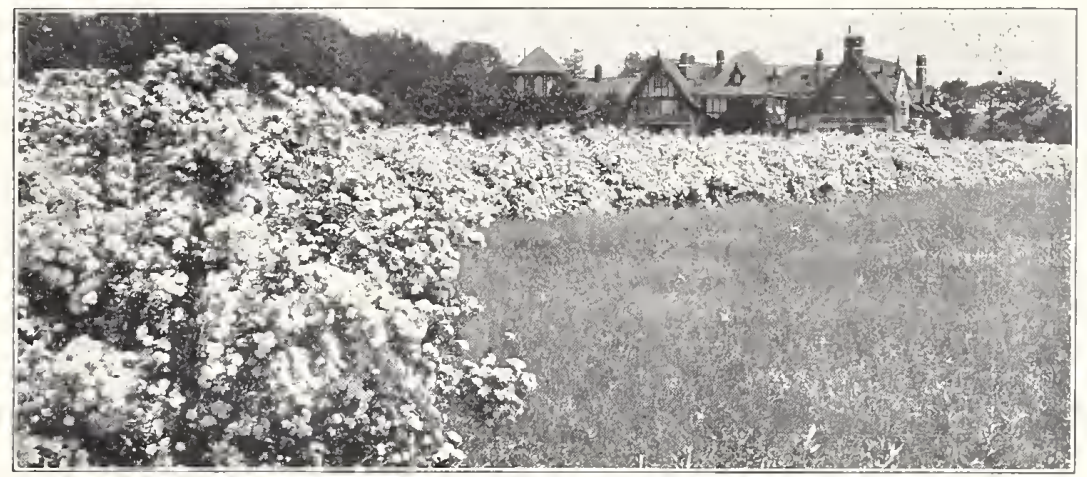

Spirea Van Houttei. Makes a Very Graeeful, Free-Growing Hedge

UNSHEARED HEDGES

Japanese Barberry and the following are most used for unsheared hedges. Spirea Van Houttei has graceful arching branches, attractive green foliage and is a mass of white flowers in April or early May. Grows 6 to $8 \mathrm{ft}$. Plant 18 to $24 \mathrm{in.}$ apart.

Rosa Rugosa-Very hardy, dense-growing shrub 4 to $5 \mathrm{ft}$. with shining dark green corrugated leaves, and red or white flowers followed by orange-red seed pods; endures partial shade; plant 15 to 18 in. apart.

Snowberry-Valuable for good foliage; white berries in late summer into winter; grows 3 to $5 \mathrm{ft}$.; endures partial shade; plant 15 to 18 in. apart.

Coralberry-Has good foliage and graceful arched branches with clusters of red berries all winter; grows 3 to $5 \mathrm{ft}$.; endures shade; plant 15 to 18 in. apart.

\section{HOW TO PLANT PRIVET}

Plants can be set eight inches to a foot apart in the row. Where a very dense hedge is desired, the plants can be set in a double row, each plant one foot and the rows also one foot apart. In groups or masses plant two to three feet apart.

In preparing the ground, dig a trench a foot or more deep and set the plants six to eight inches deeper in the ground than they were in the nursery. This will bring three or four of the lower branches below the surface, which after the first year, will make roots of their own, giving a dense solid growth.

Mound the dirt up six or eight inches above the level of the ground, to prevent the tops drying out. Rake this off when the buds start to open. Cut tops off $4 \mathrm{in}$. above ground. barberry (Japanese). The Best Low-Growing Protective Hedge

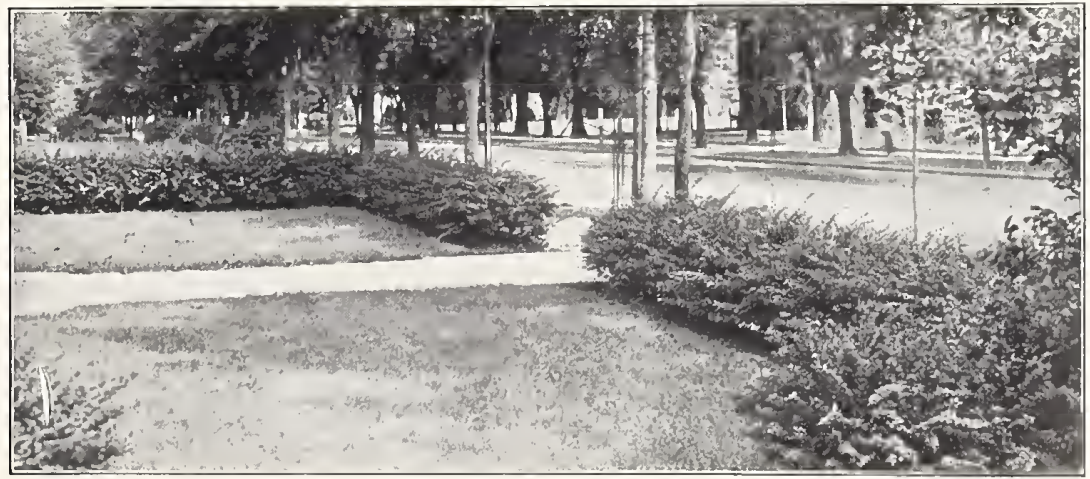




\section{Have Roses of Rarest Beauty This Summer}

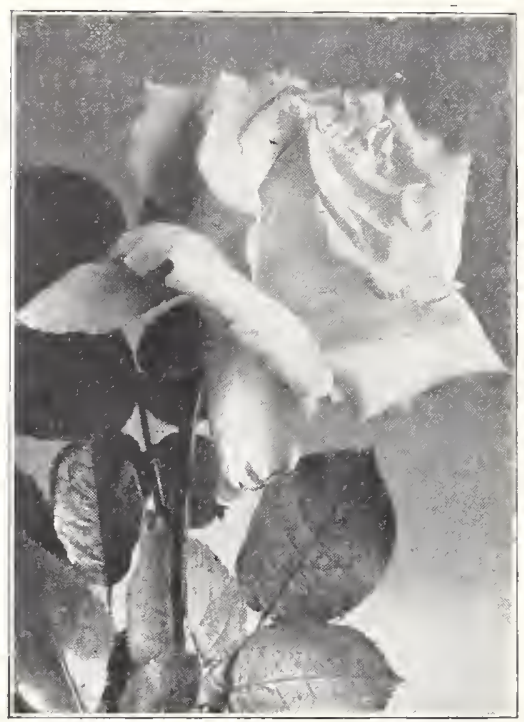

Mnman Cochet

\section{Hybrid Perpetual Roses}

This class do not require winter protection. They bloom very profusely in June and early July and again in the fall if properly pruned and fed.

MARSHALL P. WILDER-Deep dark red; large perfect flowers good for cutting; a vigorous grower; fragrant; hardy.

FRAU KARL DRUSCHKI- “Snow Queen." White American Beauty. Universally acclaimed the best white rose. A pure snow-white double flower, often 4 inches or more across and last a long time. Fine for cutting. Blooms almost continuously. Strong. vigorous grower, often $5 \mathrm{ft}$. or more in a season. It is best pruned moderately. Perfectly hardy.

GENERAL JACQUEMINOT-"General Jack" is one of the most popular red roses; bright crimson-scarlet, fragrant; perfectly hardy. Needs quite severe pruning. Good for cutting.

PAUL. NEYRON-Very large, fragrant, bright clear pink. Perfectly hardy and a strong grower.

Gruss an Teplitz

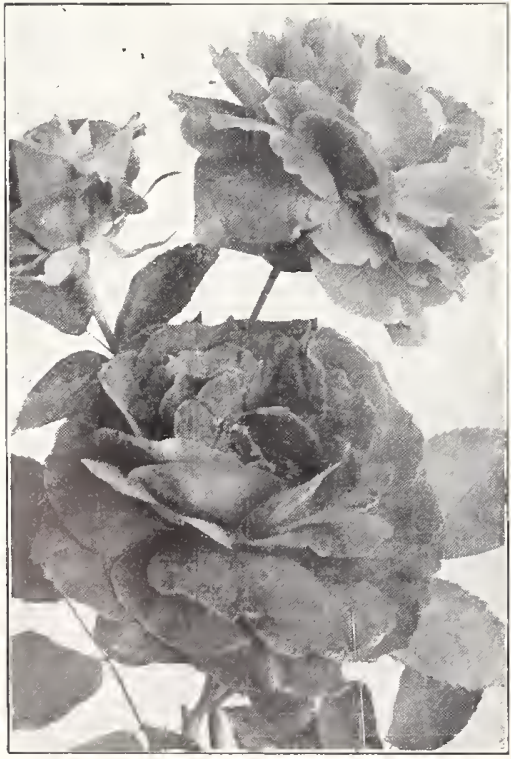

ding roses, to edge garden borders or walks, and in front of shrubbery masses. Can be transplanted to pots in fall to furnish winter blooms indoors. Prune lightly in late winter or early spring.

\section{Chinese Briar Roses}

HUGONIS-Is of shrub-like habit of growth and naturally forms symmetrical bushes about 6 feet high, and the same in diameter; plant with other shrubs or as single specimens. Its delicate yellow single flowers are produced on long arching sprays early in May, every branch of the previous season's growth becomes lined on both sides to the very tips with these attractive flowers and after it has finished flowering it remains an attractive decorative bush for the balance of the season. Perfectly hardy.

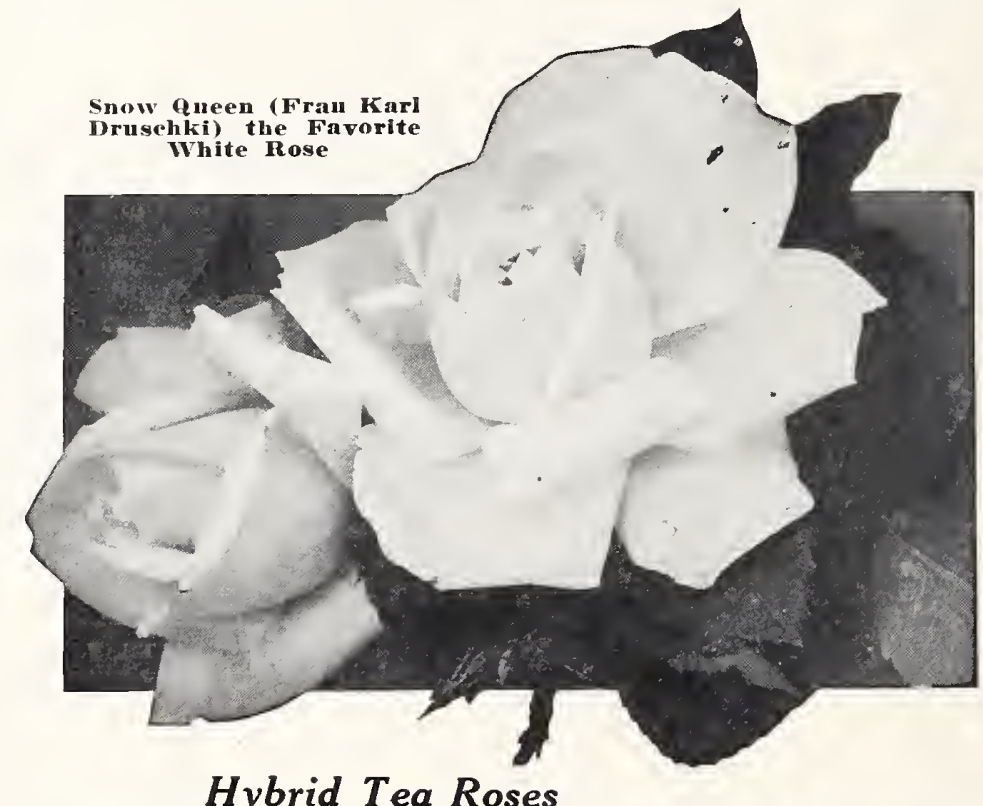

\section{Hybrid Tea Roses}

The Hybrid Tea Roses bloom more constantly than the Hybrid Perpetuals, but are not as hardy, requiring winter protection north of St. Louis.

GRUSS AN TEPLITZ-Dazzling scarlet; fragrant; one of the best deep red roses for continuous bloom; hardy.

KAISERIN AUGUSTA VICTORIA-Flowers are full double; creamy white; fragrant; continuous bloomer on long stems. Very hardy.

KILLARNEY-Clear, bright pink on long stems; excellent for cutting. Very hardy.

LA FRANCE-Light, silvery pink, very double and fragrant. Strong grower, moderate bloomer.

LOS ANGELES-Luminous flame-pink, toned coral, shaded translucent gold at base of petals.

MADAME CAROLINE TESTOUT-Large size, bright pink, fragrant. Not a prolific bloomer, but very hardy.

OPHELIA-Deep yellow on opening but quickly fades lighter except in the center. Tall but not bushy plant; dependable but not profuse bloomer. Quite hardy. Excellent for cut flowers.

RADIANCE-One of the best and most popular pink roses. Grows bushy and tall, is one of the hardiest, resistant to disease and a liberal bloomer.

RED RADIANCE-A brilliant crimson. In other respects the same as Radiance.

SUNBURST-Bronze-yellow; fine for cutting. Growth low and somewhat spreading. Has few thorns. 


\section{Good Plants Plus Good Care Bring Rich Rewards}

\section{Hardy Rugosa Roses Thrive Everywhere}

The hardiest of all roses, very thorny, with shining, dark green, very wrinkled leaves; will grow almost anywhere, even on barren, wind-swept slopes and seashore sand. Seldom attacked by insects or diseases.

Excellent for hedges, for planting with other shrubs or as specimens. They require little attention except thinning out the dead wood and keeping them in bounds.

CONRAD F. MEYER-Large, fragrant, silvery pink flowers, in June and occasional blooms thereafter. Should be planted not less than $3 \mathrm{ft}$. apart. Its 6 to $10 \mathrm{ft}$. growth may be trained over an archway or against a building.

F. J. GROOTENDORST-Red, true rugosa foliage. Blooms bright crimson, in clusters, produced from early spring to frost. Strong but compact, dwarfish grower. Particularly suitable for hedging and mass planting.

ROSA RUGOSA ALBA-Large, white, fine-petaled flower, followed by attractive orange-red seed pods; a dense grower, 3 to $5 \mathrm{ft}$. tall.

ROSA RUGOSA RUBRA-Large, very fragrant, bright pink to deep carmine flowers, followed by orange-red seed pods. A dense grower, 3 to $5 \mathrm{ft}$. tall.

\section{Climbing Roses}

They are very hardy, resistant to insects and disease, vigorous in growth, making canes $10 \mathrm{ft}$. or more in height, and adaptable to many uses-trained on a trellis, a porch, a house, over banks, on stakes 4 to $8 \mathrm{ft}$. high, or even allowed to grow at will as a rambling bush.

AMERICAN PILLAR-A single flowering variety of great beauty. The flowers are of large size, 3 or 4 inches across, of a lovely shade of pink with a clear white eye and cluster of yellow stamens. These flowers are borne in immense bunches, and a large plant in full bloom is a sight not easily forgotten.

IIARY WALLACE-Pillar rose type. Well formed, semidouble flowers of a bright clear rose-pink with salmon base to the petals; flowers large, generally exceeding four inches in diameter; very free flowering; hardy.

CLIMBING AMERICAN BEAUTY-Rose crimson flowers in profusion suitable for cutting. A vigorous grower, very free from attacks of insects and disease. Older canes should be pruned out each year.

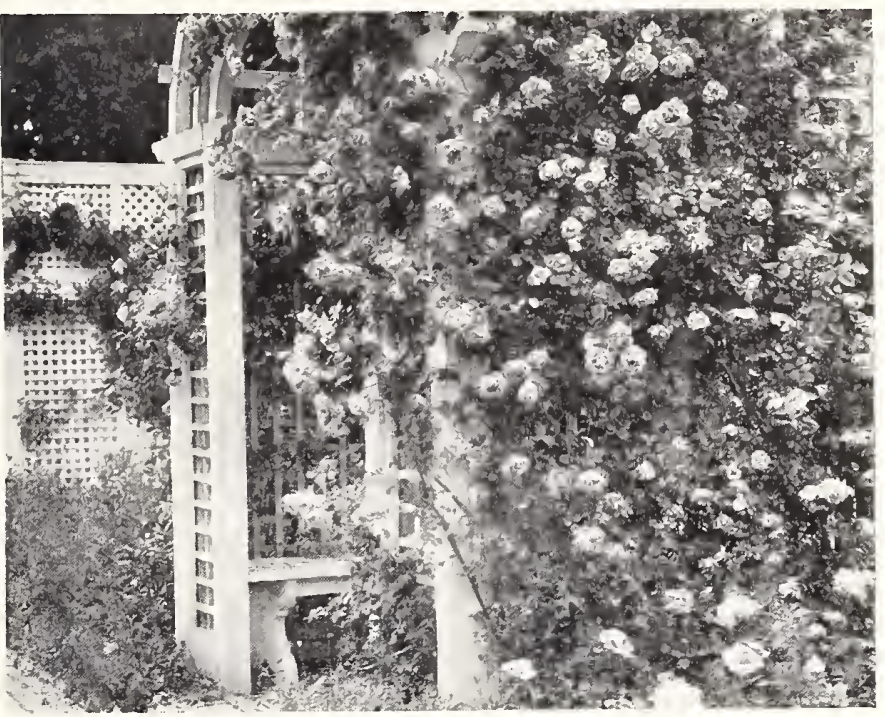

Climbing American Beauty lose.

DR. VAN FLEET-Pure apple-blossom-pink flowers, good for cutting. A very profuse bloomer.

SILVER MOON-Large, silvery white, with yellow stamens. Foliage glossy, dark green; very vigorous grower.

DOROTHY PERKINS-Double, shell-pink flowers in clusters; vigorous and dependable.

EXCELSA-Sometimes called "Red Dorothy Perkins"; far superior to the old Crimson Rambler. Radiant, bloodred double flowers in large clusters. Very vigorous and quite free from attacks of insects and disease.

GARDENIA-The buds are bright yellow, the flowers creamy with yellow centers; early, in small sprays; fragrant.

PAULS SCARLET CLIMBER-Bright, vivid scarlet double flowers in clusters of three to six. No other rose can compare with it in brilliancy of color.

\section{Study the Simple D \\ of course you want roses blooming} in your garden next summer. You can have them if you will do your part in properly planting and caring for the Roses we send you.

First. Select a location where the roses will have at least a half day's sunlight and where they will not have to compete with the roots of trees for food. Lay out the bed with the bushes about 10 inches from the edge of the beds and spaced $2 \frac{1}{2}$ to $3 \mathrm{ft}$. apart for the larger growers like the Hybrid Perpetuals, and 18 to 24 in. for Hybrid Teas. For a single row a bed about 18 inches wide is sufficient.

Second. Send us your order for our first class 2-yr. field grown plants.

Third. Prepare the beds at once. Dig the bed 18 to 24 inches deep, putting the good top soil to one side. If your soil is mostly clay, dig the hed 6 inches deeper and put a 6 inch layer of stones or crushed rock in the bottom. Fill in with good soil thoroughly mixed with well rotted manure. If your soil is quite gravelly or sandy, mix in some clay. One-third each of top soil, clay and rotted manure is a good mixture.

Fourth. When your roses arrive if you cannot plant at once, "heel" them in, i. e., dig a trench and spread out the bushes and cover them root and top. rections for a Succ
Pack the dirt closely about the root and mound up the dirt 6 inches or more above the surface of the ground. They will then be ready to transplant when the weather is favorable.

Fifth. Planting and Mulching-Do not expose the roots to drying sun or winds. Keep them well covered with damp earth, moss or bags. Dig a generous hole. Set budded roses so that the point where the bud was inserted is one to two inches below the surface. Set own-root roses, including the Climbers, about an inch deeper than they stood in the nursery. Spread the roots carefully and tamp the dirt firmly around them. The tops will be cut back to not more than a foot before shipment. Water thoroughly if the ground is dry.

After Care. Keep the ground cultivated lightly, or use a mulch of peat moss or strawy manure. Feed the plants with bone meal worked into the soil or with liquid manure. Soak the ground thoroughly whenever the surface becomes quite dry. Prune in early spring. With strong growing varieties cut back the larger canes to five or six buds or eyes, the weaker canes to 3 or 4 buds. With the smaller growing varieties leave 3 to 4 buds on strong canes and 2 to 3 on weak growths.
Rose Garden

Climbing roses are pruned just after blooming, cutting out old wood according to growth and tie up the new canes to the position desired.

Winter Protection. Before the ground freezes put a mound of dirt about 6 inches high around each plant. After freezing, cover with dry leaves or heavy litter of manure and straw. Remove this soil and mulch in the spring.

Disease and Insect Control. To prevent mildew and black-spot, dust every week or two as soon as the leaves put forth with 9 parts dusting sulphur and 1 part of powdered lead arsenate. To kill plant lice or aphis, spray with a nicotine solution like Black-Leaf-40.

\section{"Never Saw Nicer Roses"}

"My vines and roses sure are nice. They are blooming this summer, and I don't think I ever saw any nicer roses than they are."-Fannie King, Murray Co., Okla.

\section{"Such Grand Roses"}

"I never had such grand looking roses before, and we'll be singing your praises every time we bury our 'noses' in them to smell the fragrance, in which I think roses excel all else."-Myrtle II. Stafford, Washington Co., Ark. 


\section{Beautiful Grounds Need These Plant Materials \\ Easily Grown Spring Bulbs \\ Hardy Perennial Plants}

Plant after frosts are over, in rich, well-drained soil. It helps to set each bulb on a handful of sand. Don't put manure in contact with bulbs.

CANNAS are most effective when used in masses with varieties of a kind grouped together, tall growers at the back, lower growers in front. Set 4 to 5 inches deep, 18 to 24 inches apart. For a round bed $7 \mathrm{ft}$. in diameter, set 18 inches apart, one in the center, six in the inside row and twelve in the outside row.

GLADIOLUS are easily grown, have a great range of color and as cut flowers keep for a week. They mature in about 90 days so that successive plantings provide blooms from July till frost. Plant in beds, in rows, or in clumps among perennials. Plant 2 to 4 inches apart, 4 to 5 inches deep in heavy soil and 7 to 8 inches deep in light soil.

DAHLIAS should be set about 4 inches deep and 4 to $\bar{x}$ ft. apart. When they have made their first leaves cut away all but one or possibly two strong shoots. When a foot high tie to a stake. Side shoots can be made to put forth by pinching off the top.

\section{Spring Brilliance with Iris}

Sometimes called Hardy Orchids because of their exquisite coloring.

Few plants will give such satisfaction at very little cost. Iris thrive in nearly any location and with the least care. These beautiful flowers may be enjoyed over a long period. Different varieties of Iris Germanica bloom in our climate from mid-April until May and are followed by Japanese sorts (Iris Kaempferi) later into June.

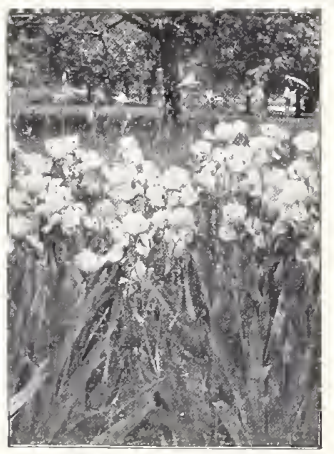

For varieties see price list.

May be planted in the spring but give better results and more bloom first season if set in the fall from August until first frost.

Put the crown of the root about two inches below the surface. For planting along borders or in masses they are spaced 8 to 10 inches apart. If planted in rows set 18 inches apart in rows 3 feet wide.

\section{Bulbs for Fall Planting}

Plant in October or November in deep, well-drained rich soil. Hyacinths, Tulips, Narcissus, Jonquils, are set 4 to 6 inches apart. Cover Tulips 4 inches deep; other kinds 5 inches. Put a handful of sand under each bulb when planting. Mulch with straw or leaves 4 to 6 in. after ground is frozen. Remove mulch carefully in spring before warm weather.

\section{Other Hardy Perennials}

LILY OF THE VALLEY (COnvalaria Majalis)-Plant in spring in partial shade.

GOLD BANDED LILY (Liliam Atratum)-Plant in spring, 18 in. apart, 6 in. deep. Flowers in July and August.

MADONNA LILF (Lilium Candidum)-Plant in fall, 1 in. apart, 4 in, deep. Flowers June 15 th to July 15 th

JAPANESE IRIS (Iris Kuempferi)-Various colors, June 15 to July 15 th. 2 to $3 \mathrm{ft}$. stalls. Plant 12 to 18 inches apart,
These plants will bloom for you abundantly the first summer and in succeeding years without replanting, although some varieties need to be taken up and the roots divided after several years.

Plant in masses bordering driveways, fences, or the lawn; along shrub borders, or in the garden. Our Landscape Department will gladly help you plan your plantings upon request.

It rays to mix in thoroughly well-rotted manure or bone meal in good soil that has been deeply dug. The ground should be kept well stirred and soaked with water occasionally during the hot dry weather. Apply a covering of manure in the fall and mix it into the soil in the spring.

In northern states, varieties that bloom late in the season are better transplanted in the spring.

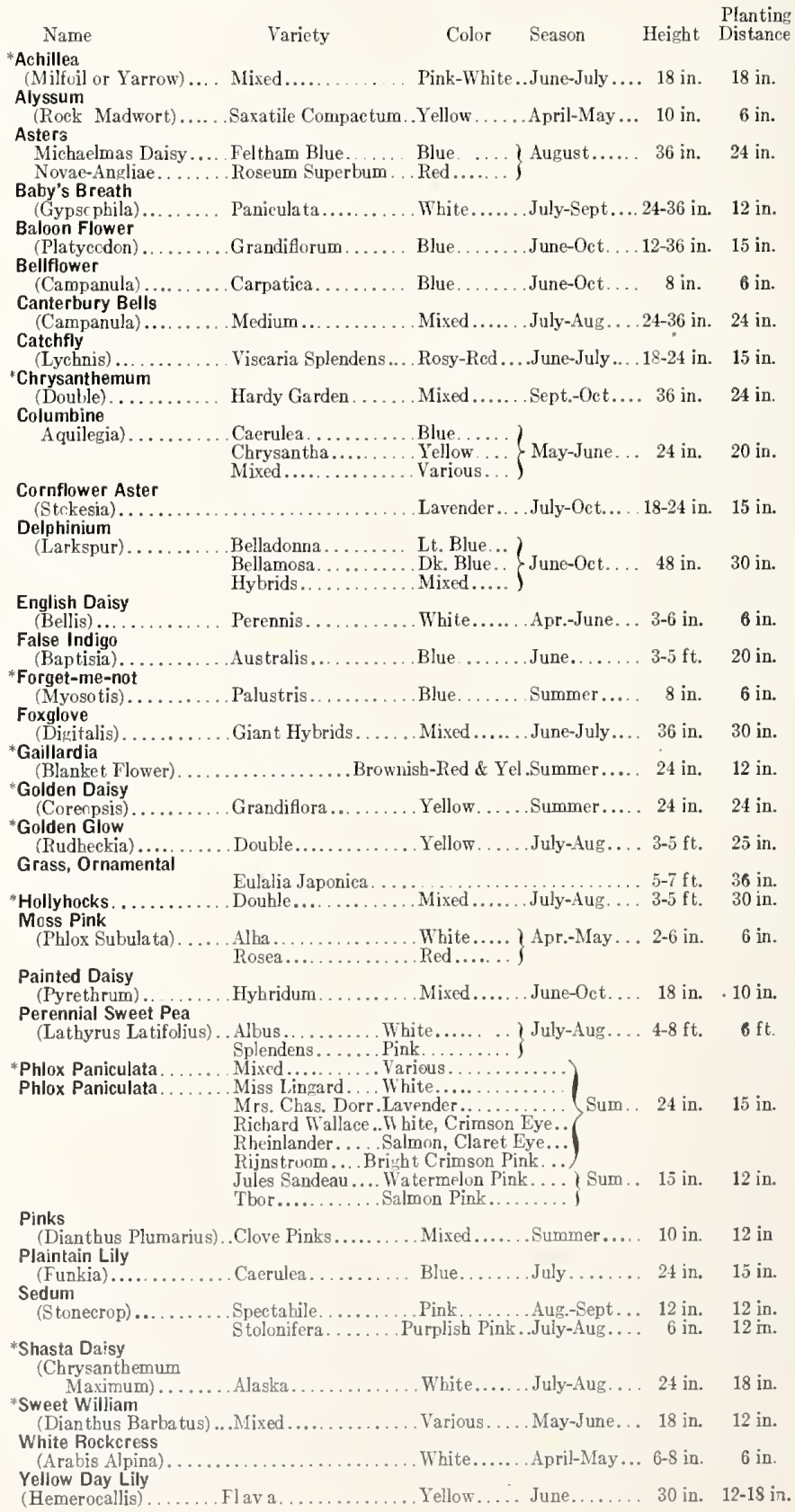




\section{Climbing Vines for Porches, Arbors or Walls}

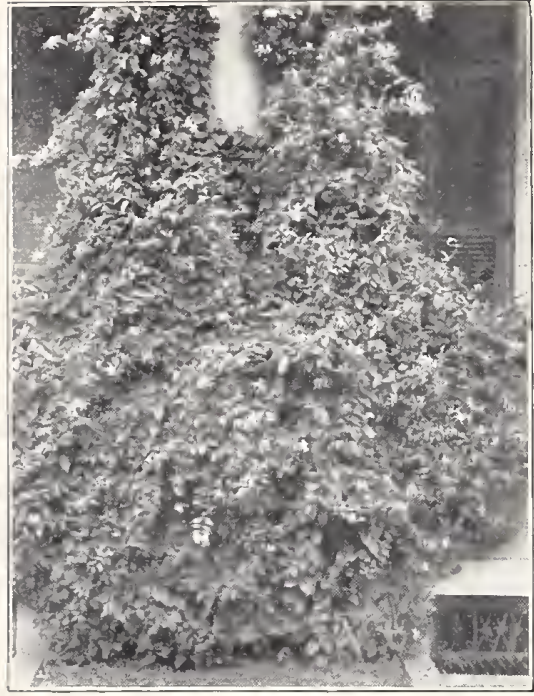

Hall's Honeysuekle-
A beantifui climber

BOSTON IVY (Ampelopsis Tricuspidata Veitchi)Bright attractive foliage turning to crimson in the fall; clings firmly even to smooth surfaces; hardy.

VIRGINIA CREEPER (America Ivy) (Ampelopsis Quinquefolia)-Beautiful, Iarge five-lobed leaves turning brilliant crimson in fall, contrasting handsomely with its blue berries.

ENGIISH IVY (Hedera Helix)-Has attractive evergreen leaves, waxy, dark green. Clings to walls or trees. Not hardy north. Does best on north or east side of house.

CLEMATIS, JAPANESE (C. Paniculata) - Bright foliage with countless little star-shaped white flowers, very fragrant; blooms in August and September. Support on trellis; grows to fifteen feet.

CLEMATIS, JACKMANNI-Violet-purple blooms in July and August.

HONEYSUCKLE, HALL'S (Lonicera Japonica Halliana)-Shiny green foliage; pure white, trumpet shaped flowers with sweet perfume; used to cover fences, embankments, arbors, etc. Blooms in late fall. Hardy. Thrives in heavy soil. Endures shade.

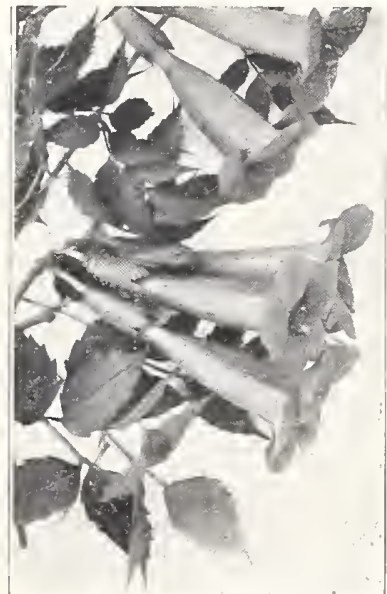

Trumbet Viuc (Bignonia Radicans)

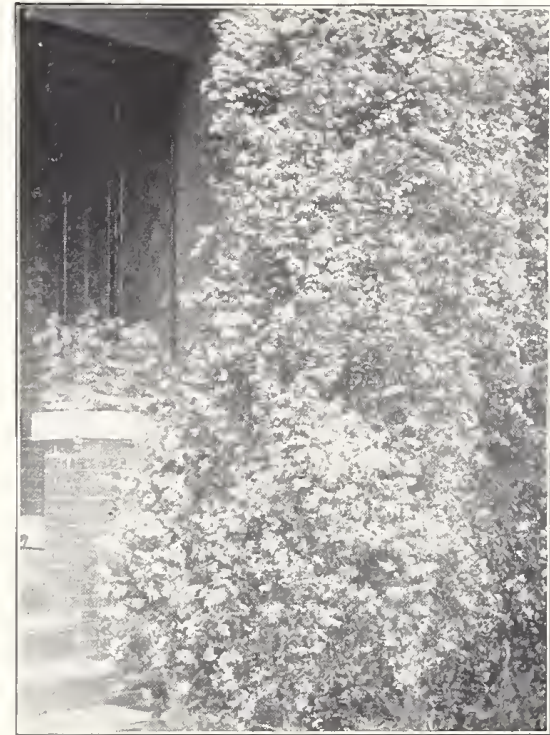

Japanese Clemati

TRUMPET FLOWER (Bignonia Radicans) - L o n g, trumpetshaped orange-scarlet flowers, beautiful light green foliage. Es pecially good for covering walls, fences and embankments. Blooms in July and August.

WISTERIA, JAPANESE-Beautiful foliage, long clusters of pearshaped, purple flowers; makes a heavy vine; grows very tall.

H O N E Y U C K L E, SCARLET TRUMPET (Lonicera Sempervirens); orange-scarlet flowers $1 \frac{1}{2}$ to 2 inches long in summer.

"I Never Saw Finer Stock!" "I wish to say I never saw finer stoek (1:2 slirubs). My gardener Douglas J, Parles, N. Y'.

\section{Glorious Peonies-Easy to Grow}

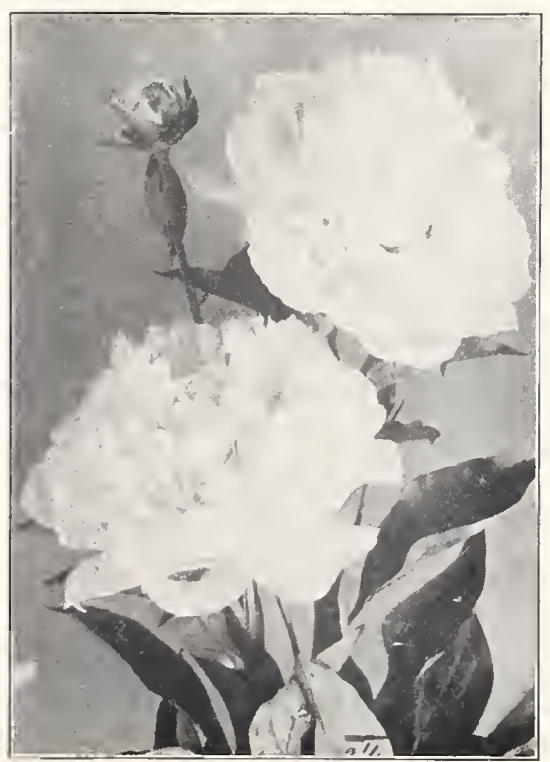

Iomule IBlossoms

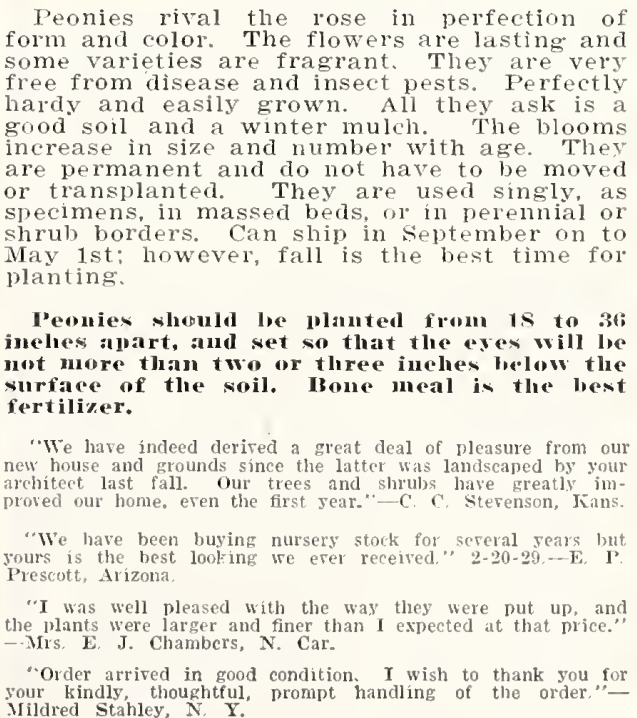

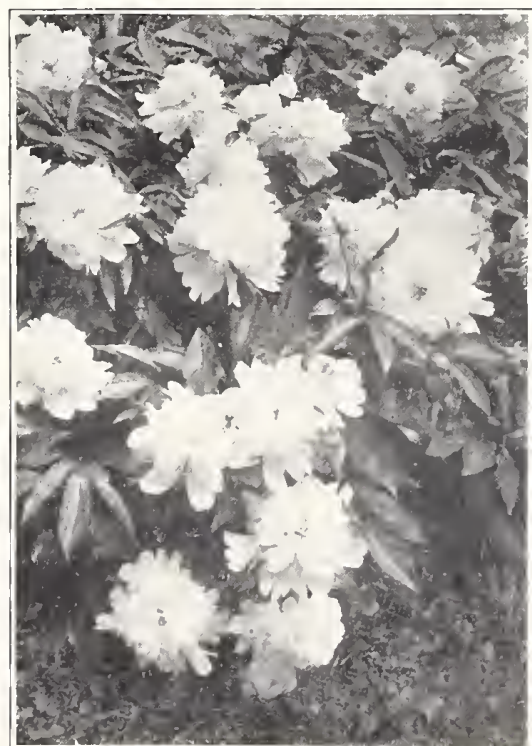




\section{Evergreens for Distinctive Effects}

GVERGREENS never drop their foliage and hence do not go into a dormant condition. Necessarily they must be transplanted with a ball of earth around the roots. Frequent transplantings with root prunings are necessary in the nursery row to develop a mass of fibrous feeding roots within the ball. Neosho evergreens are carefully hand dug, the balls of earth wrapped with burlap.

The specimens offered below are graded by height measuring from the level of the ground to the tip of the specimen. In a few instances they are offered by spread. Our guarantee is to deliver good, thrifty specimens that will meet your approval on arrival. There is positively no guarantee as to growth.

\section{When to Plant Evergreens}

The two seasons for planting, fall and spring, are equally satisfactory, the fall season running from September 15th into December, spring from early March into June. These dates may vary slightly with different seasons, and also with location, according to whether one is situated in the extreme northern or southern zones.

\section{Adaptability of Evergreens}

Most all Evergreens do well in both sun and shade and readily adapt themselves to a wide variety of soils and climatic conditions. In general one will find the American types of Arbor Vitae (Thuya Occidentalis) the hardier from Kansas City north. Both types do well in the intermediate zone, while the Chinese types (Biota Orientalis) are more satisfactory for southern planting where they have to withstand the hot summer suns and protracted drouths. All the specimens listed below are

COHMUN CHINESE ARBOR VITAE (BIOta Orientalis) - A fast growing Evergreen which has the typical pressed foliage of the Arbor Vitae family, branches upright and parallel. Inclined to be rather open but can be made compact by shearing.
Color bright green. Seedling tyce.

BAKEIR'S PIRAMHDA ARBOR VITAE (Biota orientalis Pyramidalis)-A very well-formed, compact, uniform, pyramidal tree. It grows broad at the base and tapers to a point at the top. Deep green in color. Does not require shearentrances and in formal work.

CHINESE COMPACT ARBOR VITA (Biota orientalis Compacta)-Compact (Biota Orientalis Compacta)-Compact dwarf type of the Biotas, the follage plain Chinese. Color deep green.

IBERCKMAN'S GOLDEN ARDOR VITAF (Biota orientalis Aurea Nana)-Form and foliage very similar to Biota Compacta but the tips carry a conspicuous bright golden color. Very attractive. foundation plantings where added color foundation
is desired.

MAYHEW'S GOLDEN ARBOH VITAFA beautiful light green type of compact Biota Orientalis with the golden tip but not so pronounced as on the Berckman's

ROSEDALE ARBOR VITAE (Biota Orientalis Hybrid)-The foliage is quite differint sita itae and Juniper. It is a bluish color during the winter, new growth in the spring coming out brigh

AMIERICAN GLOBE ARBOR VITAF: (Thuya occidentalis GIobona)-A wellshaped type of the native species. The shread is as of the native species. The dom gets over 3 to 4 ft. Maintains its

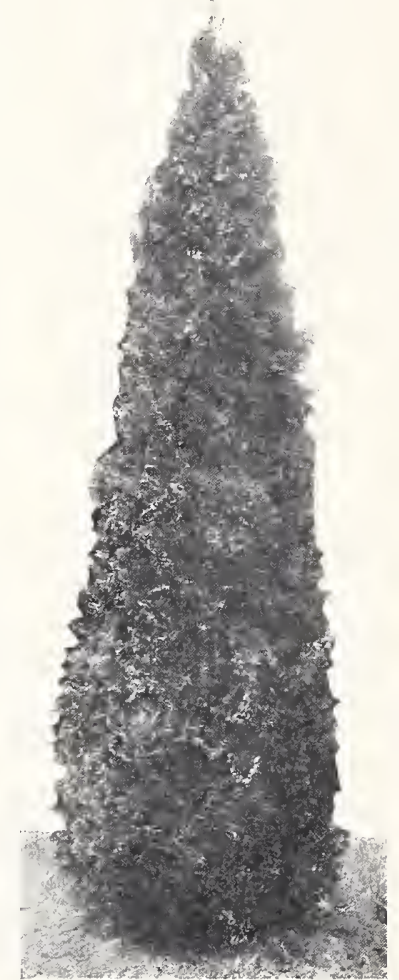

American Pyramidal Arbor Vitae suitable for groups or foundation plantings with the exception of Norway Spruce.

One should bear in mind that it is not the sudden freezing that hurts Evergreens, but rather the sudden thawing after freezing, and contrary to the conimon idea groups planted on the north side are less susceptible to injury than those planted on the south.

\section{Planting Hints}

Plant as soon as possible after receiving shipment. As soon as received, unpack, submerge the earth ball in a tub of water for 30 minutes. Do not stand in the sun, but place in a cool, shady place out of the wind. Prepare the soil well. Dig holes several inches wider and deeper than the ball. Set the trees straight and slightly deeper than they stood in the nursery row. Leave the burlap around the earth ball but cut the strings after placing in position. Tramp the dirt firmly around the trees. When the hole is nearly full, pour in a couple of pails of water. Fill the balance of the hole with loose dirt. They should be kept well watered throughout the summer, cultivating the surface for a foot or eighteen inches around the trees. Do not put stable manure in the holes when planting. Loose straw or wellrotted leaves used as a mulch on top of the ground make a good fertilizer and help protect them against winter injury.

HONI'A (Biota Orientalis)-At beautiful globe arbor vitae exceptionally attraetive and useful. Rich green color. Slow growing and therefore desirable in locations where other varieties would locations where other varieties would landscape plantings.

globe shape without pruning. Dark green. Splendid for tubbing and entrances. Stands severe temperatures, Measured by spread of specimens.

A MEIRICAN PYRAMIDAL ARHOR VITAE (Thuya occidentalis Pyramidalis) The same type of foliage as the American Globe but pyramidal in shape and grow to a height of 12 or $15 \mathrm{ft}$. Is often used for sentinels at entrances. Good for
formal effects. Keepsits ryramidal form
without pruning. Dark green. Stands without pruning. D
severe temperatures.

'PFITZER'S JUNIPER (Juniperus Chinensis Pfitzeriana)-This is a low spreading Juniper, very hardy, standing both very hot and cold temperatures. It is strikingly graceful, long plume-like branches, foliage a bright silvery green. May be trained in an upright form by by spread of specimens. 12-18 in. spread.

IRISH JUNIPER (Juniperus Hibernica) Juniper of formal habits. Grows to height of $15 \mathrm{ft}$. Foliage sage color or height of 15
bluish green.

NORWAY SPRUCE (Picea Excelsa)-A tall evergreen tree of rapid growth Most widely planted and the hardiest of the Spruces. The branches are spreading and drooping. The color is very dark green, the rafid new growth each
season being light green. Grows to season being light green. Grows to meight of $40 \mathrm{ft}$. Used mostly as a speciing.

RETINOSPORA PLUMOSA-A handsome, feathery, medium growth Evergreen with plume-like branches. Conical in
IBELIA GRANDIFLORA-A very pretty shrub of unusual value. Blooms profusely from July to Seftember. Leaves the fall; flowers tube-like, about an inch long, white on inside, delicate pink out; fragrant. Holds its foliage all out; fragrant. Holds its foliage all winter as far north as Tulsa. Deciduous Kansas City.

\section{Kind Words From Our Customers} Nurseries Co. and have never had such one else. I have found their stock to be the most reasonable in prices in accordance with the fine quality of stock received and am impressed with the way every piece has grown."-W. P. Harrell, Fla. ne several months ago are loing excep tionally well and I am very much pleased stock and wish to thank you for the prompt and courteous way you handled my order."-O. D. Bilharz, Kans.

I never saw trees that had such an abundance of fine fibrous roots as have been developed in the trees which you sent to me, and I thank you for sending me such good stock,"-S. E. Blackburn, Mo.

"Iast fall we purchased some evergreens from your good house. We found them to be excellent stock, and are well pleased with the collection sent."-G W. Trimble. Okla. glossy green turning coppery red in

"I have sent 3 orders to the Neosho prompt and courteous attention from any-

"The trees (10 Evergreens) you shipped with them. I can highly recommend your 


\section{Plant Trees For Shelter, Shade and Beauty}

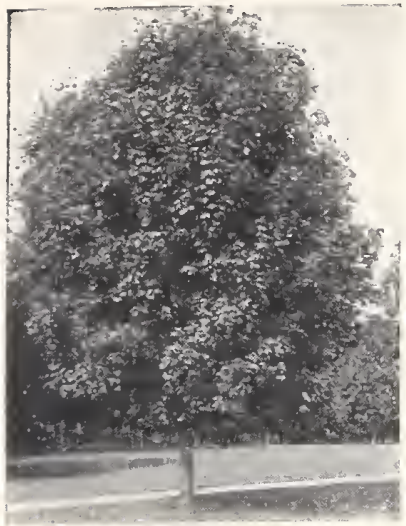

Norway Maple

Trees help to make our outdoor living rooms for leisure or play. They are needed as backgrounds and to frame the house. They add to our pleasure with beauty of form, foliage, flower and fruit, as specimens, in groups and in combination with shrubbery.

As backgrounds they are placed well back of the house line. To frame the house they are planted at both ends forward of the front line of the house. Along straight drives they are set not less than $35 \mathrm{ft}$. apart, alternately, and 5 to $10 \mathrm{ft}$. from the edge of the driveway. Along curved roads or paths they should be in groups rather than in lines.

ASH, GREEN (Fraxinus viridis) - Shapely, ro u n headed tree with slender spreading branches; rapi growing; 50 to $60 \mathrm{ft}$

ASH, WHITE (Fraxinus Americana) - Quick growing with broad. spreading limbs. Good for shade or for street planting; grows

HOX GLLER or ISH LEAVEII MAPLE (Acer Netundo -A rapid-growing spread ing tree, 30 to 60 ft. which endures dry soil. Often

CATALPA, IVESTERN (Catalpa speciosa)-Has bright green leaves and beautiful white or yellowish-white, fragrant flowers in June Rapid growing, attaining height of 60 ft. up.

ELM, AMERICAN (Ulmus Amerieana)-This is a majestic and graceful tree Valuable as specimens near house and a street trees; 80 to $100 \mathrm{ft}$.; yellow fall foliage.

ELVI, SIBEII i (Ulmus Fumila-A very fast grower, en during drought and extremes of temperature, very free from diseases and insect injury. Leaves out early in spring and sheds them late in fall. Leaves smaller, branches more slender than American Elm. Hardier than branches more slender than Ame

LINDEN. ANERICAN (Tilia Americana)-Basswood or White wood. A stately tree with large shining leaves and yellow flowers which attract honey shining leaves and to $60 \mathrm{ft}$. A good street tree.

MIPLE, HARD Or SUGAR (A. Saceharum)-Slow growing bu long-lived with beautiful foliage turning red and yellow in early autumn. Excellent for shade and lawns, also a IAPLE, NUR IVIY Acer Platanoides-Handsome, low-headed compact growing with broad, deep green foliage holding its color late into fall. Valuable for lawns and parks; 30 to $60 \mathrm{ft}$.

IAPLE, SILVER or SOFT (Acer Dasyearpum [Saceharinum]) Very fast growing, valued for producing quick shade. Over $60 \mathrm{ft}$

OAK, PIN (Quercus Palustris)-Very desirable for lawn, stree and park planting. Grows rapidly, 30 to $60 \mathrm{ft}$. Branches are drooping in form with age. Folia

POPIAR, CARoLINA (Populus Eugenei)-Very rapid growing, healthy, hardy tree with large, glossy, pale to deep green leaves; pyramidal in form; grows 25 to $40 \mathrm{ft}$. Useful for

POPLAR, LoMBARDY (Populus Nigra Italica)-A narrow, steeple-like tree, strikingly picturesque, attaining a height of 60 ft. or more; valuable as specimens, as screens, in mixed flantings for contrast
buildings. Rapid growing.
SYCAMORE (Platnus occidentalis)-Called also Buttonball or Button wood.

TULIP (Liriodendron Tulipifera)-Sometimes called Whitewood or Yellow Poplar. A large, magnificent tree, $60 \mathrm{ft}$. up. Glossy green foliage turns yellow in fall; tulip-like, greenish-yellow flowers with orange center appear in June.

WEEPING WILLOW, IVISCONSIN (Salix HIanda)-A hardy tree, 25 to $40 \mathrm{ft}$., with slender, drooping branches.

\section{Valuable Nut Trees}

BLACK WALNUT-Thrives in nearly every state. The nut of the following budded or grafted varieties are of exoH cellent quality and the kernels usually crack out in halves: THonAs-Grows larger than ordinary Black Walnut. Nut is ENGLISH II INUT-The Franquette is doing well in the Eastern, Middle and Southern states, in Oregon and Washington. It makes a large ornamental tree and bears a medium to large fine flavored nut with fairly thin shell and excellent cracking quality. One tree, 12 years old. at PECAN-Grows wild from southern Indiana and clinton Iow to the Gulf coast on a wide range of soils. Northern valieties such as Butterick and Indiana are adapted for maker,

\section{Small Ornamental Trees}

ASH, HOUN'TAN, EUROPEAN (Sorbus I ucuparia)-Hardy tree 20 to $40 \mathrm{ft}$ tall, not particular as to soil, well suited to in fall White flowers in follage turning to orange-red which hang on all winter.

BECHTEL DOUBLE FLOWERING CRAB (MaJUs IOENST:Grows 8 to $15 \mathrm{ft}$. Large, double, pink flowers resembling loses. and very fragrant, in late May. Easily started-do

DOGWOOD FLOWERING (Cornus Florida)-A large shrub or small tree, up to $20 \mathrm{ft}$. Valuable for white flowers in May; dark green foliage, bright red berries and brilliant autumn color. Grows in sun or shade.

MULBERr (Morus Alba Pendula)-Teas' Weeping; hardy, beautiful weeping trees. Grafted on a straight trunk, the branches droop to the ground.

PLUU, PURPLE-LEAVED (Prunus Pissarli)-Valuable for purple foliage. Grows 10 to $12 \mathrm{ft}$. See page 36 .

PLUM, DoUbLE-FLowering (Prunus Triloba)-Valuable for double pink bloom. Grows 6 to $8 \mathrm{ft}$. See page 36 .

RED BUD (Cereis Canadensia) -10 to $15 \mathrm{ft}$. tall, with irregular head, with mass of small fink flowers before the leaves appear. Leaves are large, nearly round, dark green. Endures shade. Used as specimens or in border plantings.

UMBRELLA CATALPA (Catalpa Rignonioides Nana)-Roundheaded tree used for specimens and formal effects. Can be kept compact and symmetrical by late winter pruning.

View of Gur Front Lawn and office

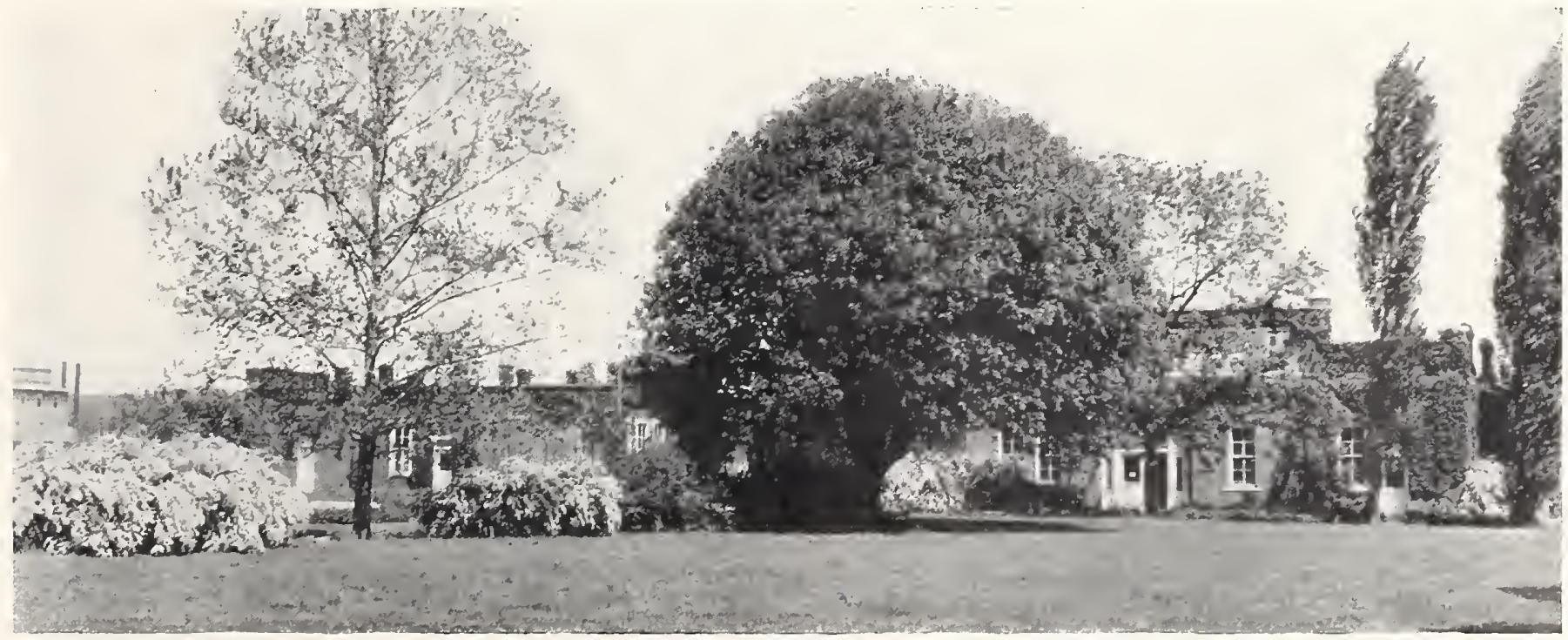




\section{Every Garden Should Have These Good Things}

\section{Luscious Strawberries}

Strawberries are the first fruit to ripen in the spring. Fresh or preserved, they are delicious and healthful, and help out on the grocery bill. Like blackberries and raspberries, they reach their highest quality when fully ripened before picking, which is not the case when grown for market. They do well on almost any soil if well drained, deeply worked and well fertilized. Standard varieties produce good crops the next spring after planting.

All the following varieties are self-fertile and can be planted alone.

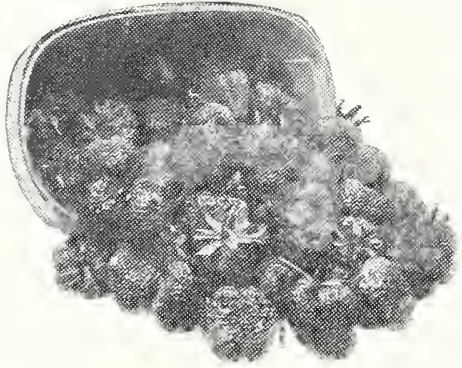

The Everbearing will produce the first summer and fall. The second year they bear in the spring and continue fruiting until severe frost comes. They are particularly fine for the home garden. Fifty to one hundred plants set about a foot apart in beds 4 to 5 feet wide will supply a small family with berries throughthe season.

Standard Varieties

A ROMA (Midseason to Late)-A richly colored, large berry. deliciously aromatic in flavor. Ripens over a long season. Its chief merits are resistance to disease, froductiveness and attractiveness, firmness and high quality of the fruit. Best adapted to silt or clay soils. 125,000 crates, 24 quarts each, were shipped out of Neosho in 1922 , practically all Aroma. They were sent to New England, Canada, ColoAroma.

(Senator) DUNLAP (Midseason)-One of the most widely clanted varieties. Noted for dependability and productiveness. A medium sized handsome berry, deep glossy red, exceedingly juicy, very good quality. Plants are very hardy and drouth-resistant. Adapted to any type of soil and wide variation in climate.

OzARK (Early) (Extra Early)-Dark red, excellent quality berry, large for their season. The plant is vigorous and berry, lar:

\section{Everbearing Strawberries}

CHAMPION-This is a very heavy fruiter of medium-large choice berries. Begins bearing about three months after plants are set. and as the season advances the berries increase in number and size; berries dark red, sweet, fine flavor, evenly colored; firm and will stand rough handling.

HASTODON-Now holds first place among the everbearers. Produces great quantities of the largest berries of any heavy fruiter. Successful both for home gardens and as a commercial variety.

PIROGIRESIVE (Everbearing)-Bear first summer and fall, second year in spring and fall. The berries are medium size, dark crimson, and delicious in quality. The plant is unusually healthy, vigorous, very hardy and productive. It needs a rich soil amply supplied with moisture. If an early frost catches one set of blossoms, another is formed immediately. The first season the blossoms and runners
should be cut off until about the middle of July.

\section{Cultural Directions for Strawberries}

Cover the ground with well-rotted manure-a wheelbarrow load to each 100 square feet. Plow or dig the ground and pulverize deeply and thoroughly.

Do not plant in ground that has just been in sod; if you do, the white grubs will probably destroy the plants.

Cut back the roots to about 4 inches and put them in water.

Be particularly careful to set plants the correct depth the crowns just level with the surface, and firm the soil about the roots.

Cultivate about once a week, and only an inch or two deep, but not when the ground is we

keep the blossoms ficked off the first season on standard varieties and until about July 1st on Everbearers.

The hill system produces the largest and finest berries. The plants are set 18 to 24 inches apart each way, which allows cultivation both ways, or 15 to 18 inches between plants in rows 24 to 30 inches apart. In either case all runners must

\section{Horseradish}

The best quality and largest size is produced in a deep loam, moderately rich, well supplied with humus; good drainage and a fairly open subsoil are essential.

Plant about 18 inches apart in rows 3 feet apart and cover 2 or 3 inches deep. Cultivate during summer as often as needed to keep down weeds and conserve moisture.

\section{Early Asparagus}

Every home garden should have asparagus, one of the earliest and most wholesome vegetables, and when canned retains its flavor better than most vegetables.

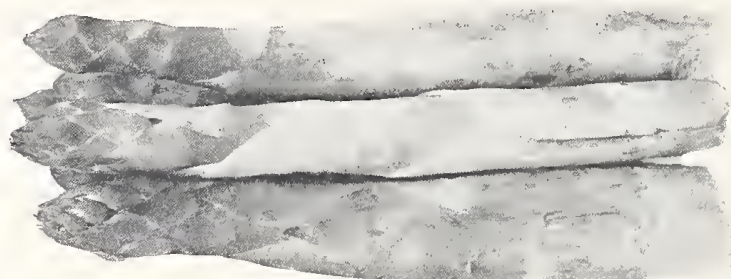

WASHINGTON-The most resistant to rust and is also superior in color, size and flavor.

soil.

Plow deep and mix in thoroughly 2 or 3 inches of well-rotted mature. Set plants 15 inches apart in rows 3 feet apart. Cover the crown or top about 2 inches.

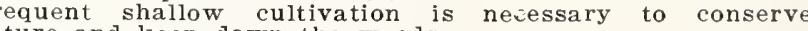
Early in fall. cut the stalls clods.

close to the ground and remove from the patch. Cover with coarse manure 3 inches deep. barly in spring remove all bo

Cut few, if any, shoots untll third season.

Apply a pound of salt to about 128 square feet.

\section{Delicious Rhubarb}

Is hardy in all parts of the temperate zone. Comes at an early season when most needed and appreciated.

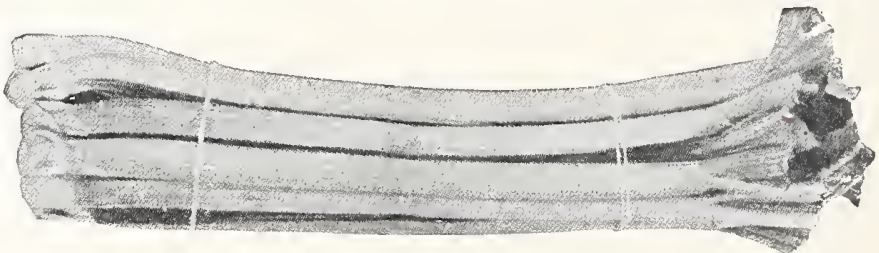

Plant in fall or spring, 3 feet apart in rows 4 feet apart

The crowns should be barely covered with dirt. If planted deep they are almost sure to rot during the hot weather of the first season.

Thorough cultivation should be given through the summer and liberal afplications of manure every winter.

In gathering the leaf stalks, the base of the stalk should be pulled out, for if broken off at the surface of the ground the rotting of the short piece left causes "stem rot."

The Right and wrong way to set Strawberry Plants.

A-Too Shallow H-Too Deep C-Just Right

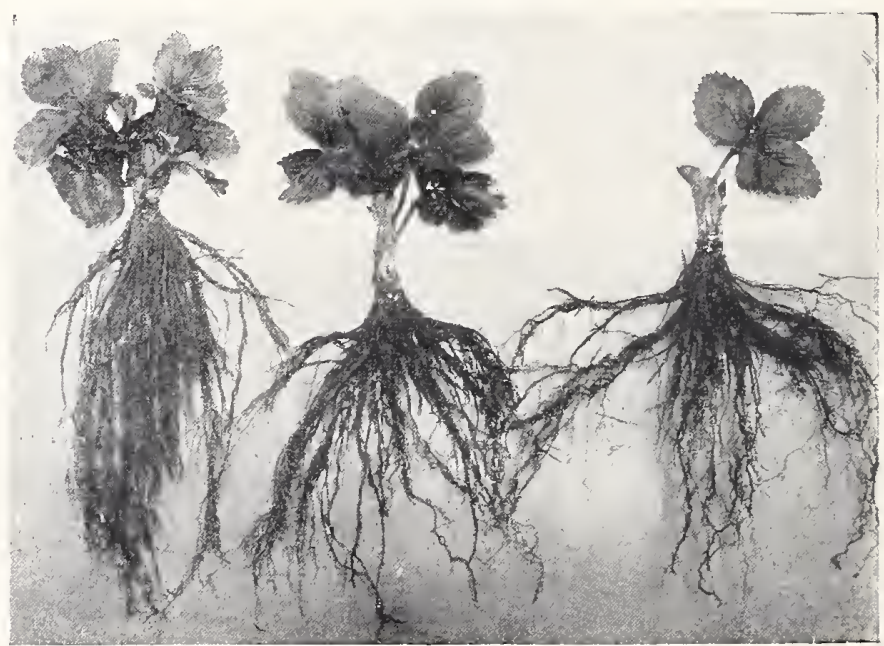




\section{Home Grown Berrie
Blackberries and
Dewberries}

City people do not know the really delectable flavor of fully ripe blackberries, since, even for local markets, they must be picked before they are fully ripe and they do not ripen in transit. The cultivated varieties are much juicier and larger and better in quality. They are easily grown and bear abundantly the second year.

EARLY HARVEST (Early)—Glossy black, medium size, good quality not very hardy, requiring protection in the North.

ELDORADo (Midseason)-Medium to large, jet black, sweet and melting, very good quality; very hardy; vigorous and productive.

MeDONALD (Very Early)-A blackberry-dewberry hybrid. It is large, oblong, very good quality; drouth-resistant, vigorous grower; plant in rows eight to ten feet apart. The vine trails on the ground the first season like the dewberry but
grows upright the next year. Grown in Missouri, Oklahoma grows upright the next year. Grown in Missouri, Oklahoma
and Texas. Not hardy and is self-sterile. Plant every fourth row with Lucretia Dewberry or Early Harvest to develop good berries.

LUCRETA (Very Early) - The best known and most widely planted dewberry. The berries are large, long, firm and
good quality, very sweet if left on the vines a dav or two after they would be picked for shipping.

\section{Cultural Directions for Blackberries}

Where winters are mild flant in the fall but mulch with straw or coarse manure for winter protection.

Plant 3 feet or more apart in rows 5 feet or more apart Set an inch or two deeper than in the nursery row and cut Cultivations to 6 inches or less.

Cultivation should begin as soon as the plants are set and continued every week or two until a month before freezing weather. Pinch off the tops of the young canes when at a height of $21 / 2$ feet- 3 feet. Immediately after Ficking, old new canes to each plant.

new canes to each plant. in the row and the canes tied to a wire about $2 \frac{11}{2}$ feet above the ground.

\section{Gooseberries and Currants}

Are used chiefly in making jams, jellies, preserves, pies, tarts, etc. They contain a large amount of pectin, which is necessary for jelly making. Gooseberries are grown slightly farther south than Currants, suffering less from hot, dry weather. Bear second or third year.

\section{Currants}

LONDON MARKE'T CMidseason to Late)-Very hardy. Medium to large, dark red, pact.

perfection (Midseason)Large, bright red berry in Large, bright red berry in sprightly, subacid. Vigorsprightly, subacid.

ous and productive.

WHite GRAPE-The best white currant. Large clusters of white or goldengreen berries, mildly acid in
flavor: slender but productiavor; slender

Cultural Directions

Plant in fall except where

winters are severe. among fruit trees the foliage is usually healthier and the plants more productive in such locations.

Set 4 feet apart in rows 6 feet a part.

Broken roots should be cut off and the tops cut back to within about 6 inches of the ground. Set a little deeper than they stuod in the nursery.

\section{Gooseberries}

Dowvivg-The most widely grown variety; medium to grown variety; medium to and very productive: rarely and very productive orefor (Chimpion) - A Rarge green berry, season large green berry, season late. Very productive, rarely attacked by mildew. An improved variety which combines the large size and ing with the productiveness ing with the productiveness Cultural Directions The soil should be cool, well drained and very fertile. Silt or clay loams are best. Cultivate frequently during the growing season. After the first year the cultivation should be shallow.

Liberal quantities of stable manure and wood ashes wil generally prove profitable.

The currant worm attacks both gooseberry and currant and should be sprayed as soon as they appear with arsenate waste to 50 gallons of water.

"My Yard Gets Much Attention""

"A few years ago I started phanting some of your trees and shrubs and throush your wondertul catalog of information and a little study I have a most pretty yard and home of my own phatuting and arranging and which eatuses no litere attention from friends and others who very often ank where I get my shruls."-F". C. Deputy, Ho.

\section{Are Truly Delectable}

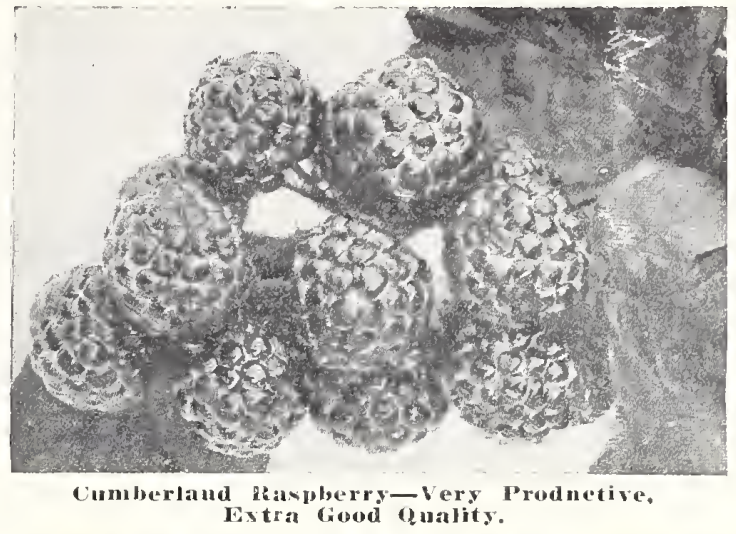

\section{Tempting Raspberries}

This tempting fruit is easy to grow and is produced the second season after planting.

CARDINAL (Purple)-Most popular purfle variety in Missouri. Hardy and drought resistant.

CUMBERLAND (Blaek) (Midseason) - The most widely planted black raspberry because of its productiveness and quality. Berries are extra large, fine and sweet.

CU'THBEIRT (Red) (Late)-The best red because of its superior quality and flavor. Berries are large, rich crimson firm and one of the best for canning.

KANSAS (Black) (Early to Midseason)-Large, firm, sweet well-flavored berries and strong, prolific canes, resistant to drought.

IRANERE (St. Regis) (Red) (Everbenring)-Bright red, small to large berries. Canes are hardy, prolific, healthy, drouthresistant. Bears very early; after old canes have borne the young canes begin bearing and produce until frost. Very thorough cultivation is necessary, otherwise berries succeeds further south than other varleties.

\section{Cultural Directions for Raspberries}

May be planted in the fall where winters are mild, but should be mulched with straw or coarse manure for winter protection. Usually spring is the best time, esfecially with black or purple varieties.

Space plants 2 to 4 teet apart, in rows 5 to 8 feet arart, red varieties closer than blacks. Set an inch or two deeper than they stood in the nursery, in good rich soil; ground bone is a good fertilizer. Keep well cultivated and free from weeds and suckers. Pinch back the young canes of black raspberries when 18 to 24 inches tall. This causes side branches to grow on the canes and makes the bushes more stocky and self-supporting. The next spring cut the side branches back a third to a half.

Red raspberries require no pruning excert where the canes are very tall they may be cut back to 5 or 6 feet in height. Leave not more than 4 or 5 canes per plant, except possibly with very vigorous growers. Remove and burn old canes when the crop has been picked.

The dewberry trails on the ground and the tops are usually tied to stakes or wires in the spring. In cold climate a muleh of straw or earth is necessary in the winter. liamere (St, Regis) Raspherry-Bears two
crops, sprins and fall. 


\section{Neosho Ozark-Mountain Grown Buy Fruit Trees by Diameter or Thickness}

Neosho Trees Graded by Diameter This is a bundle of 10 two-year Apple trees $11 / 16$ in. up in diameter, 5 to $7 \mathrm{ft}$. tall. Note how uniform the trunks are, graded by the diameter about two inches above the ground. They are headed 28 to 30 inches high and have plenty of tops to cut off and throw away after you plant them. They are well-rooted, clean, healthy and in prime condition. Ten of them weigh about 20 pounds and have to go by freight or express. There are none better at any price.

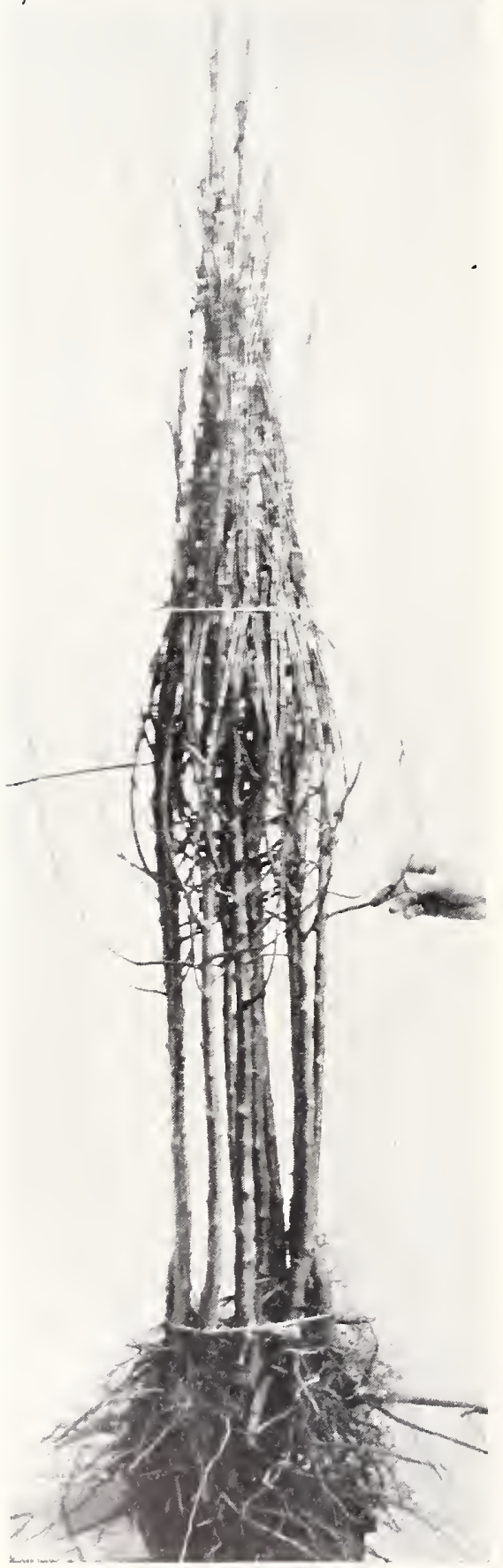

W ${ }^{\mathrm{E}}$ grade our fruit trees by diameter, measuring the thickness of the trunks two inches above the ground. This insures better values to our customer's. The reason is this: At planting time you have to cut off $1 / 3$ to $1 / 2$ the tops in order to restore the balance between tops and roots, because some of the roots are bound to be lost when the trees are dug in the nursery. Surely you are not concerned about the part you throw away, but rather about the part you have left.

Suppose you prefer the largest size two-year apple (2 yr. root). We would send you trees whose trunks are $11 / 16$ of an inch thick and from 5 to $7 \mathrm{ft}$. tall. But if we graded by height only we could send you trees as small as $7 / 16$ of an inch thick, but just as tall as the 11/16 in. You can see what a difference there would be by looking at the following illustration of sizes according to diameter:

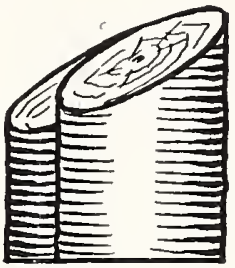

$11 / 16$ UP

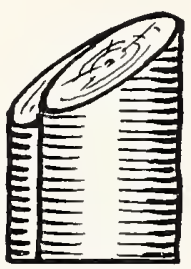

$9 / 16^{T 0} 11 / 16$

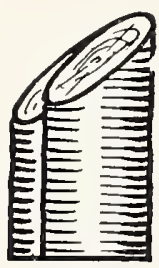

$7 / 16^{\text {TO } 9 / 16}$
When nurserymen buy fruit trees from other nurserymen, they are graded by diameter. The buyer can tell in advance what he will receive only when he buys by diameter.

We took 100 of each size Jonathan apple trees (two-year top, two-year root) at random from our stock and regraded them by height. Out of the 300 trees, 247 were 5 to $7 \mathrm{ft}$. tall, 50 were $4 \mathrm{ft}$. up, and 3 were $3 \frac{1}{2} \mathrm{ft}$. up. These 300 trees graded by height would cost you at the 100 -rate, $\$ 114.23$, but the same trees graded by diameter according to our method would have cost you only \$89-a saving of $\$ 25.23$. (Ask for quotation of 250 trees or more.)

Our trees are noted for their root systems and vitality. They are clean and healthy, free from injurious insects and disease, such as aphis, nematodes and crown gall. There are no better trees obtainable at any price.

\section{Experienced Orchardists Endorse Neosho Trees}

"I regret my failure to get in touch witl you at least three years ago, feeling as I do that it wonld have saved me many dollar

"Stock was received in fine condition and was certainly very satisfactory. The plants were much larger than I expected."-Morris Seiple, Mich.

"We have planted nearly a hundred acre with your trees and have been well pleased with them as they have done re

"Of all the nursery stock we received this spring, we received stock from five concerns, yours canne packed the best and gre "I wish to express my trees I bought of you one rear ago. They have made a fine growth. I like your way of doing business."-J. E. Aliderson, Iowa.

"The young trees (380) are growing fine."-R. L. spaulding. III.

"I was very much pleased with the trees (126), es pecially the apple trees. They were as fine a lot as ever saw," John G. 3 recken ridge, ohio.

"Whe trees we got from you this spring are doing wonderfully well and so far have only lost eight tree out of the thirteen humdred and seventy-five."Riverside Fruit Farm, Kans

"I wish to say that we were very much pleased think that they were very much above the ordinary. - Lestie S. Smith, Nebr.

Whis is a sectional view of Oakmont Orchard, owned lo 18. S. Hommel, Knoxville. Tenn. Since 1917 he has sent us 29 orders, over \$1,200 worth.

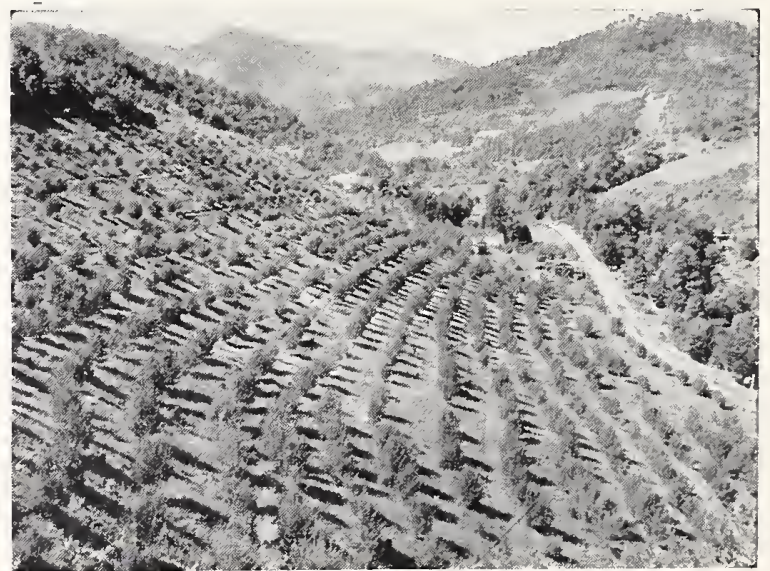




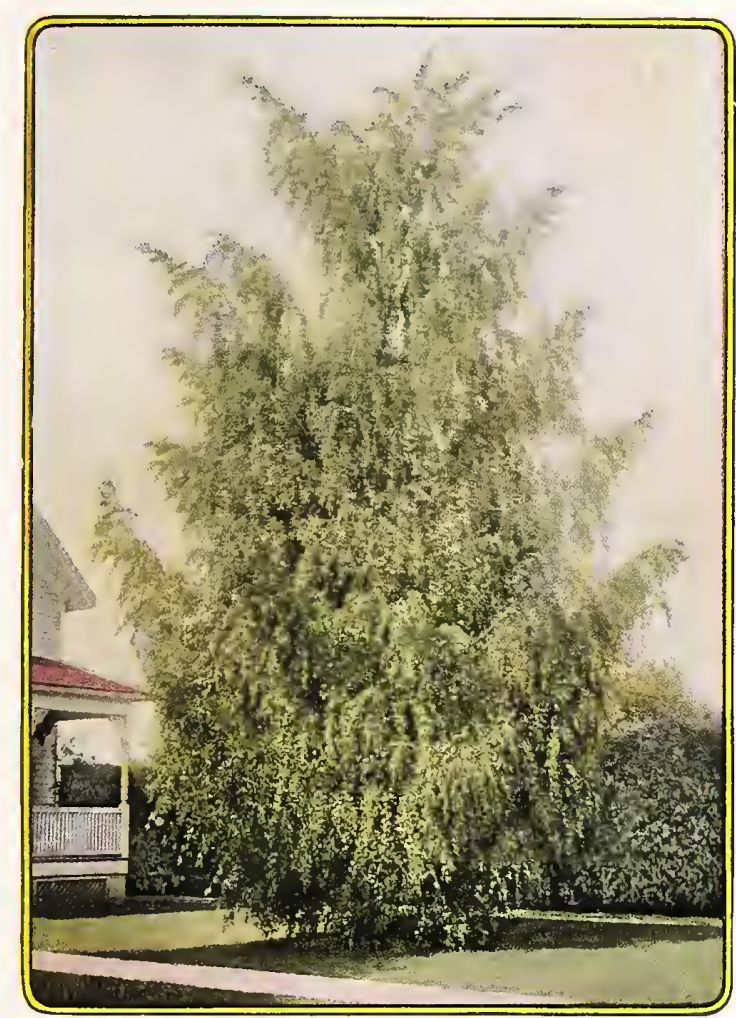

WEEPING BIRCH (Cut-Leaved)

A Beautiful Specimen Tree

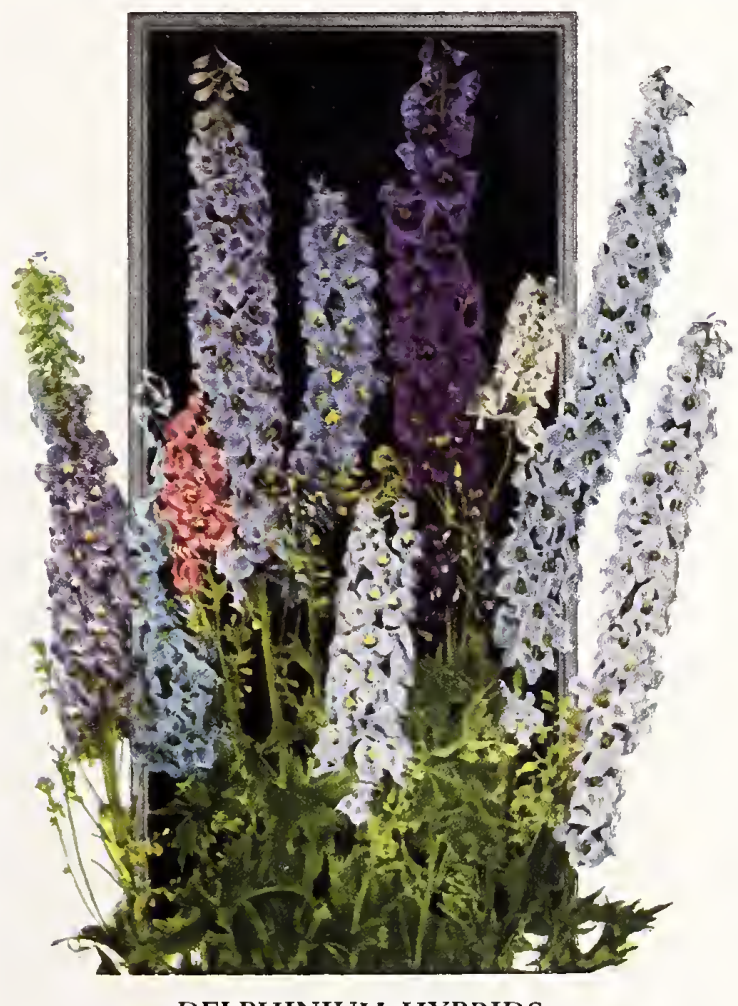

DELPHINIUM HYBRIDS

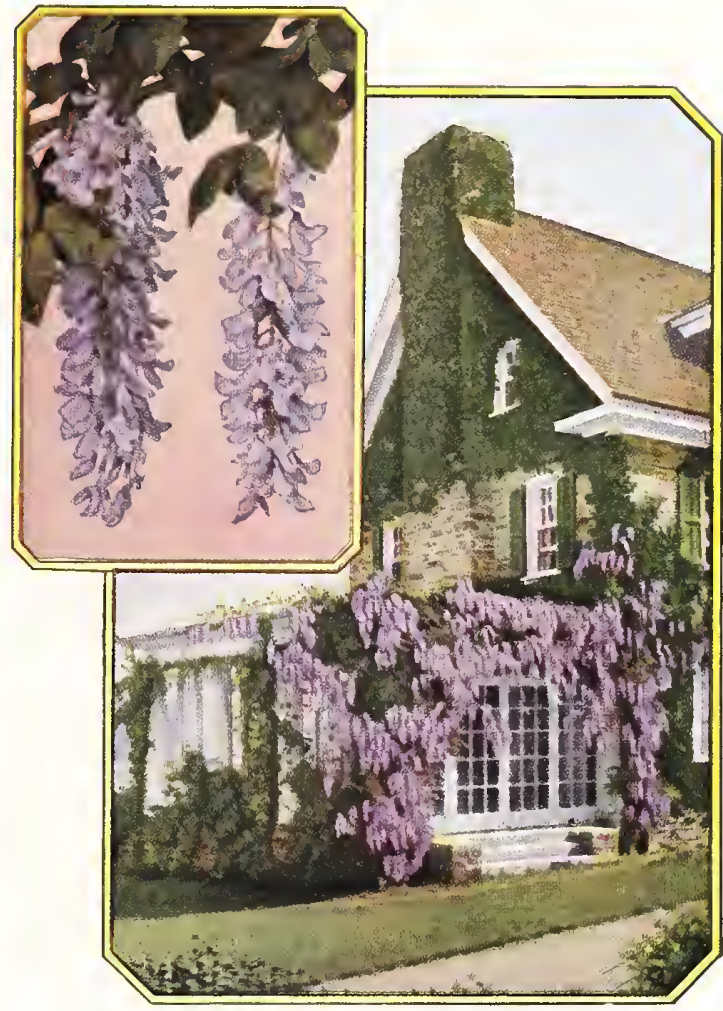

WISTERIA

Grafted Plants Insure Blooming

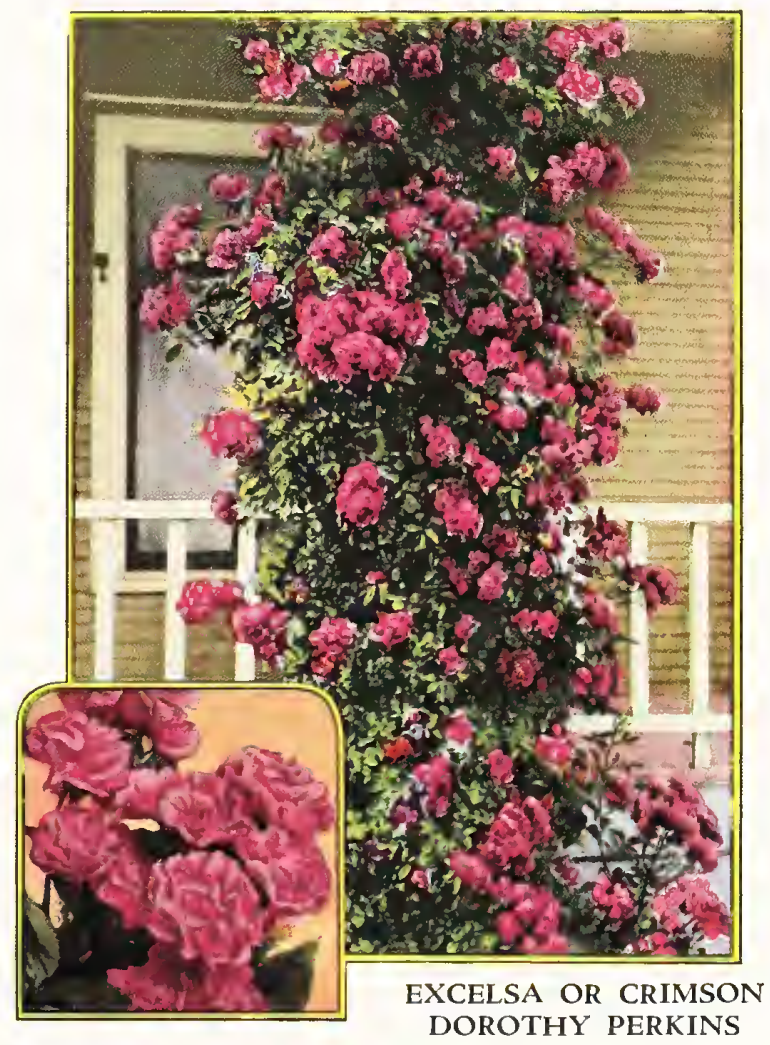

Good plants, plus good care, bring rich rewards. Our customers say w'e chose the right slogan, "Yours for Growing Satisfaction."

NEOSHO NURSERIES CO., Neosho, Missouri 

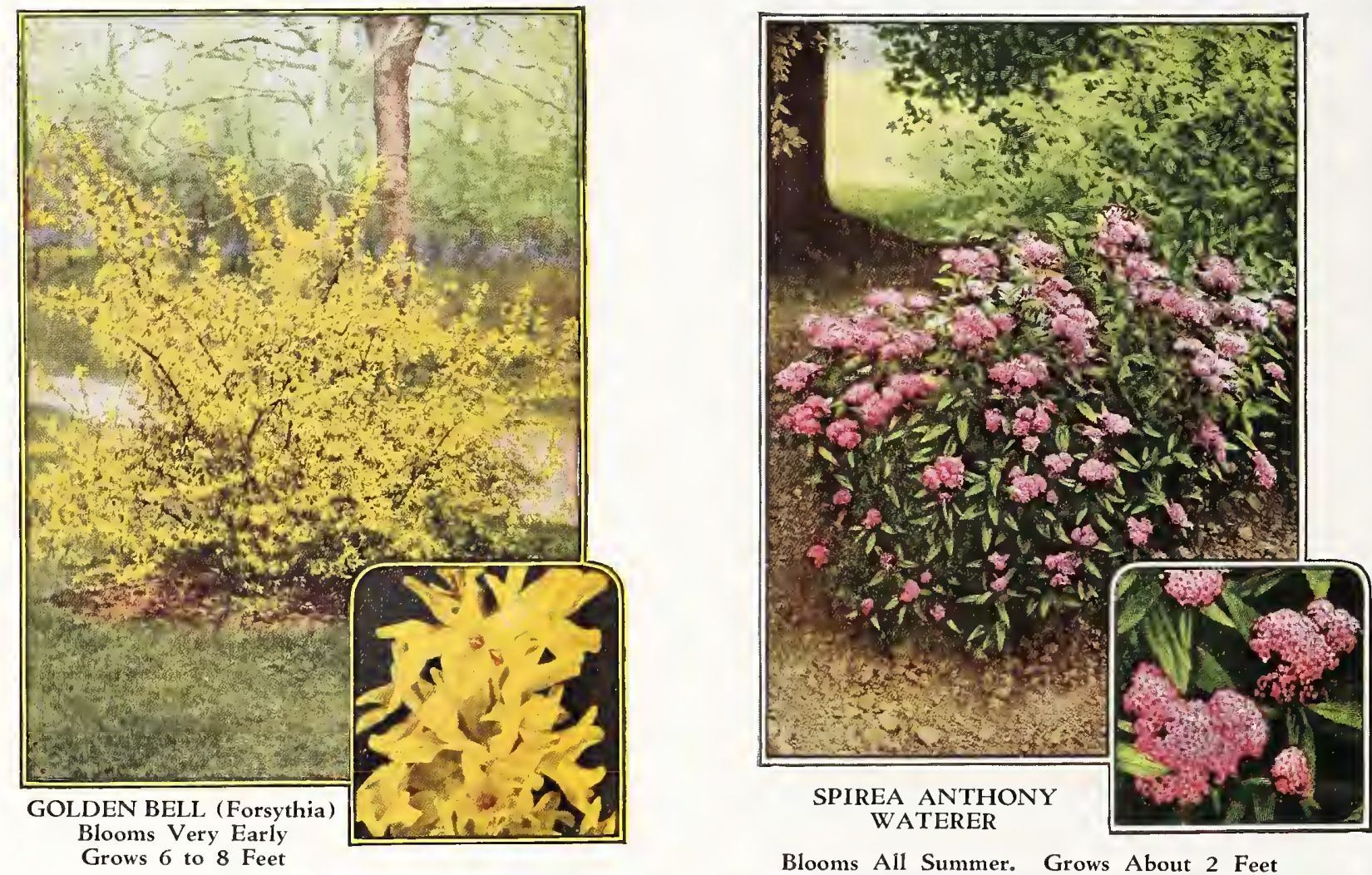

Blooms Very Early
Grows 6 to 8 Feet

Blooms Ail Summer. Grows About 2 Feet

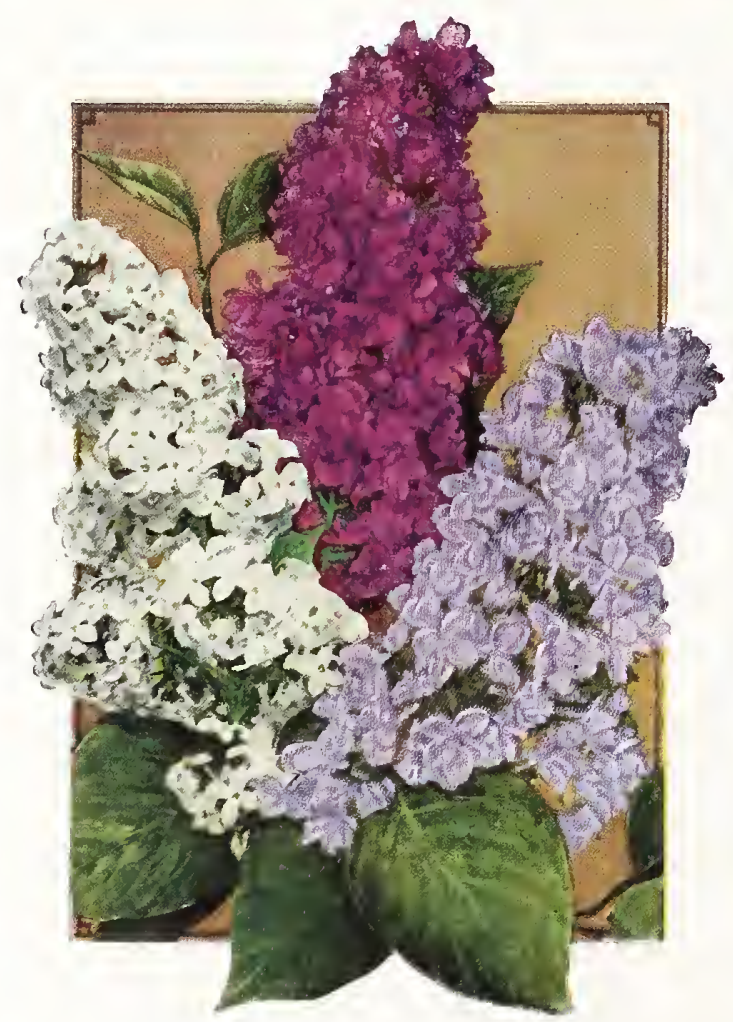

BUDDED LILACS (French Hybrids) Have Larger Blooms in Various Colors

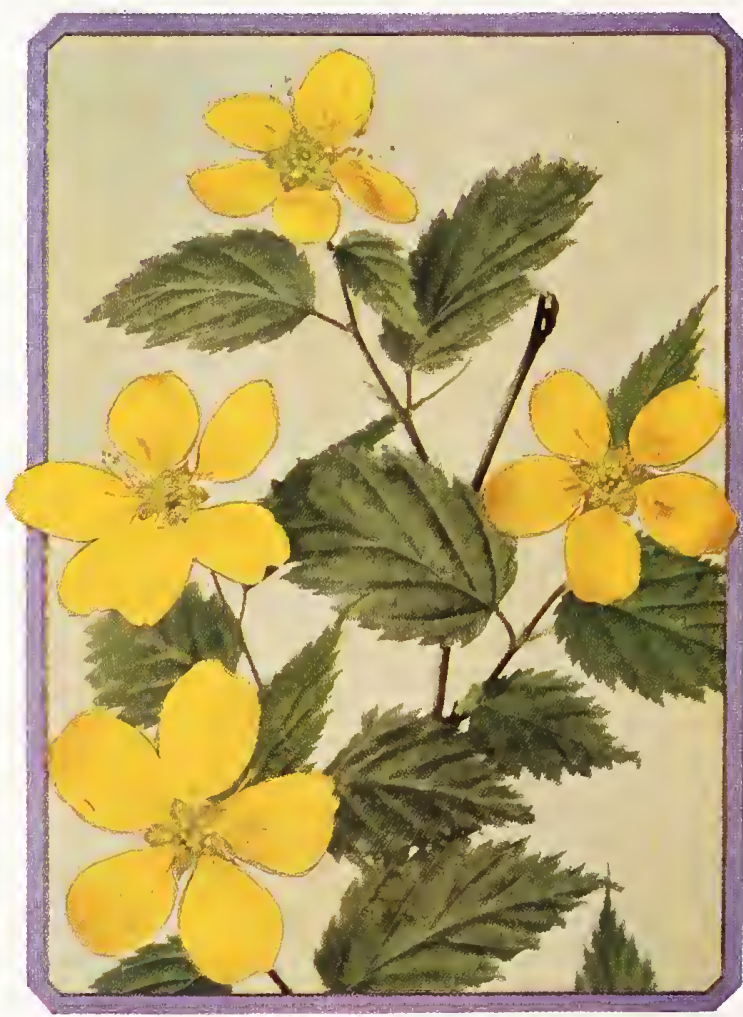

KERRIA-Japonica (Japan Corchorus) Globe Flower or Japanese Rose

Shrubs lend beauty and finish to the home. They are invaluable-as specimens; in groups or continuous borders; as screens against objectionable views or to secure privacy; as barriers or windbreaks; for flowering effects; for attractiveness of foliage or fruit.

NEOSHO NURSERIES CO., Neosho, Missouri 


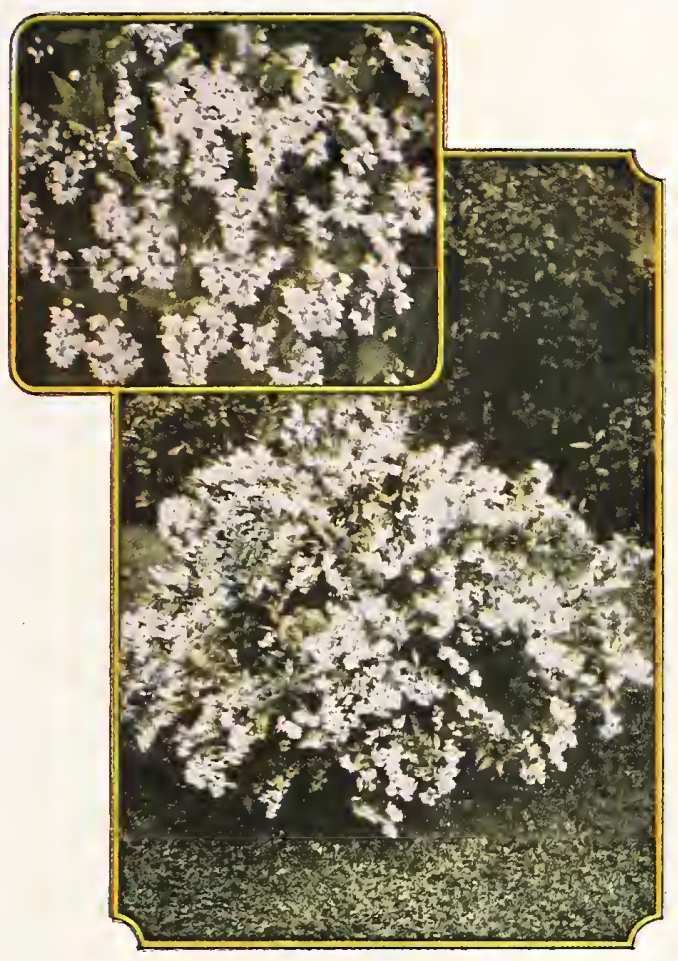

DEUTZIA GRACILIS

Blooms Early May. Grows 2-3 Feet

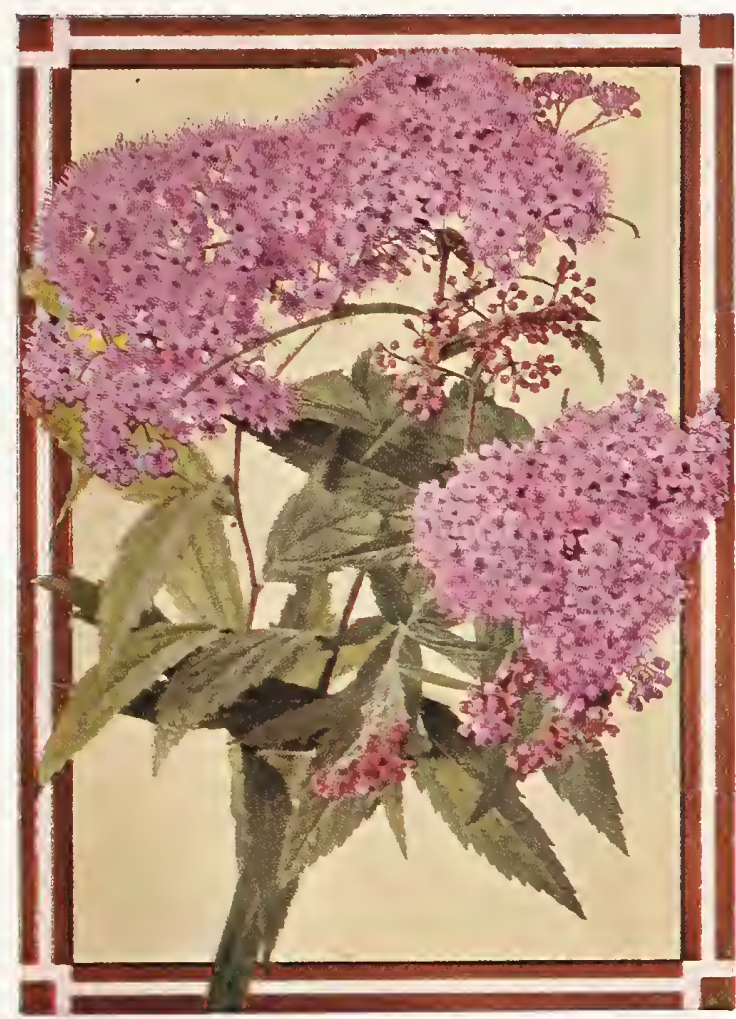

SPIREA FROEBELI

Blooms All Summer. Grows 2-3 Feet

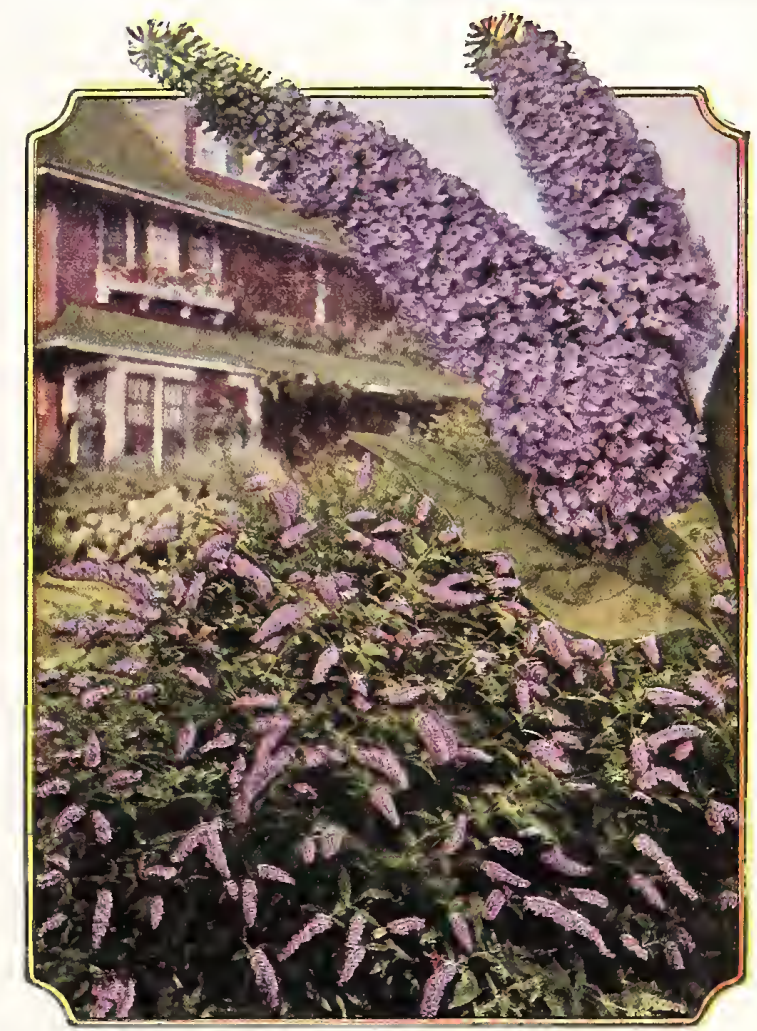

BUDDLEIA-Butterfly Bush (Summer Lilac) Blooms July - August

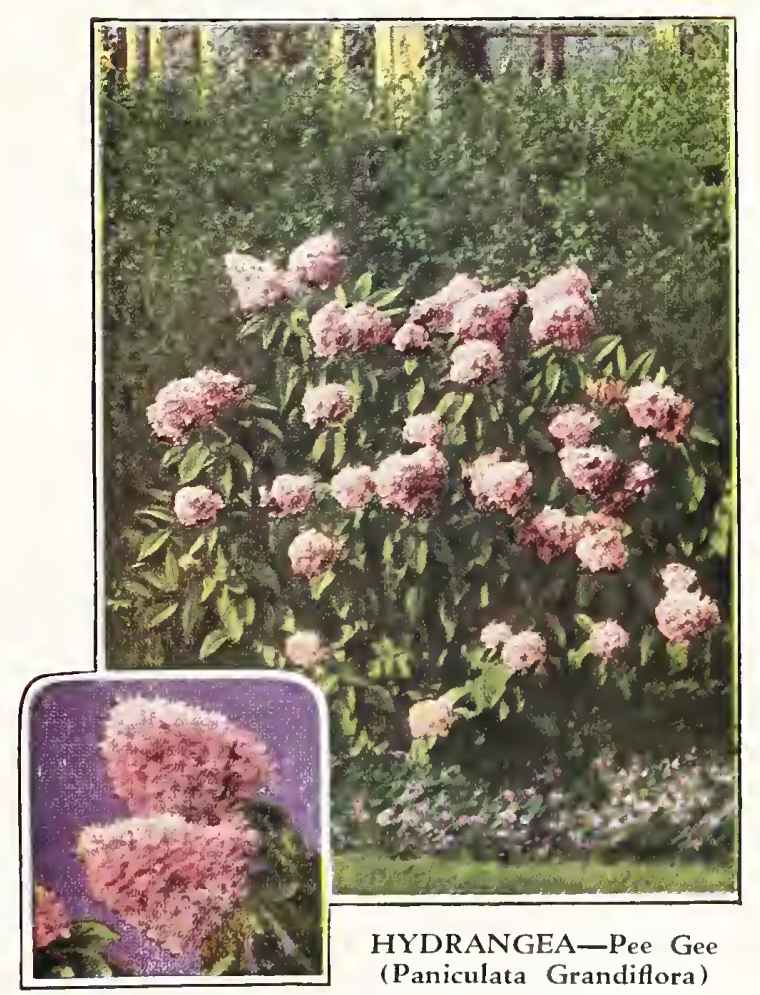

Blooms July to September. Grows 6-8 Feet

Shrubs are the foundation of all landscape plantings. Increase the beauty, comfort, and value of your property by using our landscape service as explained on pages 5 and 6 .

NEOSHO NURSERIES CO., Neosho, Missouri 


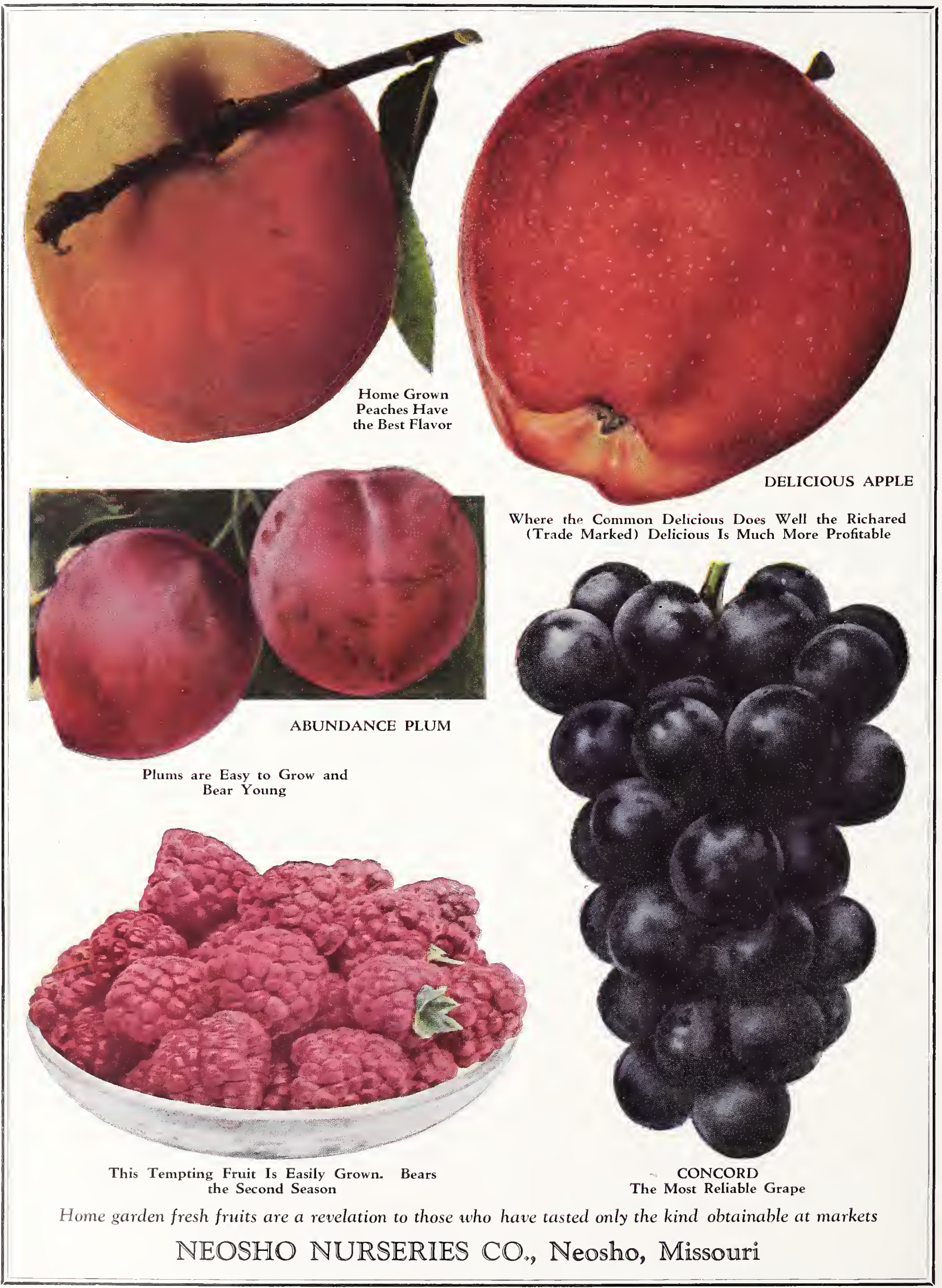




\section{FACTS ABOUT FRUIT TREES}

WHEN you plant an apple orchard remember $W$ that the purchase price of the trees will be small compared with the cost of bringing the orchard into profitable bearing. Any trees that do not come into successful bearing will have cost not only the purchase price but also the time, labor and money expended in its care.

If you plant trees that have made a good free growth for their age and variety; with good root systems, clean and healthy; and in good condition, you don't need to worry about whether they are "Whole-rooted" or "Pedigreed" or "Acclimated." Here is the truth about these matters which has been proved many, many times by disinterested experiments.

This is a quotation from circular 206, August, 1928, of the Missouri College of Agriculture.

\section{Whole Root and Piece Root Trees}

"Data show that there is no material difference between the average growth and yield of Jonathan apple trees propagated from whole roots and piece roots. It rather emphasizes the fact that the grower should give attention to the matter of securing healthy, vigorous, growthy trees with good root development than to the question of whether the trees were propagated from whole roots or piece roots. No appreciable difference was observed in the character or quality of the fruit from the whole-root and piece-root trees."

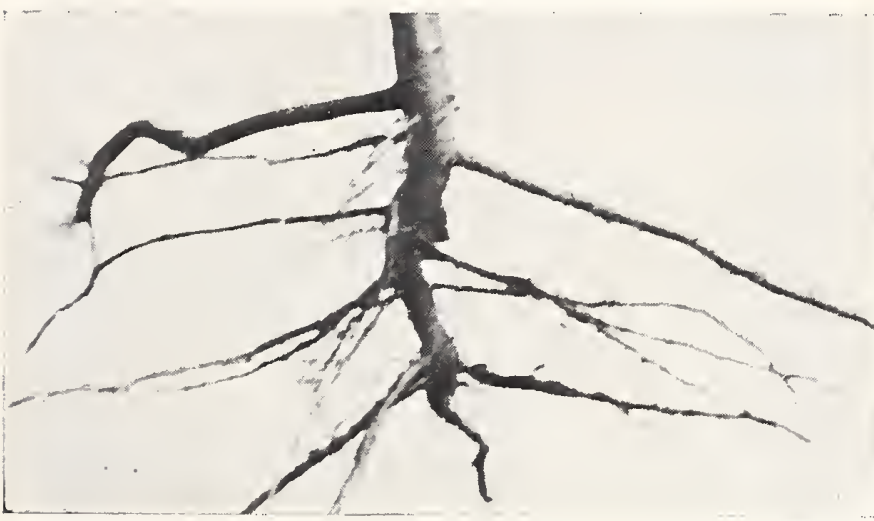

Here are pictures of roots of two of our trees. One was grown from a piece root. The other was budded and therefore grown from a whole root. Can you tell which is the whole root?

We propagate by budding all cherry, peach and plum, most varieties of pear and some apple. These are of course wholerooted. We propagate some pear and apple by grafting. Our two year apple are grafted. Our one year are some budded and some grafted, the latter produced in one season. There are no secret processes of growing nursery stock.

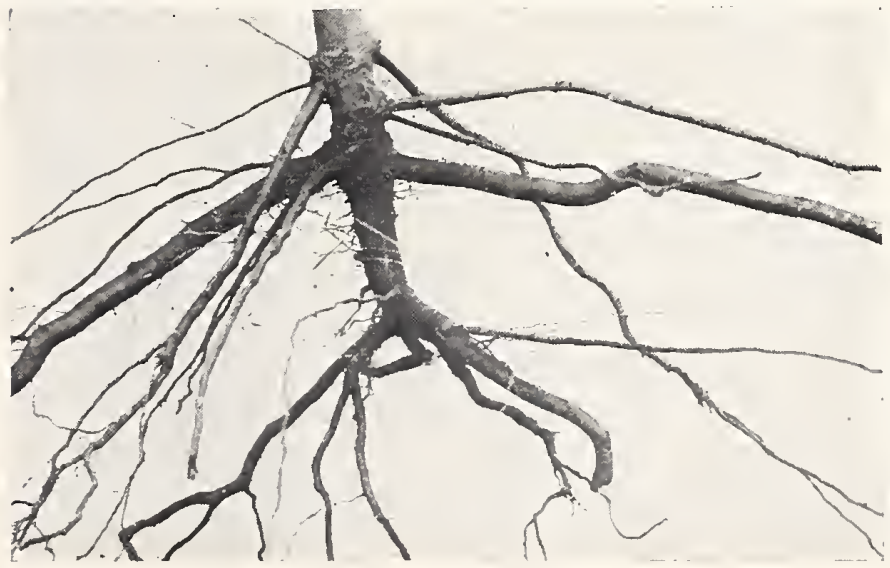

\section{HAVE AN APPLE!}

Every home garden and farm should have at least a few apple trees of summer, fall and winter varieties. They will give satisfaction far beyond the time, labor and money required.

This condensed table will help to choose an assortment that will give you afples the year round if you have a good cellar. Most summer and fall varieties ripen over a period of severa weeks and many are good for cooking before ripe. Winter varieties are picked when mature but before they are ripe enough to eat. Maturity can be told by the changing from a hard dead green color to warmer reds and yellows, by the seeds turning brown and by the readiness with which the stem separates from the twig. Varieties marked are adapted only to northern climate.
Under "Size." M-Medium; M-L-Medium to Large; I-Large; Under"Quality," F-Fair; G-Good; V-G-Very Good; B-Best Under "Use," Ć means for Cooking; D for Dessert.

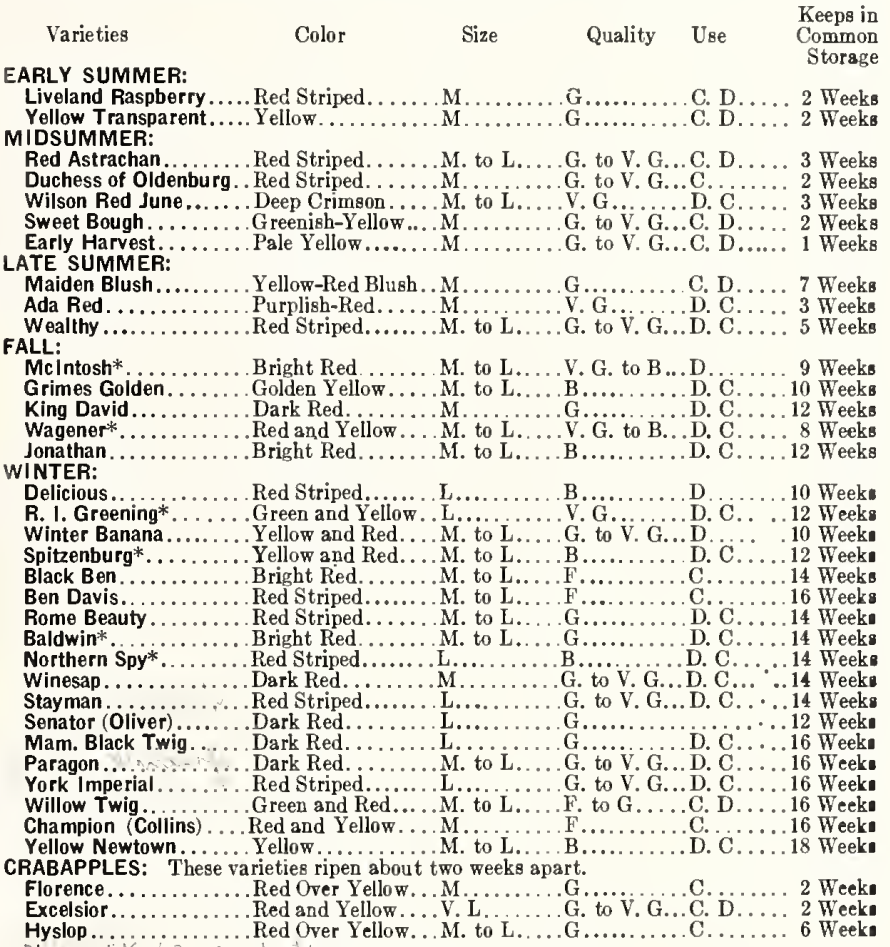

\section{Acclimated Trees}

"The section of the country from which trees are obtained is unimportant so long as the trees are well-grown, healthy and typical of the desired varieties. The growing of good trees depends upon favorable conditions and proper management in the nursery."-H. P. Gould, U. S. Pomologist, in Farmer's Bulletin 917

Our stock is giving satisfaction in every state, in Mexico, England and other foreign countries.

\section{Pedigreed Trees}

A "Pedigreed" tree is supposed to be one that was propagated from a tree which bears more heavily than others of the same variety. Read the results of experiments printed in the Encyclopedia of Practical Horticulture. The conclusion is, "No fruit grower or nurseryman is warranted in assuming that the qualities named, size of fruit, vigor, hardiness or productiveness, can be handed down."

Experiments over 12 years at the University of Missouri were made with Ben Davis apples with this result: "We have as good yielders taken from the poor vielding parent as with the others," and "As poor yielders taken from the good yielders as from the others."

\section{Better Trees at Reasonable Prices}

A Government Crown-gall investigator inspected 2,250 of our apple trees just as they came from the nursery row in the fall of 1927 and reported not one tree with crown-gall. That is truly amazing as another investigator said and he took a keg of our soil for experimental purposes. The experts don't know why nor do we but we do know that our production costs are lower because we are not bothered with this common disease. 


\section{Apples! King of Fruits!}

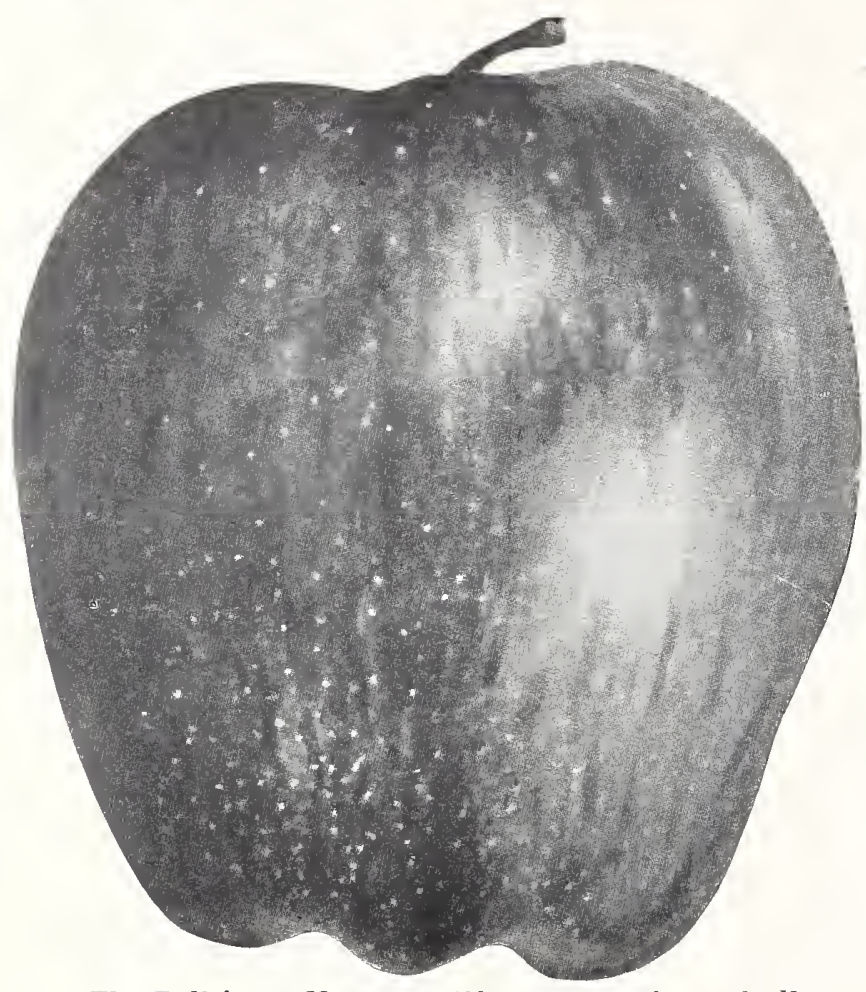

The Delicions-Most Beatiful and euscious of all Winter Apples

\section{Plant Neosho Quality}

\section{The Incomparable Delicious!}

DELICIOUS (Winter)-Who is not familiar with this justly popular apple? Who does not appreciate its unexcelled flavor, its beauty of form and color, its fragrant aroma? It is mild in flavor, crisp and juicy, the best in quality. It is large in size and the five knobs at the blossom end are a distinctive characteristic. In color it varies with climate, soil and management; more or less striped with dark red, often a dark crimson. It finds a ready sale at high prices. The tree is vigorous, hardy and is fruiting in nearly every state.

RICHARED (trade marked) DELICIOUS-A new strain of the Delicious, making greatly increased profits for the commercial grower. See price list.

LIVLAND RASPBERRY (Early Summer)-Beautiful red and yellow apple. Medium size; flesh is snow-white, tender, fine-grained, crisp and juicy. Very good. Tree is a strong, vigorous grower. Bears fourth to sixth year.

MAMMOTH BLACK TWIG-(The correct name is Arkansas. Often confused with Paragon.) A large apple of good quality; a dull green or deep yellow overspread with red; good quality; excellent keeper. Formerly quite extensively planted in middle South and Southwest, but not at present, because it is often a shy bearer. The tree is one of the best, making a fine, vigorous, spreading growth.

\section{OurMost Popular Novelty-Neosho}

\section{Five-in-one Apple}

\section{PLANT ONE IN YOUR YARD}

$\mathbf{W}^{\mathrm{E}}$ have a limited number of apple trees with from 4 to

5 different varieties budded or grafted on as many different branches.

These varieties ripen from early summer to late fallDuchess, Wealthy, Grimes Golden, Jonathan and Deliciousall dependable high grade apples.

You can imagine what a beautiful sight one of these trees will present in bearing.

The only pruning you will need to do is to cut back the side branches about one-half their length, and shorten any roots that are too long.

The white bands around branches in photograph at right indicate where limbs should be cut off when planted.

The top branch and trunk is the Delicious, the other branches are labeled.

These trees are three years old with trunks $11 / 16,3 / 1$ and 1 inch or more thick. See Price List for sizes and prices.

Seven Years of Service

"If I am not mistaken. this makes fiftecin thonsind trees in have loveluht of you in 7 years. Our loalings have been so sutisfactory that it bas heenl pleasure to mention the veosho Nursery to my friends." - Mr. IE. T. Russell, Tennessee.
Best in 30 Years

"I have been planting trees for $\mathbf{3 0}$ sears but the 200 trees I got from sou one year ago last spring made the best srowtl of any $I$ ever planted. Did not lose one tree."A. Won. Gerber, Kamsas. 


\section{For Profit, Plant Varieties Known to Succeed}

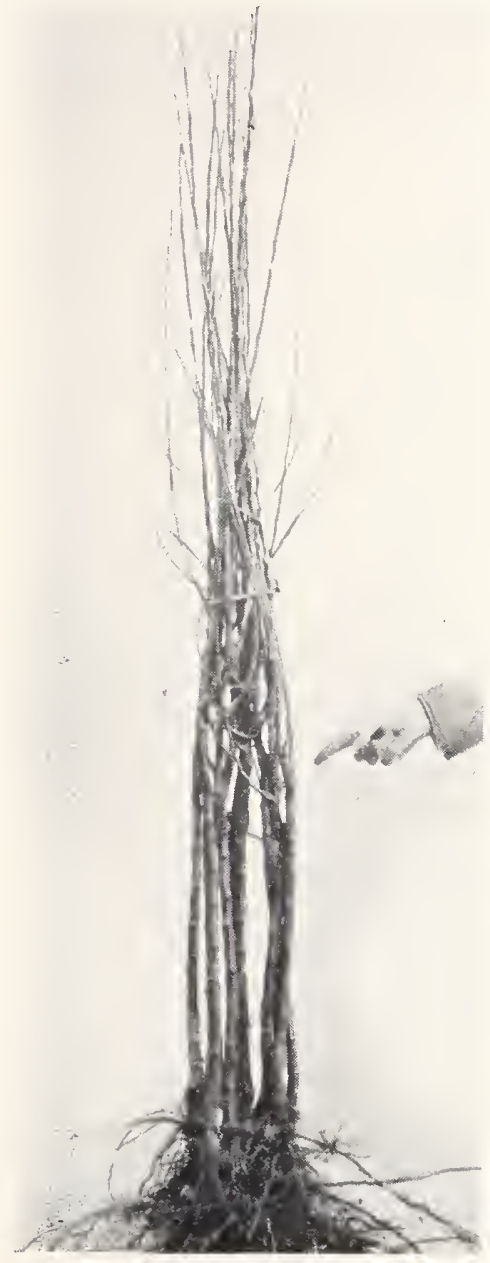

$\mathbf{B}$

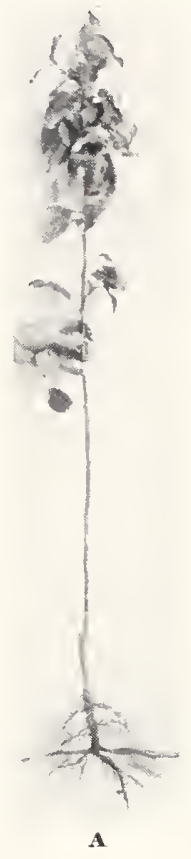

Triple

the

Life of

\section{Your}

Grimes

There are orchards of this variety 15 years old which are dying out on account of collar-rot which attacks the tree near the ground. They will live and retain their usefulness three times as long if the Grimes part is grown on a vigorous variety which is not subject to collar-rot.

In the spring we plant a graft of a hardy variety. Then in midsummer we insert the Grimes bud in the trunk 12 to 18 inches from the ground. (See Fig. A above.) This bud doesn't grow until the following spring when the top is cut off just above the bud. The tree is ready to dig in the fall. The roots and the lower part of the trunk are then two years old. The Grimes part is one year old. (See Fig. B.) Some are whips and some are well branched.

JONATHAN (Fall)-A grand, good apple; once tasted, always wanted. Bright solid red, deep red on the sunny side. Flesh whitish, sometimes tinged with red. Firm, fine, very crisp and tender. It has an aromatic flavor and juice which is full of snap and sparkle. Medium size; very good to best quality. Tree is moderately vigorous, long-lived, an upright grower. Bears about fourth year. Produces good crops regularly. Fine for home and commercial planting.

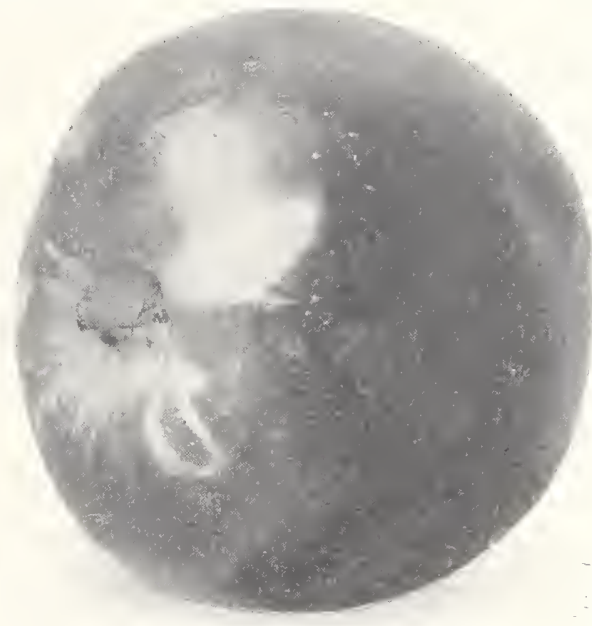

The Beautiful Red Jonathan

The Best Quality Commereial Apple of Its Season.

KING DAVID (Fall)-Enormously productive, bearing heavy crops year after year. Uniform shape, tapering toward the blossom end. Medium size; very dark rich garnet red, showing almost a purplish-black on the sunny side. Similar to Jonathan but more tart. Tree is a hardy, vigorous grower, comes into bearing about the fourth year. Sometimes used as a filler.

GRIMES GOLDEN (Fall)-The standard of excellence, the best quality, profitable yellow apple; rich golden color, often showing a pinkish blush. Flesh is yellow, very firm, crisp but tender, rich, aromatic and juicy; very good to best quality; medium to large; an ideal dessert apple and a splendid cooker. Tree is a hardy, vigorous, upright, spreading grower and heavy regular cropper. Bears about the fourth year. The highest quality yellow apple and one of the best for home use and commercial planting. It is a leading commercial variety in Missouri, Arkansas and is successfully grown in many other middle latitude states. Plant double-worked trees only.

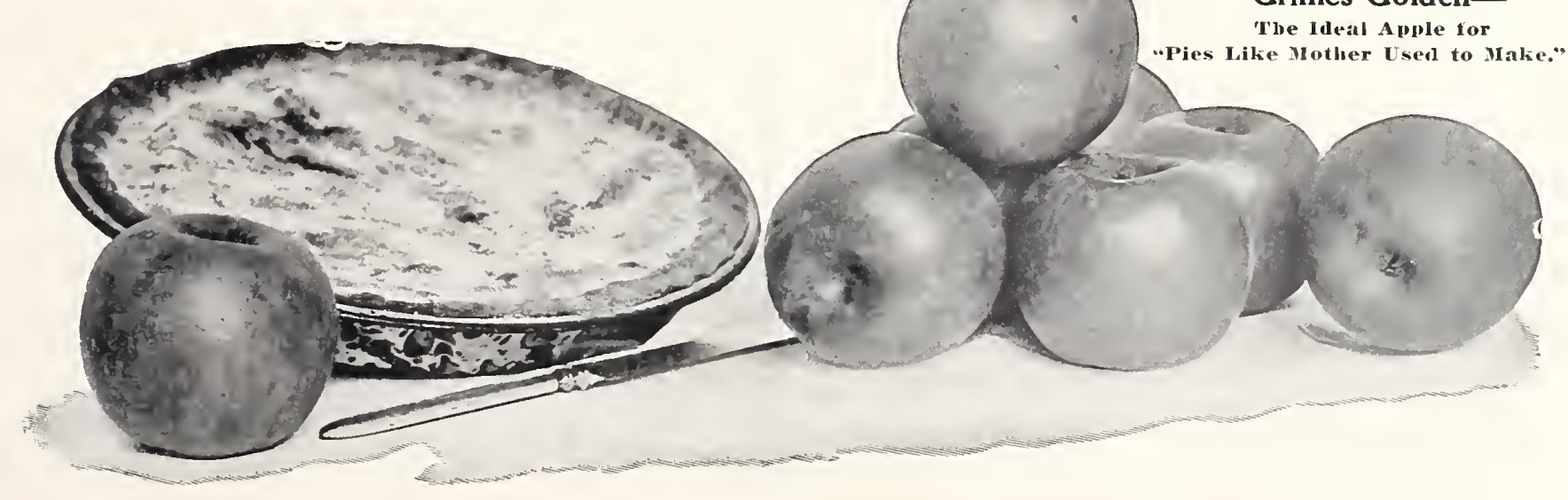




\section{'Your Trees Have Done Better Than Any Others'}

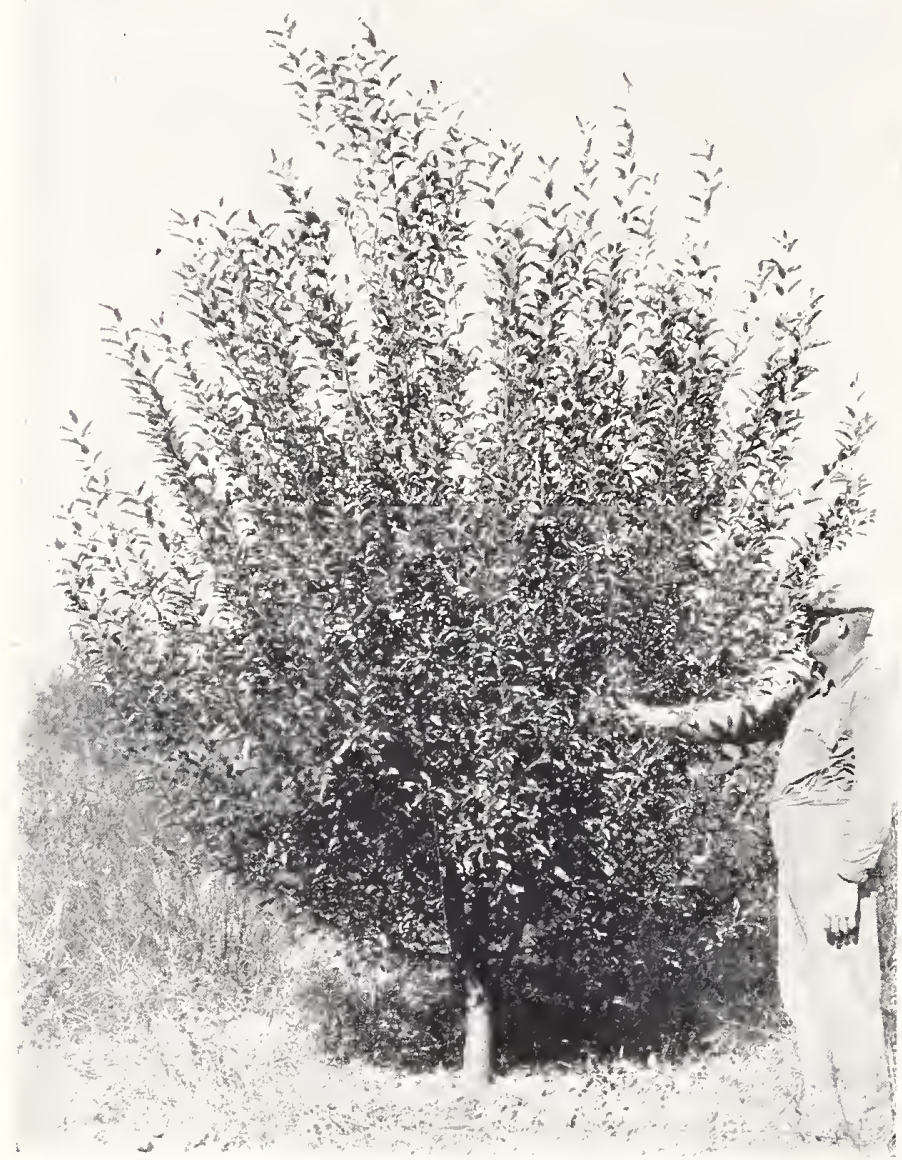

This pieture, taken October 23,1924 , shows one of a thousand one-year Neosho Nurseries Apple Trees planted in the spring of 1920. Mr. A. N. Walker of Neosho, standing by this tree, is nbout 6 ft. 4 in. tall. No wonder he is prond of his orehard.

PARAGON WINESAP (Winter)-Paragon has the large size and very good quality of the Stayman combined with the dark red color of the old Winesap. The true Paragon was introduced and named by Dr. W. L. Moores of Lincoln County, Tennessee, and has been largely planted under name of Mammoth Black Twig, giving the latter an undeserved reputation. Tree is equal in every respect to Winesap; a more vigorous, open grower. Bears sixth to seventh year, and thrives wherever Winesap can be grown.

RED ASTRACHAN (Midsummer) - A general-purpose apple for home use and local market. Nearly covered with light and dark red stripes, overspread with bloom like a plum; large, roundish; white flesh tinged with red; flavor aromatic, brisk, subacid; very good. Good for eating fresh out of hand when fully ripe; an ideal cooker. Tree is hardy, of the Russian type, moderately vigorous, upright, spreading; adapted to every state where apples grow. Bears fourth year.
MAIDEN BLUSH (Late Summer)-Striking, highly colored, yellow apple, with a deep crimson blush on one cheek. Round, flat, medium size; flesh white, crisp, tender, very juicy; a good eating and excellent cooking apple. Tree is vigorous, spreading, and open. Usually bears fourth to fifth year.

McINTOSH (Fall)-One of the best early winter apples for northeastern states; noted for its high quality and delightful fragrance. Medium to large size, roundish, slightly flattened at the stem end. Beautiful deep crimson, striped with carmine and overspread with a heavy blue bloom. Crisp, snow-white flesh; is very tender and juicy, entirely different from "meaty" apples like Spitzenburg and York. Makes a strong appeal to people who pay high prices for fancy fruit. Tree is longlived, a strong, vigorous grower, with an open, spreading head, and very hardy. Bears fourth to fifth year. One of the best apples of its season, both for home planting and to supply not-too-distant markets.

NORTHERN SPY (Winter)-Attractive, red-striped winter apple; large, roundish and plump, tapering slightly toward the blossom end. Flesh is firm, fine-grained, crisp, rich, subacid, very fine quality. It appeals to those who like a brisk, spicy apple that is not actually sour. Tree is a vigorous and unusually healthy grower. Bears seventh to twelfth year. An old-time favorite in the North and Northwest.

RHODE ISLAND GREENING (Winter)-A large, roundish, green winter apple, yellow when fully ripe. Tender and full of sparkling juice, with rich flavor surpassed by few apples. One of the best dessert apples and an excellent cooker. Tree is a large, vigorous grower, with wide spreading branches, drooping and dense, usually late in coming into bearing. A North and Northeastern variety.

ROME BEAUTY (Winter)-Large, roundish, oblong apple, handsomely colored and striped with bright red; one of the most beautiful and profitable late winter apples. Flesh is firm, crisp, juicy and of good quality. Splendid storage apple. Tree is a vigorous, upright spreading grower; hardy, except along the Canadian border. Very profitable in the central United States, Rocky Mountain country, and some Southern states; a splendid bearer, blooms late. Bears fourth to fifth year.

DUCHESS OF OLDENBURG (Midsummer) - Attractive yellow apple, almost covered with red stripes; medium size. One of the most profitable summer varieties. The flesh is tender, juicy, subacid; very good for culinary purposes even before fully ripe. Tree is a moderate grower; can be planted close and is often used as a filler. Comes into bearing young, often fourth year. Bears heavy crops annually; great market apple and especially good cooker. Ripens in succession, requiring several pickings. Extremely hardy.

\section{"A Booster for Neosho Apples!"}

"In the spring of 1925 I purchased 350 apples trees from you and 200 apple trees in the spring of 1927. Each time you furnished me better stock than I had contracted for. My trees have made a wonderful growth and very few have had to be reset."-W. G. Mullins, Mo.
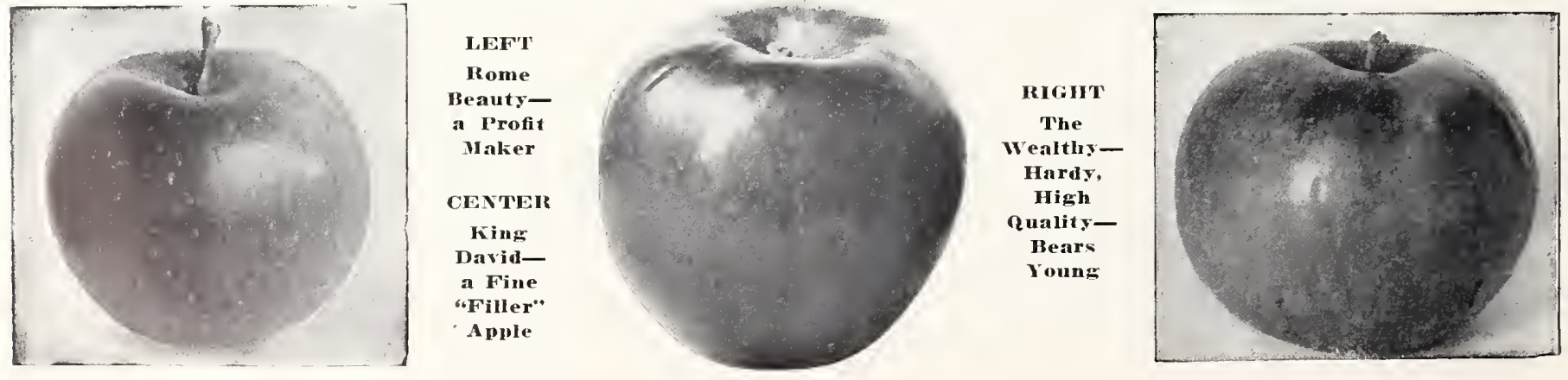


\section{Every Neosho Apple a Tried and Proved Variety}

SENATOR (Oliver-Red) (Winter)-A medium to large, attractive, roundish apple of good to very good dessert quality. Under color yellow, washed over nearly entire surface with bright red and with numerous gray or russet dots. A fall apple in the Ozarks of Missouri usually picked early in September.

SPITZENBURG-(Esopus Spitzenburg) (Winter)-Large, handsomely colored, bright purplish-red, shaded with yellow and striped with darker red; fiesh firm, tinged with yellow; moderately juicy, spicy, very best quality. Tree is moderately vigorous, spreading; a rather moderate cropper. Thrives in favored Northern localities, particularly in the Northwest. Should be planted in deep, fertile, well-drained soil. Bears about the seventh year.

STAYMAN WINESAP (Winter)-The largest of the Winesap family. Striped and splashed with dark crimson, resembling Winesap, except that the color is not quite so brilliant; flesh tinged with yellow, firm, crisp, sprightly pleasant, with a rich subacidity that appeals to everyone. Splendid quality. Tree has a dark, heavy foliage, closely resembling its parent, the Winesap; thrives on thin dry soil where Winesap would fail. Reliable annual cropper; bears the fourth to fifth year. It does best in middle latitudes.

SWEET BOUGH (Midsummer)-A sweet apple, juicy, good to very good for dessert, excellent for cooking. Begins to ripen about the first week in July. Color is a greenish yellow changing to yellowish white.

WAGENER (Fall)-Bright red apple, strongly contrasting yellow background color; medium to large; whitish flesh, tinged light yellow, firm, fine-grained, juicy, very good quality. Tree is straight, vigorous, upright grower; enormously productive, usually bears third to fourth year. Often used as a filler. A Northern variety.

WEALTHY (Late Summer)-A most dependable and widely planted late summer apple; bright red striped; medium to large size; white crisp flesh tinged with red; good for cooking before it ripens. Ripens over a long season. Very good quality. Tree is an upright grower; often used as a filler; very hardy; bears fourth or fifth year. Adapted to many soils and climates, but especially suited for Northern planting where extreme hardiness is required. Good shipper; especially recommended for home use and commercial planting.

WILLOW TWIG (Winter)-Medium to large yellowish green, washed and striped with dull red; flesh yellowish, mild subacid; good quality; a good, long keeper. Tree strong grower, spreading, with drooping willowy branches. Rather early and regular bearer. A semiSouthern variety.

WILSON JUNE (Midsummer)-A deep, solid crimson, like a Red June; large; firm white flesh; good quality. Tree makes a moderately strong growth, is hardy, vigorous, very productive, bears young. Most beautiful of its season; good shipper.

\section{"I NEVER HAD BETTER TREES"}

"The trees I hought of you to plant the 40-acre orehard were fine and I never had trees that made a better growth. I confor sour good treatuent in all our dealings."-H. G, Itichurdsou. (See Illustration Below.)

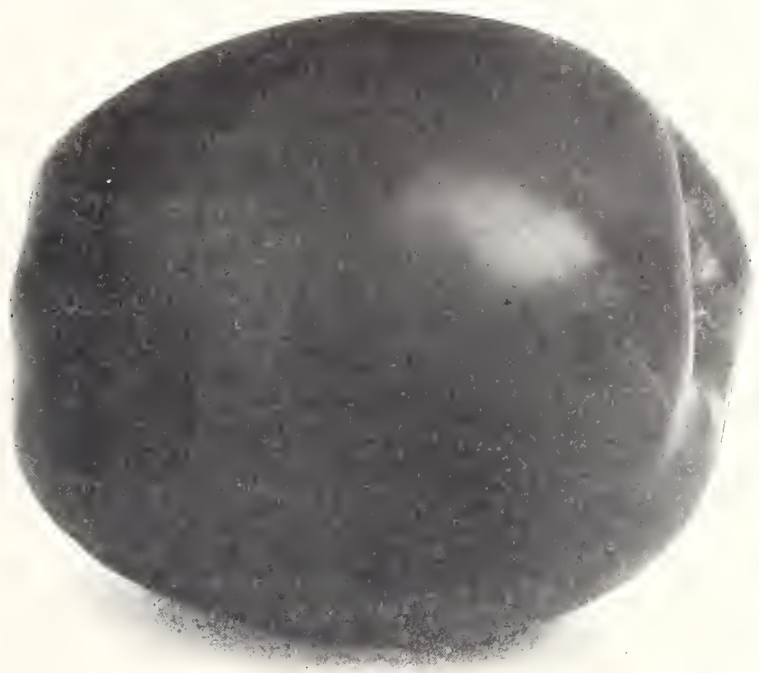

The Big Crimson Wilson June

The Iost beantiful of its season, Good shipper.

WINESAP (Winter)-One of the oldest and most popular apples, a good shipper and an exceptionally good keeper in ordinary and cold storage. Well-grown Winesapa command a premium over most other winter apples with commercial buyers. Splendid bright red, indistinctly striped with dark purplish-red. Flesh is tinged with yellow; very firm, juicy, very good quality. Medium size; a favorite with everyone. Tree is a vigorous, spreading, open grower. Hardy, adapted to planting in every part of the country, except in the extreme Northern states. Will succeed on many different kinds of soils, preferring a deep loam. It is a heavy, regular bearer. Produces the first crop about the fifth year.

WINTER BANANA (Winter) - Very showy, bright yellow, with a pinkish-red cheek; noted for its brilliant, trangparent, waxen appearance; medium size; good quality, with a rich, spicy flavor. Tree is a good average grower, adapted to many conditions; flat, spreading top; hardy, except in extreme North; regular cropper; bears about the fifth year.

EARLY HARVEST (Midsummer)-A pale yellow, medium sized apple of very good quality for either dessert or cooking. The tree is a fairly good grower, medium sized and comes into bearing young. Widely grown for home use.

ADA RED (Late Summer)-Originated in Northwest Arkansas where the only two orchards now in bearing are located and is harvested about August 15. It has not been tested in other districts to our knowledge. It is a particularly early bearer. The fruit is medium size, roundish; yellow, nearly covered with red and broken stripes of purplish crimson; flesh whitish; flavor mild subacid; quality good; good for dessert, excellent for cooking.

ALBEMARLE PIPPIN-(See Yellow Newtown.)

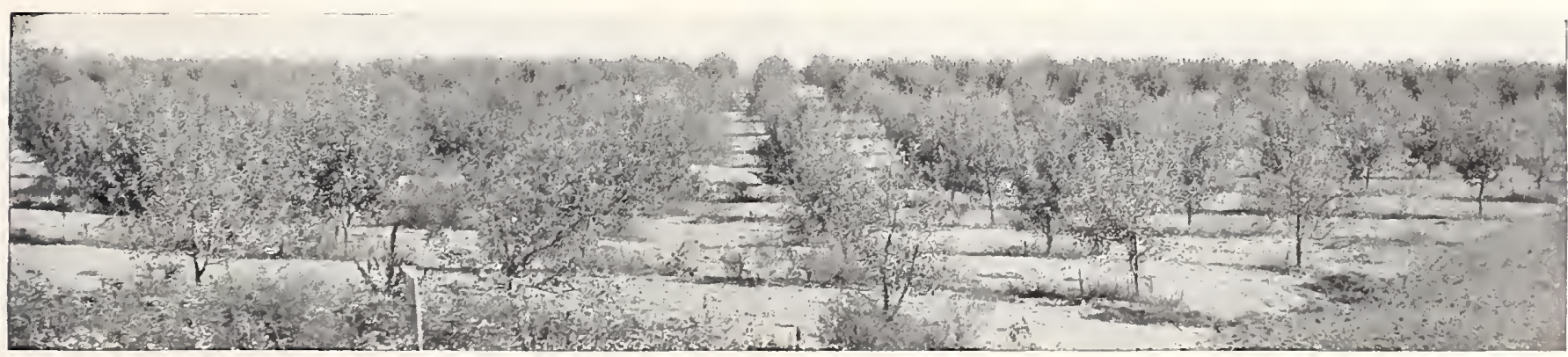




\section{"Your Trees Are Bearing All True-to-Name"}

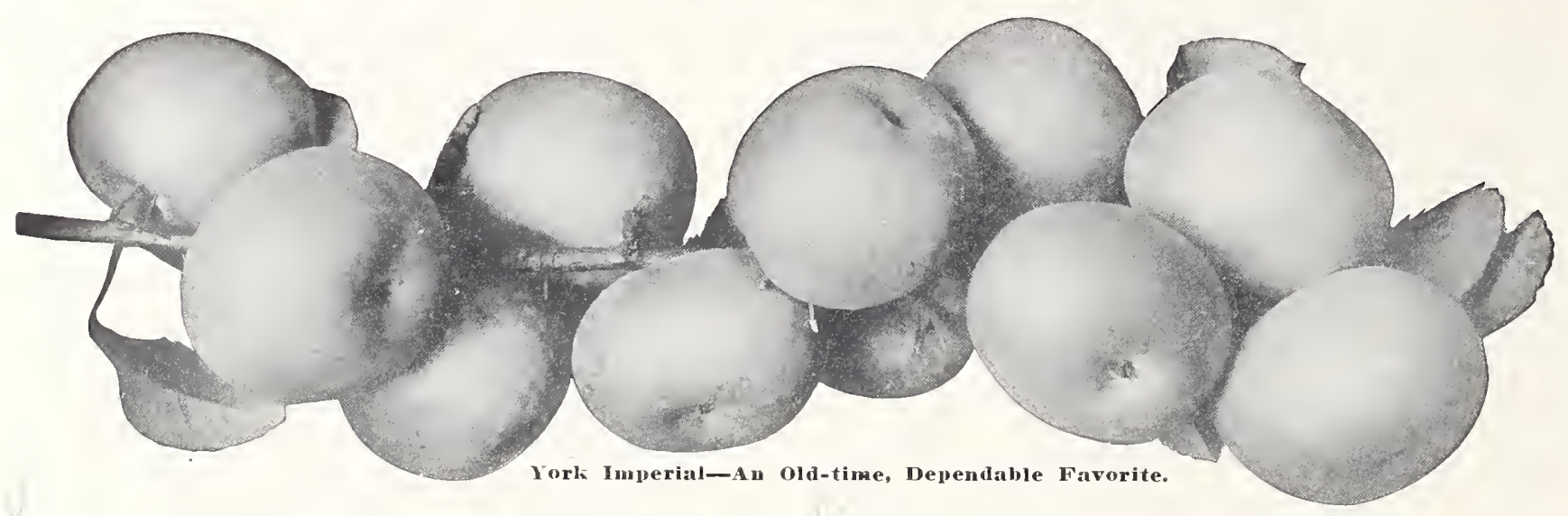

BALDWIN (Winter)-The Baldwin is the leading variety in the commercial orchards of New York, New England, and certain parts of Canada; also in Michigan and Northern Ohio. In the South and Southwest it is not desirable, because it ripens too early, and drops from the trees before its good qualities are developed. It does fairly well in the Pacific Northwest, but cannot be grown in competition with the Northeastern States. The tree is a strong grower, long-lived, and vigorous. It is somewhat slow in reaching maturity, but usually begins to bear abundantly about the seventh year. Fruit large to very large, uniform in size; form, roundish to conical; skin is tough and smooth, blushed and mottled with bright red; flesh yellow, firm, moderately coarse, crisp, tender, juicy, agreeably subacid, good quality.

BLACK BEN (Winter)-The best of the Ben Davis family. It attains a much higher color than the Ben Davis or Gano. The tree is hardier, more vigorous, and more prolific than the Ben Davis. Bears about the sixth year; fruit is large, solid dark red; flesh is white, firm, juicier than Ben Davis, mild subacid, fair quality. It is preeminently successful in Virginia, Kentucky, Tennessee, Illinois, Missouri, Arkansas, and portions of adjoining states.

CHAMPION (Collins Red) (Winter)-Tree hardy, very heavy, regular and early bearer. Fruit medium in size, roundish; attractive deep red striped with purplish carmine, but when not fully colored is yellow striped with red; picking season, Southwest Missouri, mid-October. Comparatively low quality but good for such a late keeper. Cold storage limit May or June. Sells well on Southern markets.
YELLOW NEWTOWN (Albermarle Pippin) (Winter)Medium to large; a beautiful yellow; flesh very firm, meaty, britćle, juicy; highest quality for dessert and excellent for culinary purposes. Tree is a good grower, but must have fertile soil. Hardy; bears the fifth year. It is firm, keeps very late and ships well. Grown chiefly in California, Oregon, Washington and Virginia.

YELLOW TRANSPARENT (Early Summer)-One of the best extra early apples; extremely hardy; a beautiful clear yellow, with smooth waxen, brilliant skin, which gives it a transparent appearance. Fine-grained white flesh, sprightly, subacid, pleasant. Unexcelled for pies, tarts and apple sauce. Medium size. Tree is a moderately vigorous. straight, upright and compact grower; often used as a filler; usually bears third to fourth year. A reliable cropper. Fruit ripens over a period of three weeks and requires several pickings. Profitable for near-by markets. Excellent for home planting.

It is adapted to all apple soils and climates. One of the best apples for the South, and is very extensively planted in the North because of its unusual hardiness. It will sometimes blight like the pear if planted on soil that is too rich and the growth forced too much by fertilization. Succeeds on thin soils.

YORK IMPERIAL (Winter)-Bright, pinkish-red, striped with dark-red; firm, crisp, meaty flesh, brittle, a little coarse, but juicy and fair quality. Large; its oblique or lopsided shape is a notable characteristic. The tree is of ideal shape, a very strong, vigorous grower and enormously productive; planted in the middle Atlantic States and Central West. A very regular bearer, beginning about the seventh year; seldom fails.

\section{Crabapples-Every Home Should Have One}

CRABAPPLES should be planted for beauty of tree and fruit, as windbreaks, and for the value of the fruit. They are delicious for cooking, preserving and jellies. Excelsior is delicious for eating fresh.

EXCELSIOR (Fall) - Very large for a crabapple, nearly as large as a medium sized apple. Very attractive yellow almost covered with bright red. Flesh is white, juicy, subacid, excellent in quality for dessert and for culinary uses. Tree is good, strong grower; hardy, healthy; comes into bearing rather young, and bears good crops alternate years.

FLORENCE (Late Summer)-Medium size, yellowish-white, mostly overspread with brilliant pinkish red. Flesh tinged with yellow, juicy, quite subacid, somewhat astringent. Tree is moderately vigorous; at first upright spreading but eventually inclined to droop. Bears very young, is very productive, reliable cropper and the fruit is of good size, very attractive and good quality.

HYSLOP (Early Winter)-LLarge, very brilliantly colored, dark red or purplish, overspread with thick blue bloom. Tree is a good grower, very hardy, reliable bearer, usually biennially. Flesh yellow, subacid, astringent; good for culinary purposes.

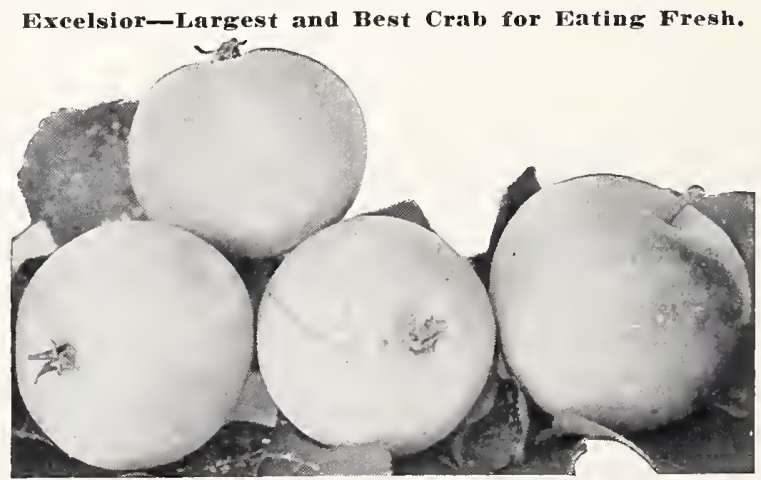




\section{Home Grown Cherries Are Finest!}

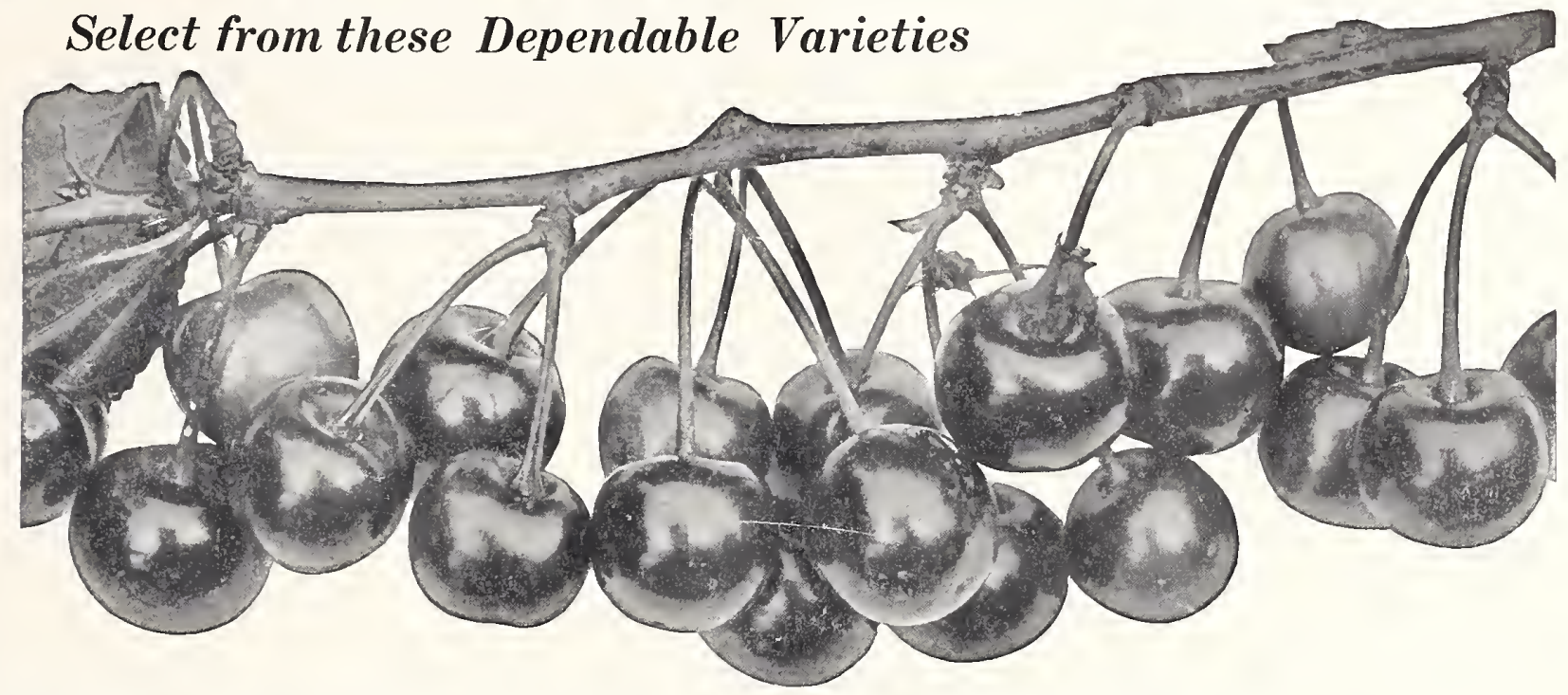

YOU may buy cherries fresh or canned; but if yo u ever tasted any fresh and ripe from the tree, you 1 will surely want a few trees of your own. Possibly you cannot grow sweet cherries, since they thrive only in favored localities, preferring a sunny, equable climate and a deep, dry, gravelly or sandy loam; they also require particular attention and care, especially in spraying. But the sour cherry can be grown almost anywhere. It is notably hardy and quite adaptable to different soils and climates, preferring a moderately heavy loam. The soil must be well drained. It does better under neglect than any other tree fruit. The three leaders-Early Richmond, Montmorency and English Morello-ripen over a season of nearly forty-five days. The sour cherry makes a fine ornamental windbreak, gives great satisfaction in the home garden and offers great possibilities for profit for the grower who supplies local markets. Plant some Neosho Cherries this year-Look over these popular varieties.

\section{Sour Cherries--Dependable Varieties}

EARLY RICHMOND (Sour)_The favorite early sour cherry, and next to the Montmorency the most popular of all cherries. Fruit is medium size, roundish shape, flattened at the end; flesh light color, tender, and sprightly. A good canner, but not so firm as Montmorency. Tree is medium size, vigorous, upright, spreading, productive and long-lived. Ripens about a week earlier than Montmorency.

MONTMORENCY (Sour) - The most widely and most numerously planted cherry. It is the most productive and regular bearer. Colors early before ripe-a distinct advantage for shipping. The fruit is roundish, plump, flattened at the end, and a beautiful glowing red. It hangs in clusters, making picking easy.

The fruit does not crack or rot even in very hot, rainy weather. It hangs on without dropping after it is dead ripe. The flesh is rich, sprightly, and pleasant; flesh is reddish color, tender, and melting, but firm. A good shipper and a good canner. Does not mash down in the box.

The tree is the largest, most vigorous grower of all the sour cherries. Round, spreading, upright head, especially hardy and productive; a very reliable cropper. Bloom is hardy and seldom injured by late frost or severe winter freezes. The Montmorency can be grown in practically every part of the country except the low lands of the extreme South. Adapted to great variety of soil and climate and succeeds well under adverse conditions. Ripens in Southwest Missouri first week in June.

ENGLISH MORELLO (Sour)-Fruit is small, dark red colored, very sour, but loses much of its sourness if left on the tree until fully ripe. First-class for canning and preserving. Stands lower temperature and severer drouth than any of the other leading varieties. Tree is small, round-headed with drooping branches. Bears young. Very productive and hardy but not as healthy nor adanted to many different kinds of soil as Montmorency or Early Richmond. Especially good for gardens where a snzall-growing tree is desired.

\section{If You Prefer Sweet Cherries}

A sweet cherry planted alone is not likely to bear fruit because it is self-sterile. Plant a Black Tartarian with any other sweet cherry.

BING (Sweet)-Very dark red, almost black; very large; very good quality; ripening midseason; blooms early.

BLACK TARTARIAN (Sweet)-Most widely planted sweet cherry east of the Mississippi. Beautiful, lustrous, purplish-black when ripe. Medium size for sweet cherrv. Flesh purplish-red, firm, tender, pleasant flavor, sweet and mild; very good quality. The tree is a very large, vigorous, upright grower; adapts itself to widely different soils and climates. Very productive and regular bearer. Comparatively free from brown rot. Early.

GOV. WOOD (Sweet)-Yellowish-white tinted with crimson; large; very good quality; ripening early, with Black Tartarian; blooms early.

NAPOLEON (Sweet)-The best yellow cherry. Often sold and grown as Royal Ann. Best of the sweets for dessert and canning. Very particular as to soil and climate. Apt to crack in wet weather, and somewhat susceptible to brown rot. Nevertheless, it deserves first place among sweet cherries for home and commercial planting. It is an attractive yellow, with a bright red cheek; very large; long, heart-shaped; firm flesh. Meaty, crisp, mild and sweet; high quality. Tree is a hardy, vigorous, upright grower, with strong, sturdy limbs. Very productive and bears young.

WINDSOR (Sweet)-Dark red, almost black; large; good to very good quality, ripening late; blooms early; very hardy; upright grower.

\section{"Best One Year Trees I Ever Saw!"}

"I have been buying trees the wast ten years and this lot is the best one-year trees $I$ ever saw. I have 70 aeres in trees." -Irwin Paul, Miehiora. 


\section{Peaches-None Equal Home-Grown in Flavor}

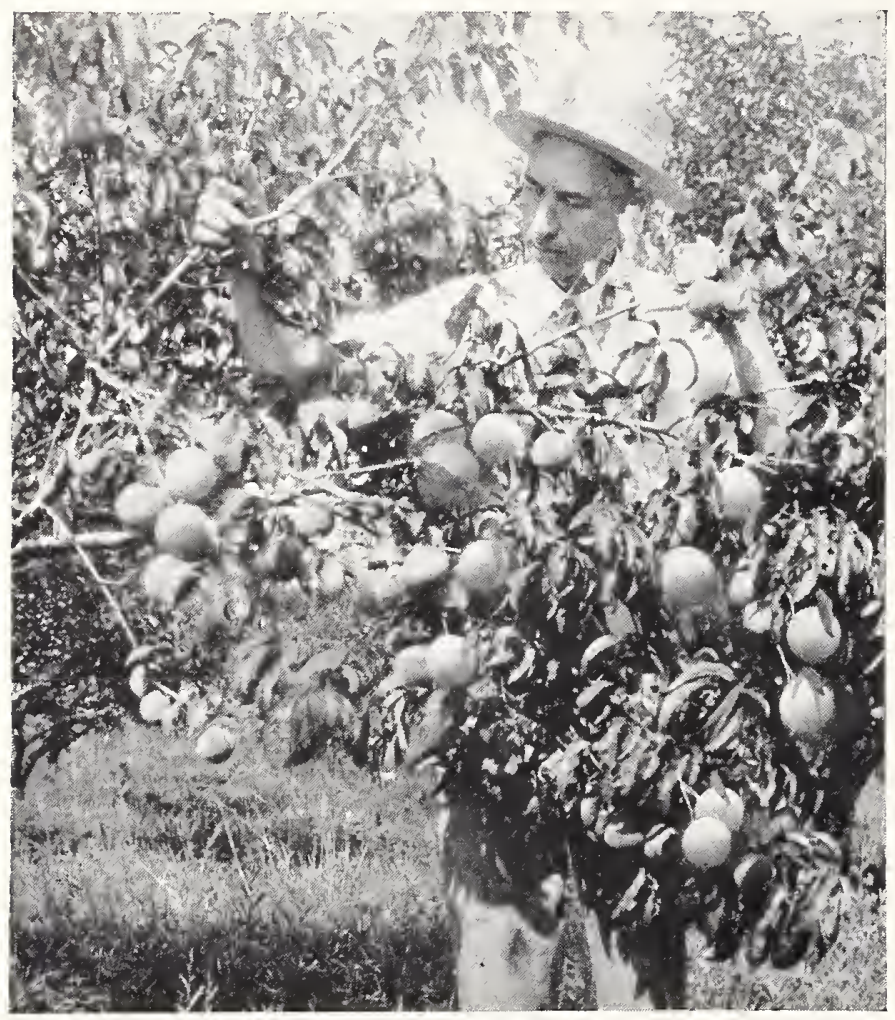

T $\mathrm{T}$ is not at all hard to have fine, abundant bearing 1 peach trees like this one on J. L. 'Taylor's farm in Kansas. He is another one of the thousands of satisfied Neosho customers.

ALTON (White Semi-Freestone) (Midseason)-A large, handsome white-fleshed peach of good quality. Tree is hardy and productive. Blooms early. Grown mostly in Middle West and South.

ARP BEAUTY (Yellow Semi-Clingstone) (Early)-The earliest good yellow peach. Round-oval in shape, heavily blushed with red, excellent quality. Deserves a place in every home orchard. Tree is vigorous, productive, hardier in bud than the average.

BELLE OF GEORGIA (White Freestone) (Midseason)-An unusually handsome large peach. Creamy-white blushed with red, good quality. Tree is large, open headed, hardy. Prefers a Southern or Semi-Southern climate.

CARMAN (White Semi-Freestone) (Early)-A very general favorite in nearly every peach section as it succeeds in a great variety of soils and withstands trying climates. Tree is an excellent grower, bears abundantly, remarkably hardy in wood and bud. Fruit is brilliant red, splashed with darker red on creamy-white background; good quality for its season.

CHAMPION (White Freestone) (Midseason)-An exceptionally high quality, attractive, hardy white peach. It has a peculiar honeyed sweetness. Not a good shipper but ideal for home use and local markets.

CROSBY (Yellow Freestone) (Late)-Most notable for hardiness of tree and bud. Tree is rather small grower but unusually vigorous, healthy and productive. Fruit is medium size, not attractive, but very delicious for dessert or culinary use.

EARLY ELBERTA (Yellow Freestone) (Midseason)-Very large, high quality, lemon-yellow peach; originated in Utah. Flesh is fine grained, sweet; for home use and local market. Tree is a strong grower of Elberta type. A good bearer under favorable conditions; moderately hardy.
$\bar{G}$ RESH, ripe, home-grown peaches over a season 7 of nearly three months are a most delicious fruit that may be had at little expense. You can never know how good peaches taste until you pick them fully ripened from your trees. They can be grown almost as far north as apples and will succeed farther south. They will do well on a wide range of soil types, even moderately heavy clay loams and clay, but the soil must be well drained. The soil should be moderately fertile. Peaches will not do well on hard impervious clay nor on very alkali soils. Plant largely of midseason and late varieties, but include enough of the earlier and very late kinds to provide an ample supply throughout the season.

ELBERTA (Yellow Freestone) (Midseason)-The most widely and extensively planted commercial peach. Very large golden-yellow, nearly covered with crimson on the sunny cheek; flesh is firm, rich yellow, fair quality. Tree is a moderately vigorous grower, very productive, yielding large quantities of uniform, highly colored fruit, mediocre in quality; moderately hardy in wood and bud, but its adaptability to all soils, its prolific bearing, large size, splendid shipping qualities, and the tendency to color well before fully mature have made it the great market peach.

ELBERTA CLING (Yellow Clingstone) (Midseason)-The best yellow clingstone; especially fine for canning, preserving and pickling; large, yellow, round, good for dessert. Tree is a strong, vigorous grower, hardy and productive.

GREENSBORO (White Semi-Freestone) (Early)-A leading early white peach, owing to its showy fruits and its large, vigorous, healthy trees which are early-bearing and exceptionally prolific. It thrives in a great variety of soil and climates. Somewhat inferior in quality; a good shipper and keeps long.

ILLINOIS (White Freestone) (Midseason)-A very handsome large peach of good quality, sweet and juicy. Ripens about same season as Champion. We grew 500 trees for a Missouri customer who considers them the best variety for local market. Not as widely adapted as the Champion.

KRUMMEL (Yellow Freestone) (Very Late)-A large, round peach, one side a little larger than the other. A rich golden yellow, blushed with carmine. Flesh is yellow, tinted red at the pit. Firm, melting, rich, subacid, and refreshing. Good quality. A good keeper and shipper. The tree is hardy, healthy and a strong, vigorous grower. It is hardier and more productive than Salway. "The latest peach grown at the station. Ripened October fifth."-Ohio Exp. Station.

\section{One Season's Growth}

orchard of Peach Trees from Neosho Nurseries at osceola, Ark.

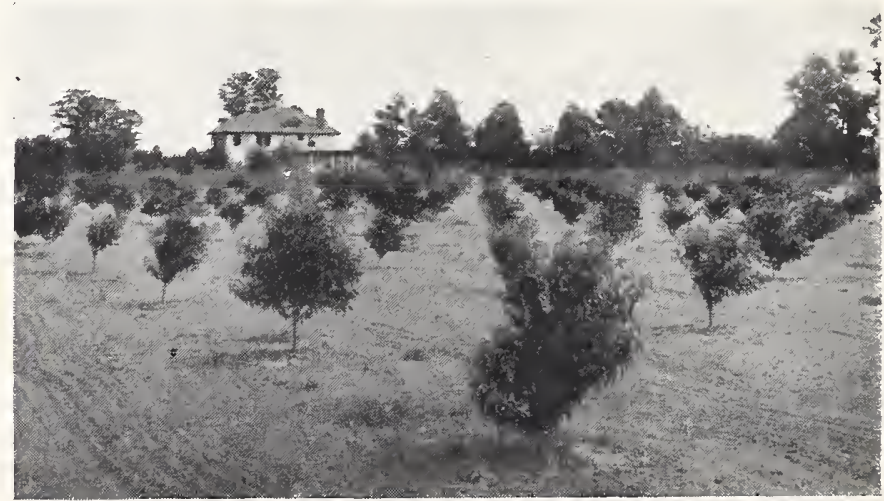




\section{Plant Our Erose For Delicious Early Peaches}

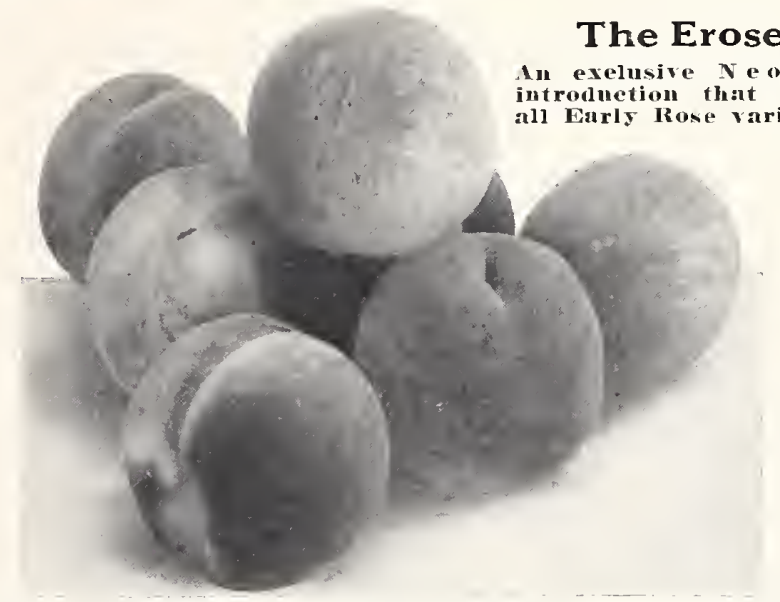

LATE CRAWFORD (Yellow Freestone) (Late)-Its high quality, scarcely equaled in richness of flavor, its adaptability to a wide range of soil and climatic conditions make this old variety exceptionally desirable for the home garden. The trees are vigorous, hardy and healthy and the fruit large and very handsome.

MAYFLOWER (White Semi-Clingstone) (Very Early)Earliest peach to ripen. Good size and quality for such an early variety. Creamy white with dark splashes of red; very juicy; fruit ripens unevenly through a long period, making it especially good for home use. Tree is vigorous, upright, spreading and bears very young.

ROCHESTER-Large, yellow freestone with very sweet, delicious flavor. Keeps and ships well. Strong grower, hardy; bears young and regularly.

HEATH CLING (White Clingstone) (Very Late)-The best of all peaches to preserve or pickle whole. The tree is unusually large, healthy and hardy. Exceptionally good keeper, has been known to keep from Oct. to Dec.

HILEY (White Freestone) (Midseason)-Hiley is the earliest commercial freestone white-fleshed peach; better in quality than most of its competitors; very closely resembles its parent, Belle of Georgia. Flesh is firm, sweet, good quality; a very good shipper; often requires several pickings. Tree is medium size, open, spreading. Productive, but not particularly hardy nor vigorous.
EROSE (Early Rose) (Red and White Clingstone) (Early)There are several varieties under the name Early Rose. To distinguish ours we are renaming it Erose. This peach originated in Georgia and was introduced by us. It has a delicious sweet flavor, red flesh, medium size and ripens about a month earlier than Elberta. The tree is a medium grower and can be planted closer than such large growing sorts as Belle of Georgia and Carman. Bears young. Most early varieties lack in quality which makes Erose even more appreciated.

EARLY ROSE-(Name changed to Erose. See above.)

J. H. HALE (Yellow Freestone) (Midseason)-This variety was discovered by J. H. Hale over 20 years ago. He sent the fruit from Georgia in an ordinary barrel packed like potatoes to Neosho, where they arrived in splendid condition. Very large in size; it is a beautiful yellow overlaid with red, and has a firm, fine grained yellow flesh of good quality. It colors up a week before maturity, ripens 3 to 7 days ahead of Elberta. The tree is more stocky than the Elberta. It should be planted with some other variety for pollination.

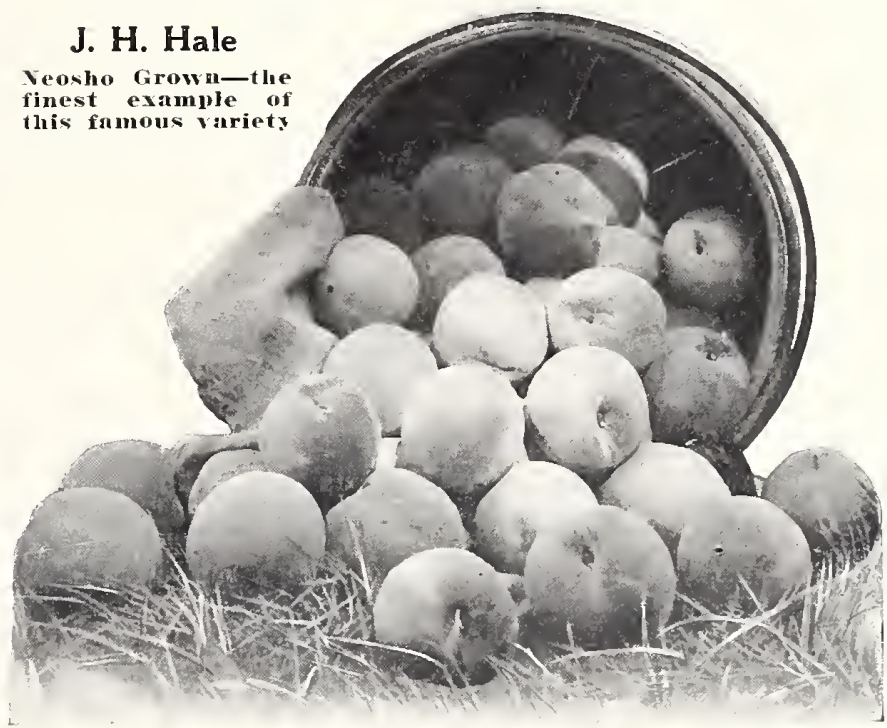

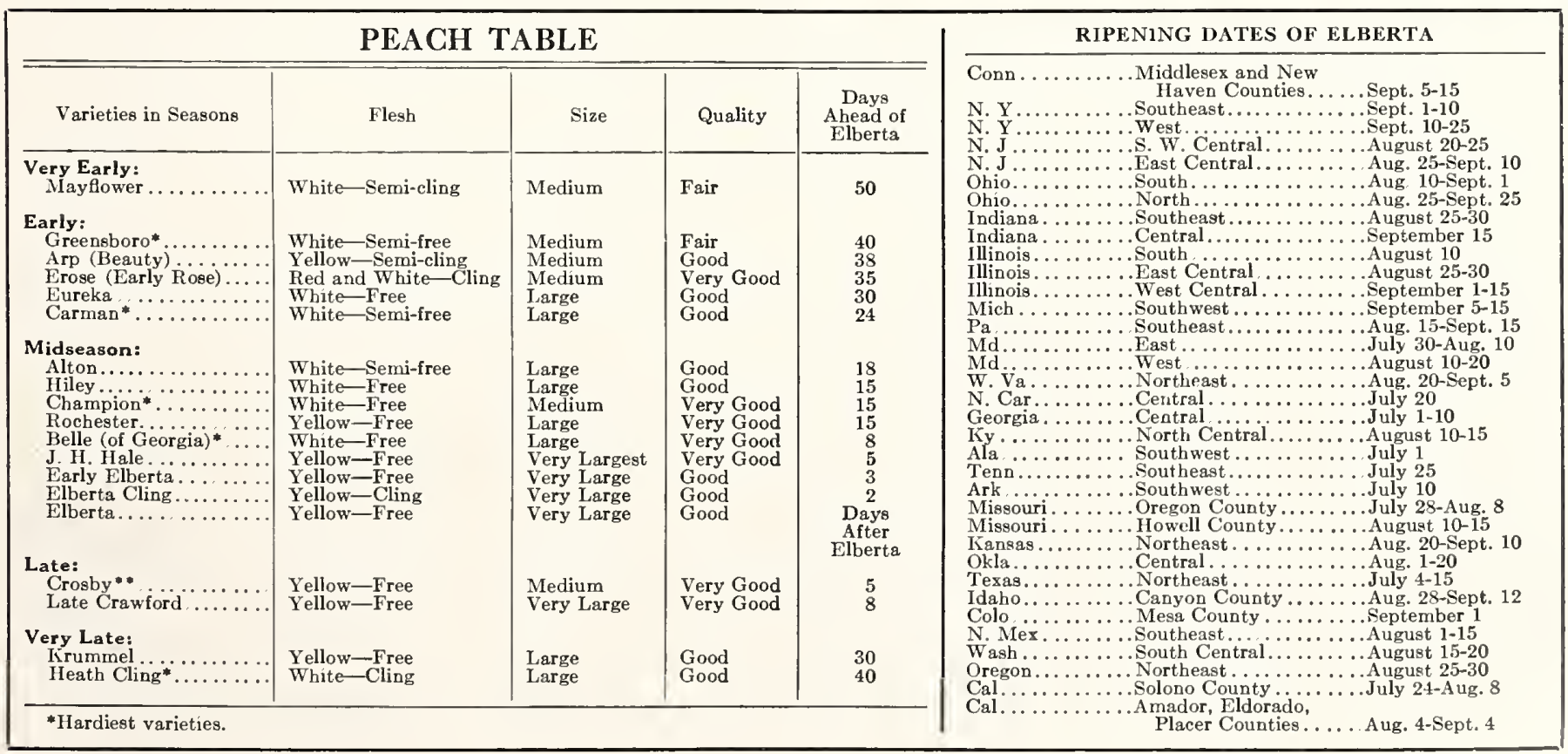




\section{Plant a Few Pears in Your Yard}

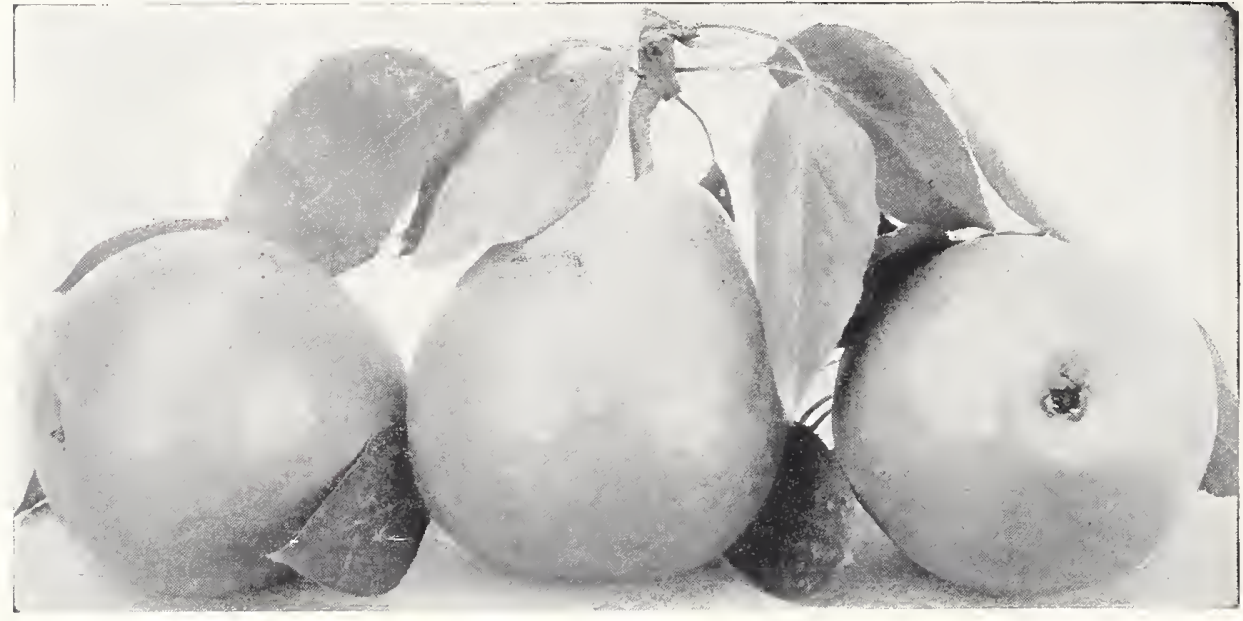

SECIKEL-A Small Golden Russet Pear-Sweetest of All
7 HE Pear is one of the highest quality fruits. All pears should be picked before entirely ripe, especially Garber and Kieffer, otherwise the flesh around the core becomes coarse. Pears may be grown wherever apples succeed. They prefer heavy clay and clay loams and on such soils the growth is slower and there is less danger of blight. As a rule, growth should not be stimulated, certainly not with manure. The pear tree is an upright grower and thrives in sod, making it one of the best fruit trees for yard planting.

\section{Standard Pears}

"Standards" are pears that are propagated on pear roots.

ANJOU (Fall)-Fruit is large, heavy, greenish-yellow with dull red cheek often russeted. Very good quality and keeps late. Tree is hardy, long-lived, productive. Tardy in coming into bearing.

HARTLETT (Late Summer)-The leading commercial variety, one of the most popular for dessert and canning. Large, fine-grained, juicy and sweet Tree is vigorous, very productive, hardy, bears young.

FLEMISH BEAUTY (Farly Fall)-Large, pale yellow, mostly russeted. Very juicy and sweet. One of the choicest when well grown.

GAIRER (Fall)-Large, brownish-yellow with red on sunny side; flesh firm, granular, juicy and poor quality. Used for canning. Succeds farther South where other varieties do not thrive.

KIEFFER (Winter)-Large, yellow russeted; flesh white, rather coarse, poor quality. A market and kitchen variety that succeeds farther south where other varieties fail. If picked when it takes on a slight yellow tint and placed in boxes in a dark place to ripen, they are good to eat out of hand and superior to most pears for canning. Tree hardy, very vigorous, resistant to blight. Blooms early.

LINCOLN (Summer)-Large, yellow, quality good to very good, similar to Bartlett, but more resistant to blight. succeds farther south than Bartlett can be grown. It has stood the severest tests of intense, moist, summer heat, and low altitude of the climate at Lincoln. Illinois, where it was originated by w E at Lincoln. Illinois, bearing early and bears heavy crops annually; very hardy. Bearing early and
SECISEL (Fall)-The standard of excellence for quality. Small, yellowish brown with russety red cheek; should first choice for family orchard. Slow grower, depend able, productive and very hardy, notably free from blight. Bears about fourth year. Blooms midseason.

WINTER NaLIS (Winter)-The latest, best leeping pear. Can be held in cold storage until spring. Medium-sized. roundish, yellow, russeted pear with a short, heavy neck. Flesh fine-grained, sweet, aromatic a very good quality. Tree is hardy, has wide adaptability, and is a regular bearer. A slender, straggly grower. Blooms late.

\section{Dwarf Pears-Beautiful and Useful}

THE Pear can be grown more satisfactorily as a $d w a r f$ than other fruits, especially good for planting in small yards and gardens. It is propagated on quince roots, which make the tree a slow, dwarfish grower, and less subject to blight than standard pear trees. The fruit is the same as that of standard trees. They come into bearing young, often in the second or third year and are very productive. "It is the common belief that dwarf pears are short-lived but this is not necessarily true." - Prof. W. L. Howard.

They can be set close together usually 10 to 15 feet apart hence they small yards, where they are ornamental as well as useful. They should be planted 4 or 5 inches deeper than they stood in. the nursery row. Since they should never be more than $1 \%$ feet tall it is often necessary to remove one-half to two-thirds of the annual growth late each winter.

DUCHESS d'ANGOULEME (Fall)-Best when grown as a dwarf. The largest of the good pears; white flesh, rich, good quality. Tree is hardy, upright orower, productive and long lived.

A NJOU, BARTLETT and SECKEL can be furnished as dwarf trees, For descriptions, see Standard Pear.

\section{Picking, Ripening and Storage Dates for Pears}

\begin{tabular}{|c|c|c|c|c|c|c|}
\hline \multirow{2}{*}{ VARIETIES } & \multicolumn{3}{|c|}{ IN NORTHERN STATES } & \multicolumn{3}{|c|}{ IN SOUTHERN STATES } \\
\hline & When to Pick & $\begin{array}{c}\text { When Ripe } \\
\text { Enough to Eat }\end{array}$ & $\begin{array}{c}\text { Latest Cold } \\
\text { Storage Limit }\end{array}$ & When to Pick & $\begin{array}{l}\text { When Ripe } \\
\text { Enough to Eat }\end{array}$ & $\begin{array}{l}\text { Latest Cold } \\
\text { Storage Limit }\end{array}$ \\
\hline 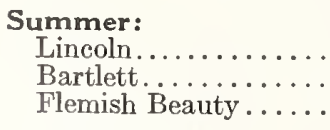 & $\begin{array}{l}\text { July 29-Aug. } 18 \\
\text { Aug. 4-Sept. } 17 \\
\text { Aug. 6-Sept. } 20\end{array}$ & $\begin{array}{l}\text { Aug. 29-Sept. } 8 \\
\text { Sept. } 10-20 \\
\text { Sept. }\end{array}$ & $\begin{array}{l}\text { Sept. } 15-25 \\
\text { Oct. } 1-15\end{array}$ & $\begin{array}{l}\text { July 19-Aug. } 8 \\
\text { July 24-Sept. } 7\end{array}$ & $\begin{array}{l}\text { Aug. 19-31 } \\
\text { Sept. 1-10 }\end{array}$ & $\begin{array}{l}\text { Sept. } 5-15 \\
\text { Oct. } 1-15\end{array}$ \\
\hline $\begin{array}{l}\text { Fall: } \\
\text { Garber.............. } \\
\text { Anjou.... } \\
\text { Duchess d'Angouleme. } \\
\text { Seckel.............. }\end{array}$ & $\begin{array}{l}\text { Sept. } 4-26 \\
\text { Sept. } 15-20 \\
\text { Sept. } 16-25 \\
\text { Sept. } 17-\text { Oct. } 3\end{array}$ & $\begin{array}{l}\text { Oct. } 6-20 \\
\text { Oct. } 20-30 \\
\text { Oct. } 20-30 \\
\text { Oct. } 6-15\end{array}$ & $\begin{array}{l}\text { Dec. } 1-15 \\
\text { Dec. } 15-25 \\
\text { Dec. } 15-25 \\
\text { Dec. } 15-25\end{array}$ & $\begin{array}{l}\text { Aug. } 26-\text { Sept. } 16 \\
\text { Sept. 5-10 } \\
\text { Sept. } 6-15 \\
\text { Sept. } 7-23\end{array}$ & $\begin{array}{l}\text { Sept. } 26-\text { Oct. } 10 \\
\text { Oct. } 10-20 \\
\text { Oct. } 10-20 \\
\text { Oct. } 15-25\end{array}$ & $\begin{array}{l}\text { Nov. } 10-25 \\
\text { Nov. } 25 \text {-Dec. } 25 \\
\text { Nov. } 25 \text {-Dec. } 5 \\
\text { Nov. } 25 \text {-Dec. } 5\end{array}$ \\
\hline $\begin{array}{l}\text { Winter: } \\
\text { Kieffer.......... } \\
\text { Winter Nelis...... }\end{array}$ & $\begin{array}{l}\text { Sept. } 26 \text {-Oct. } 7 \\
\text { Oct. } 3-20\end{array}$ & $\begin{array}{l}\text { Oct. } 25 \text {-Nov. } 4 \\
\text { Nov. } 6-15\end{array}$ & $\begin{array}{l}\text { Jan. 1-15 } \\
\text { Feb. 1-Mar. } 1\end{array}$ & $\begin{array}{l}\text { Sep } .16-27 \\
\text { Sept. } 23-\text { Oct. } 10\end{array}$ & $\begin{array}{l}\text { Oct. } 15-25 \\
\text { Oct. } 15-26\end{array}$ & $\begin{array}{l}\text { Dec. 1-5 } \\
\text { Jan.-Feb. }\end{array}$ \\
\hline
\end{tabular}




\section{Grapes for Pleasure and Profit}

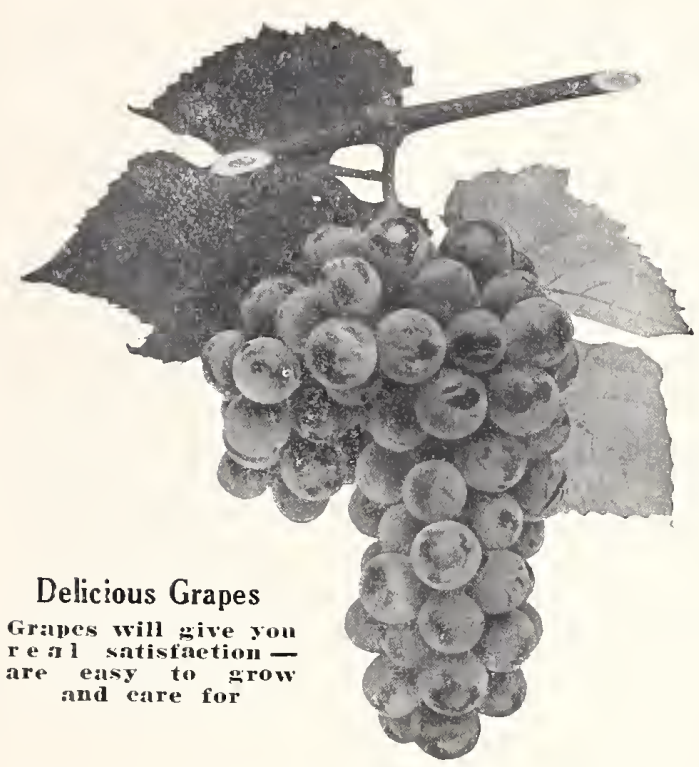

THE GRAPE is the surest, most dependable of fruitsI hardy, vigorous, productive-and begins to bear the second or third year. Every yard or garden should have a few grapevines. They take little room, are quite ornamental trained over arbors, fences, walls or buildings, and they also produce good fruit in spite of neglect or unfavorable conditions. Of course, they respond quickly to care and attention; especially do they require severe pruning. Some varieties are sterile (marked *) and must be planted near others for cross-pollination.

If the soil is poor or not well drained, the home grower can easily provide a remedy. There are vines still bearing at least 300 years old. It is worth while then if necessary to dig a generous hole 2 feet deep, put a pailful of old bones in the bottom, cover them with good earth and plant the vine.

\section{How to Plant Grapes for Greatest Success}

Grape vines are usually planted in the spring. If set in the fall, mulch them heavily or mound the dirt up over the top to prevent injury from alternate freezing and thawing. This mulch or dirt must be removed in the spring. Set $8 \mathrm{ft}$. apart in rows $10 \mathrm{ft}$. apart. Cut back the roots to 6 or 8 inches and plant the vine so the lowest bud is just above the ground. Press good soil firmly about the roots. Cut off all but one cane and prune it back to leave only two buds. Frequent and thorough cultivation is necessary. (See page 41.)
AGAWAM (Red)-The most widely grown of the Rogers Hybrids. Bunches are large. Berry is large, rich, sweet, and aromatic. Vine is vigorous and self-fertile, but does not yield well in some localities. Ripens after Concord and can be kept much longer, and improves in flavor. Seems to prefer clay soil. of the red grapes, it is the easiest grown and most dependable. For home use and market. Keeps in storage till midwinter. Blooms rather late.

BRIGHTON* (Red)-A handsome high quality red grape; clusters and berries are large. Vigorous, productive, dependable, adaptable to various soils. Ripens before Concord. Deteriorates rapidly in quality after ripening. Blooms rather late.

CAMPBELL EARLY (Black)-Bunch and berry are large; high quality when mature, but colors before ripe and often marketed in unripe condition; good keeper and shipper. Vine is productive, hardy but not adapted to wide range of soils. Ripens about two weeks before Concord. Blooms midseason.

CONCORD (Black) - The most widely-planted grape. Superior in hardiness, productivity, and regularity in bearing and in ability to withstand disease and in sects. Good size of bunch and berry. Very handsome in appearance. The fruit is sprightly and refreshing. It is the leader for making grape juice. No other grape has been able to compete with it on the market, as it can be produced so cheaply. Blooms midseason.

DELAWARE (Red)-The standard of quality; the best table grape. Unusually hardy; adapted to wide variation of soils and conditions, and usually bears abundantly. Ripens a few days earlier than Concord. Ships and keeps well and more immune to black rot than other commercial varieties. Its faults are: Small size of vine and berry, slow grower, and foliage susceptible to mildew, which can be controlled by spraying with Bordeaux mixture. It succeeds best in deep, rich, well-drained. warm soils, and should be planted more closely than most other varieties. It commands the highest prices. and is valuable North and South for both home use and market. Blooms rather late.

DIAMOND (Green)-Seldom surpassed in quality and beauty. It is the hardiest. most productive and vigorous of the green grapes, although Niagara bears more heavily in most localities. A good keeper and shipper. It deserves a high place among the best for commercial and home vineyards; unfortunately often sold as Niagara. Medium size; green, with tinge of yellow, but less yellow than Niagara. Can be grown as widely as Concord. Blooms midseason.
MOORE'S EARLY (Purplish-Black) - The most widely planted early commercial grape. Ripens two weeks earlier than Concord. Fair to good in quality. It is best described as an early Concord. It should be planted on rich, well-drained, loose soil, but succeeds on rocky, hilly ground, where others fail. Blooms midseason.

NIAGARA (Green)-The most widely planted green grape Larger bunches and berries than Concord, as good, or better in quality, but inferior to Diamond. Productive, vigorous, adaptable; not as hardy as Concord. Ripens about with Concord. Keeps fairly well. Flavor not at its best unless fully ripe. Blossoms midseason.

WORDEN (Black)-Much better quality, larger berries and bunches and handsomer than Concord and is equally healthy, hardy, vigorous, and productive, but often more particular as to soil. Its chief fault is a tendency to crack. Ripens a week to ten days earlier. It does not keep long, but is especially desirable for the home garden and for nearby markets.

"I had about 25 tons of grapes from your vines I set out fonr years aro. They are pronounced the liest flavor of any wrapes in this valley."- w. Wetherell, San Juan County, New Mexieo. REST IBY COMPARISON

"Hest stoek $(500$;rape vines, 2 peach. 2 aprieot) for the priee we ever bought and have bounht from several museries."otto Flowers, Washingtoll County, Oklalioma.

\section{Proper Care Brings Great Rewards}

These Coneord and Niazara grape vines hore fruit the seeond season. They were planted hy onr customer. Mr. Wm. Meyers of Irookfield, Mo., in the spring and the pieture was taken in Oetoher of the next year.

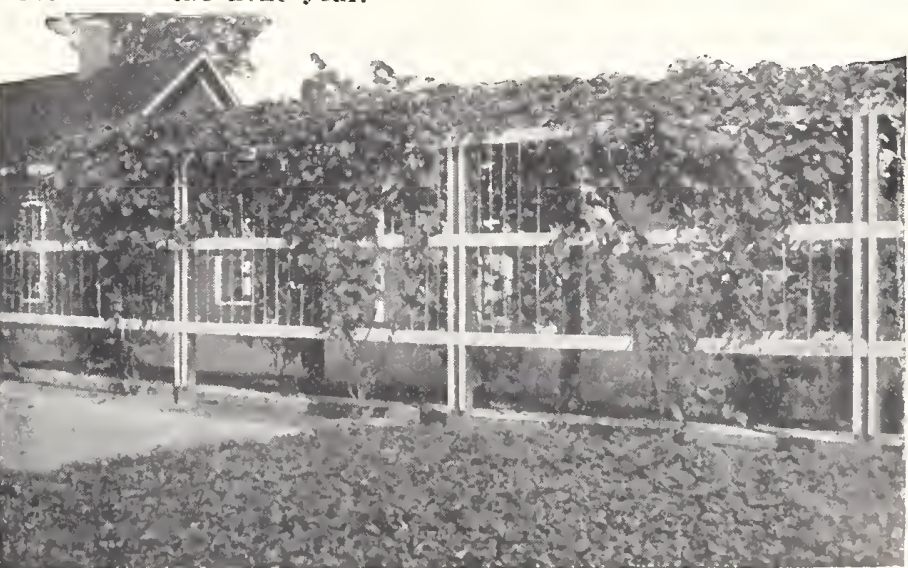




\section{Plums-A Source of Delight in the Yard}

DLUMS are especially fine for eating fresh, for jellies, preserves and marmalade, and unexcelled for canning and drying. Some varieties will thrive wherever apples or peaches can be grown. Most of them bear the third or fourth year. One of the best fruit trees for the home garden.

ABUNDANCE (Early)-A pinkish-red Japanese plum, covered with a thin bloom. Medium size, roundish oval. Flesh is yellow, tender, melting, unusually juicy and refreshing; sweet, aromatic; quality good to very good. Tree is a vigorous grower, large, hardy and very productive. Adaptable to wide diversity of soils and climates, bears heavily and regularly. Should be picked before quite ripe; dropping and rot are thus avoided and flavor is better. Blooms early.

BRADSHAW-Medium to large; dark purplish red with yellowish dots and blue bloom. Flesh greenish-yellow. Good quality. Flavor rich, sweet. Midseason. Tree a good grower. Blooms very late.

BURBANK (Midseason)-A dark red, roundish Japanese plum; better quality and shipper and less susceptible to brown rot than Abundance. The flesh is a deep yellow, firm, very juicy, aromatic, and sweet; quality good to very good. The tree is healthy, not quite as fast a grower as Abundance; flat, spreading top. A week later than Abundance. Blooms very early.

FRENCH DAMSON (Late)-Largest and best quality of the Damsons. Dull purplish-black color. Flesh very juicy, tender, sweet, pleasant, and good quality. Tree large, vigorous, spreading, hardy and productive. Ripens a little later than Shropshire. Blooms midseason.

REINE CLAUDE (Green Gage-Midseason)-A large, roundish, oval plum; light greenish-yellow. Firm, sweet, mild, rich flavor, very juicy, aromatic; good to very good in quality. Tree is of medium size and vigor, productive, and hardy. Thrives best on light, sandy soils. Chief defects: Susceptible to sunscald and fruit cracks if showers occur at ripening time. Blooms midseason. Should be in every home garden.

RED JUNE (Early)-A large garnet-red, heart-shaped Japanese plum, pointed at tip. Flesh is light yellow, meaty, sweet, peculiarly aromatic; quality fair to good. Tree is a large, vigorous, upright, spreading grower; very hardy and productive. Should be planted with other varieties for the purpose of cross-pollination. Abundance and Burbank are good pollenizers for this variety. Usually ripens a week before Abundance. Blooms early.

SHROPSHIRE DAMSON (Late)-The most widely planted Damson. Oval shape; purplish-black covered with a thick bloom; flesh is juicy, firm, tender, sprightly and pleasant. Tree is strong, vigorous grower, quite hardy. A standard for productivity and reliability in bearing; fair for eating when fully ripe or after a light frost; one of the best for culinary purposes. Fruit ripens late over a long season. Blooms late.

\section{Endicott Plums}

\section{(Mammoth Gold)} Enjoy some of this
fine fruit from your own yard or orehard.

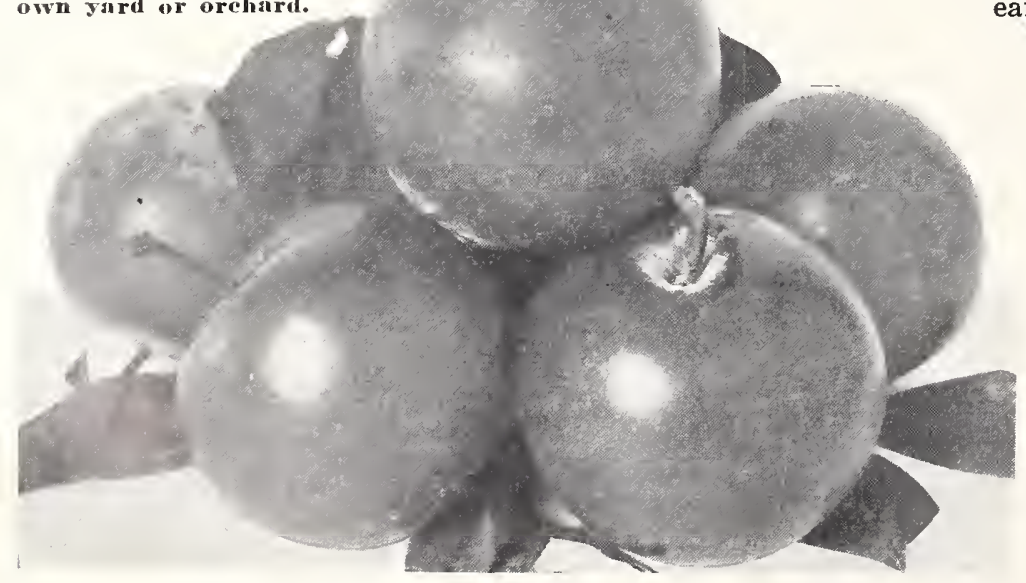

AMERICA (Midseason)-An improved Gold, originated by Burbank; a beautiful waxen yellow, with currantred cheek. Flesh is yellow, juicy, sweet, very good for cooking. The tree is a large. strong grower, spreading, o p e $n$ t o p ; extremely hardy and productive, and succeeds where others fail. Considering its parentage, phenomenally free from rot. Midseason bloomer.

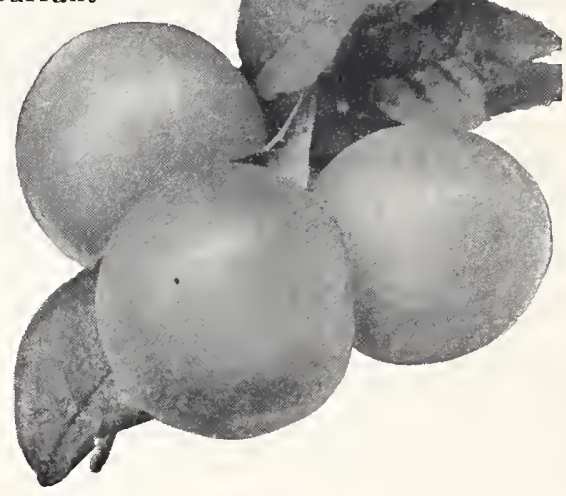

ITALIAN PRUNE (Late)-The Italian, or Fellenburg, is the largest, best and one of the most widely grown of all prunes. Long, oval shape, rich, purplish-black; almost dark wine color, overspread with a thick blue bloom. It is a very large size, flesh firm, yellow, aromatic, juicy, rich, sweet and very good to best quality. Fine flavor for dessert and cooking. Keeps and ships well. Succeeds everywhere except in the more Southern states. Late bloomer.

LOMBARD (Midseason)-The most widely planted plum in America, noted for hardiness and dependability; adaptable to widely different soils and climates, unusually healthy, very productive, regular bearer and fruit is comparatively free from attacks of the curculio. Medium to large size and oval shape; purplish-red or reddishviolet color, overspread with a thin bloom; easily sold because of its beauty. It is inferior in quality, but does very well for cooking, canning and preserving. Blooms midseason.

OMAHA (Early)-A large, round, brilliant, coral-red plum. Flesh is firm, yellow, juicy and sweet. Tree is a strong, vigorous grower, hardy and productive.

WILD GOOSE (Very Early)-An old-time favorite; bright red; medium size; flesh is yellow, very juicy, tender, melting, very sweet except slightly acid next to the seed; quality fair to good. This is a very large, strong, flattopped grower; hardy. Good shipper and keeper; comparatively free from brown rot and curculio. The Wild Goose is a native plum and should be planted near other plums of this class for pollenization. Blooms medium early.

ENDICOTT (Midseason)-Endicott combines the high quality of the European with the hardiness and adaptability of the Japanese. One of the sweetest, juiciest plums. It averages very large in size, roundish, slightly flattened at the end; dark garnet-red, with a faint bloom. Flesh is a light yellow, firm and rich. Mr. Endicott, the originator, of Southern Illinois, wrote of this plum:

"I have fruited it side by side with Red June and Gold, and I think it is worth more than both of them put together. In fact, it is the best plum I have ever seen for our low elevation and changeable climate. It generally ripens here about the Fourth of July. By thinning and spraying them with self-boiled lime-sulphur, I have grown them two inches in diameter." 


\section{Plums Are Easy to Grow and Bear Young}

SATSUMA-Large, dark brilliant red. Flesh dark red, good quality. Flavor rather acid. Ripens medium to medium late. Sterile. Not as hardy as Bradshaw. Tree, spreading. Blooms early.

WICKSON-Large to very large, dark red. Flesh yellow, quality good. Flavor sweet. Season medium. Tree upright grower. Blooms early.

\section{Hansen's Hybrid Plums}

RIGINATED by Prof. Hansen of the South Dakota Agricultural College. They are exceptionally hardy and also withstand extremely hot, dry weather, bear very young and heavily and are the first plums to ripen. Good for dessert and cooking.

HANSKA-Good size, about $1 \frac{1 / 2}{2}$ in. in diameter, bright red. Flesh reddish; flavor delicious. Very good quality: Tree strong, upright, vigorous.

OPATA-Size 1 in. or more in diameter, dark red. High quality. Bears second year. Tree often grown in bush form.

SAPA-Dark glossy purple. Flesh purple-red. Fine flavor. Bears early and heavily. Tree is spreading and handsome in appearance.

WANET A-Very large, 2 in. in diameter. Delicious quality. Regarded as the best of the Hansen hybrids.

\section{Compass Cherry-Plum}

COMPASS CHERRY-PLUM-Very hardy, bears young, often second year. Fruit is nearly inch in diameter, bright red; sweet, juicy and fine flavor.

\section{Quince Adds Flavor}

THE Quince is the ideal fruit for flavoring preserves, I jellies, marmalade and cooked fruit. Trees thrive on well-drained, fairly rich soil, are long-lived, and, being small, dwarfish growers, can be planted closely. They are especially suited for yards and gardens.

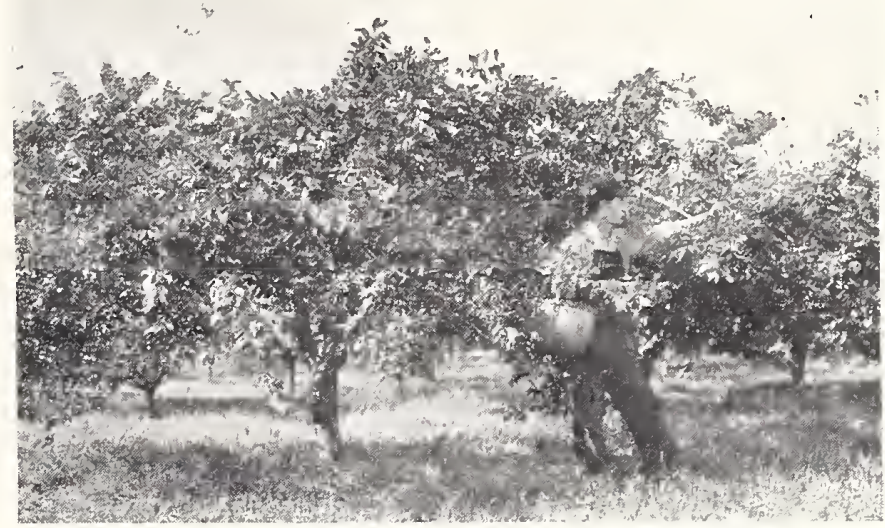

Burbank Plums Grown frou Neosho Trees

\section{Luscious Apricots}

T HE Apricot is one of the most delightfully luscious fruits 1 grown, when eaten fully ripe and fresh from the tree. It is remarkable that such a rich and beautiful, golden, sweet fruit is not planted more, especially since it ripens just after the early cherries and before the best early peaches. Apricots succeed in many localities and will stand more winter cold than peaches, although the bloom is more apt to be injured by spring frosts. The soil should be well drained, the subsoil as well as the surface. A northern or western slope is best so the opening of the buds will be retarded and the danger of frost damage lessened.

SUPERB (Freestone) - The best apricot for Eastern planting; medium size; roundish oval; smooth, light salmon color, with numerous red dots; flesh is yellow, firm, subacid; very good. The tree is a very hardy Russian type, a vigorous grower; very productive; latest-blooming apricot; is adapted to peach regions.

\begin{tabular}{|c|c|c|c|c|c|c|}
\hline VARIETIES & RIPENS & BLOOM & QUALITY & SIZE & HARDINESS & COLOR \\
\hline 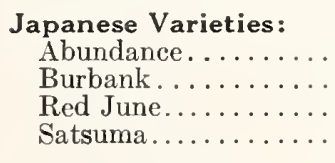 & $\begin{array}{l}\text { Early } \\
\text { Early } \\
\text { Early } \\
\text { Medium }\end{array}$ & $\begin{array}{l}\text { Early } \\
\text { Early } \\
\text { Early } \\
\text { Early }\end{array}$ & $\begin{array}{l}\text { Good } \\
\text { Very Good } \\
\text { Fair } \\
\text { Good }\end{array}$ & $\begin{array}{l}\text { Medium } \\
\text { Medium } \\
\text { Medium } \\
\text { Large }\end{array}$ & $\begin{array}{l}\text { Hardy } \\
\text { Hardy } \\
\text { Hardy } \\
\text { Half-hardy }\end{array}$ & $\begin{array}{l}\text { Bright Red } \\
\text { Dark Red } \\
\text { Dark Red } \\
\text { Dark Red }\end{array}$ \\
\hline $\begin{array}{l}\text { Native Varieties: } \\
\text { Omaha.................. } \\
\text { Wild Goose...... }\end{array}$ & $\begin{array}{l}\text { Early } \\
\text { Very Early }\end{array}$ & Medium & $\begin{array}{l}\text { Good } \\
\text { Fair }\end{array}$ & $\begin{array}{l}\text { Large } \\
\text { Medium }\end{array}$ & $\begin{array}{l}\text { Very Hardy } \\
\text { Hardy }\end{array}$ & $\begin{array}{l}\text { Light Red } \\
\text { Bright Red }\end{array}$ \\
\hline 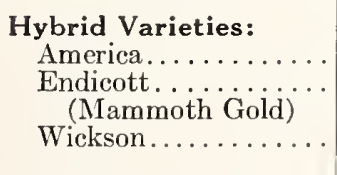 & $\begin{array}{l}\text { Medium } \\
\text { Early } \\
\text { Medium }\end{array}$ & $\begin{array}{l}\text { Medium } \\
\text { Medium }\end{array}$ & $\begin{array}{l}\text { Medium } \\
\text { Good } \\
\text { Good }\end{array}$ & $\begin{array}{l}\text { Medium } \\
\text { Large } \\
\text { Very Large }\end{array}$ & $\begin{array}{l}\text { Half-hardy } \\
\text { Hardy } \\
\text { Half-hardy }\end{array}$ & $\begin{array}{l}\text { Golden Yellow } \\
\text { Dark Red } \\
\text { Dark Red }\end{array}$ \\
\hline $\begin{array}{l}\text { Domestica Varieties: } \\
\text { Bradshaw .......... } \\
\text { Green Gage........ } \\
\text { (Reine Claude) } \\
\text { Italian Prune....... } \\
\text { Lombard.......... }\end{array}$ & $\begin{array}{l}\text { Medium } \\
\text { Medium } \\
\text { Late } \\
\text { Medium }\end{array}$ & $\begin{array}{l}\text { Medium } \\
\text { Medium } \\
\text { Late } \\
\text { Medium }\end{array}$ & $\begin{array}{l}\text { Good } \\
\text { Best } \\
\text { Good } \\
\text { Fair }\end{array}$ & $\begin{array}{l}\text { Medium } \\
\text { Medium } \\
\text { Large } \\
\text { Medium }\end{array}$ & $\begin{array}{l}\text { Hardy } \\
\text { Hardy } \\
\text { Hardy } \\
\text { Very Hardy }\end{array}$ & $\begin{array}{l}\text { Purplish-Red } \\
\text { Yellow } \\
\text { Dark Blue } \\
\text { Purplish-Red }\end{array}$ \\
\hline $\begin{array}{l}\text { Damson Varieties: } \\
\text { French } \ldots \ldots \ldots \ldots \ldots \\
\text { Shropshire........ }\end{array}$ & $\begin{array}{l}\text { Late } \\
\text { Late }\end{array}$ & $\begin{array}{l}\text { Medium } \\
\text { Late }\end{array}$ & $\begin{array}{l}\text { Good } \\
\text { Fair }\end{array}$ & $\begin{array}{l}\text { Small } \\
\text { Small }\end{array}$ & $\begin{array}{l}\text { Very Hardy } \\
\text { Very Hardy }\end{array}$ & $\begin{array}{l}\text { Dark Blue } \\
\text { Dark Blue }\end{array}$ \\
\hline 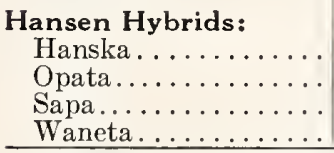 & $\begin{array}{l}\text { Very Early } \\
\text { Very Early } \\
\text { Very Early } \\
\text { Very Early }\end{array}$ & $\begin{array}{l}\text { Medium } \\
\text { Medium } \\
\text { Medium } \\
\text { Medium } \\
\end{array}$ & $\begin{array}{l}\text { Very Good } \\
\text { Good } \\
\text { Good } \\
\text { Very Good }\end{array}$ & $\begin{array}{l}\text { Large } \\
\text { Large } \\
\text { Medium } \\
\text { Very Large } \\
\end{array}$ & $\begin{array}{l}\text { Very Hardy } \\
\text { Very Hardy } \\
\text { Very Hardy } \\
\text { Very Hardy }\end{array}$ & $\begin{array}{l}\text { Bright Red } \\
\text { Dark Red } \\
\text { Dark Purple } \\
\text { Red }\end{array}$ \\
\hline
\end{tabular}

The Italian Prune is a freestone. The others are cling or semi-clings. 


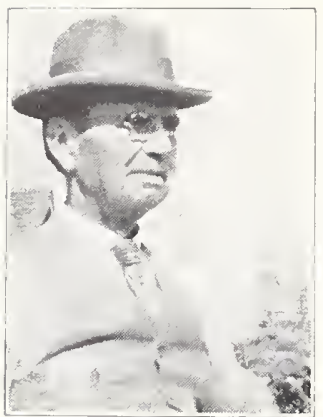

A California customer sent us this picture. He is
proud of his J. H. Hale

\section{APPLE ORCHARDS---Opportunities for Thinkers}

One man succeeds where another-with equally good opportunities-fails-management is the main factor.

There is a fine young orchard near Neosho of our trees, while across the road there is nothing left of an orchard planted at the same time. That was due to poor trees at the start.

Compare the average annual cash returns per acre over 5 years of these two Michigan orchards:

$\begin{array}{cccc} & \text { Trees } 13 \text { to } 20 \text { yrs. old } & 21 \text { to } 35 \text { yrs. old } & \text { Over } 35 \text { yrs. old } \\ \text { A. } & \$ 111.50 & \$ 151.25 & \$ 334.50 \\ \text { B. } & 21.30 & \ldots \ldots . & 48.00\end{array}$
These orchards are a short distance apart, contain the same varieties and the trees are about the same average age. The difference in results lies in management and location.

\section{Here Are The Factors That Govern Profits}

(1) A Good Site-That is a location which is not subject to severe spring frosts-ground that is higher than the adjacent land and has good air drainage. That means regularity of production. We can show you orchards in valleys and in pockets which never have any fruit, or so little as to amount to nothing.

(2) A Good Soil-This calls for fertility and depth. It means heavy yields and lower cost of production.

(3) Next in importance is production of a high percentage of Grade A fruit which commands the best price. That means size and freedom from blemishes. Size is determined by soil and good management. Blemishes are prevented by timely and thorough spraying and by careful handling.

(4) Selection of Varieties-

(A) Heavy yields are the first consideration. Shy bearers increase the cost of production.

(B) Select varieties that bear a large percentage of grade A fruit.

Part of Apple Display, Neosho Harvest Show. Nearly All the Exhibitors Are Our Patrons

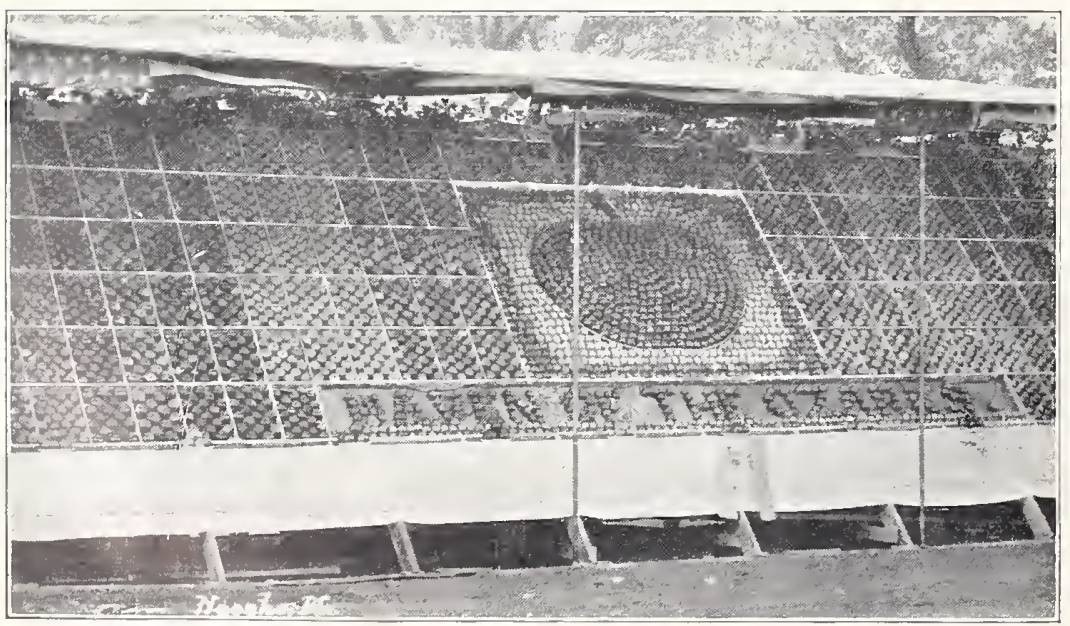

(C) Next in importance is the selection of varieties that command the best prices. The wholesaler and retailer will pay good prices for what he can readily sell. Usually quality varieties are preferred, but there are exceptions-early varieties like Yellow Transparent and Duchess which are used for cooking. Ben Davis, Black Ben, Champion and Gano have proved quite profitable for many growers, but such varieties do not stimulate the demand for apples and there are some better varieties which are usually more profitable in most districts.

(D) It should not be necessary to point out that varieties must be adapted to one's climate-for instance northern varieties like R. I. Greening have not proved successful in the Ozarks of Missouri. It is certainly a big gamble to plant (except in a small way for testing) varieties whose production and behavior in one's own district are unknown. An orchardist south of Neosho lost 25 three-year-old trees of an untried variety from winter injury, while none of his other varieties were damaged.

(E) There is no perfect variety. All have some drawback such as susceptibility to blight, etc. The Grimes Golden is adapted to a wide range of climate, stands high in production and regularity of bearing, bears a good per cent of grade $A$ fruit and brings good prices on most markets. But it has one bad fault-susceptibility to collar-rot which attacks the trunk near the ground. This trouble can be prevented by planting double-worked trees. (See page 25.)

(F) If you plan to ship to market, about four varieties is enough. For local market it is well to have some early and midseason varieties so as to supply the demand over a long season.

(G) If your varieties are ready to sell when there is the least competition from other fruits or from other growers, your sales will be easier and your prices higher. Neosho is in the heart of a big producing center of Strawberries, practically all Aroma, which ripens at a time when competition from other districts is least.

(5) Next comes the problem of arrangement. Some varieties are more or less sterile so it is wise to plant not more than four rows of one variety alternately with another for crosspollination. The set of fruit will be greatly improved by moving bees into the orchard, about one colony to the acre, avoiding the hazard of poisoning by putting the bees in the orchard between the pink spray and the calyx spray.

(6) Securing Nursery Stock-Since an orchard is a life time investment and the purchase price will be an insignificant item of cost by the time the trees come into profitable bearing, obviously it pays to plant only the best trees-trees that will thrive and produce profitable crops for many years.

(7) Proper Care includes planting, maintenance of soil fertility and moisture, timely and thorough spraying, pruning, etc.

(8) Information-See index page 3 for other data and other fruits. Tell us your problems. We will help you, to solve them to the best of our ability. 


\section{Growers in Every State Endorse Neosho Stock Wherever the "Variety" Succeeds Neosho Trees Thrive}

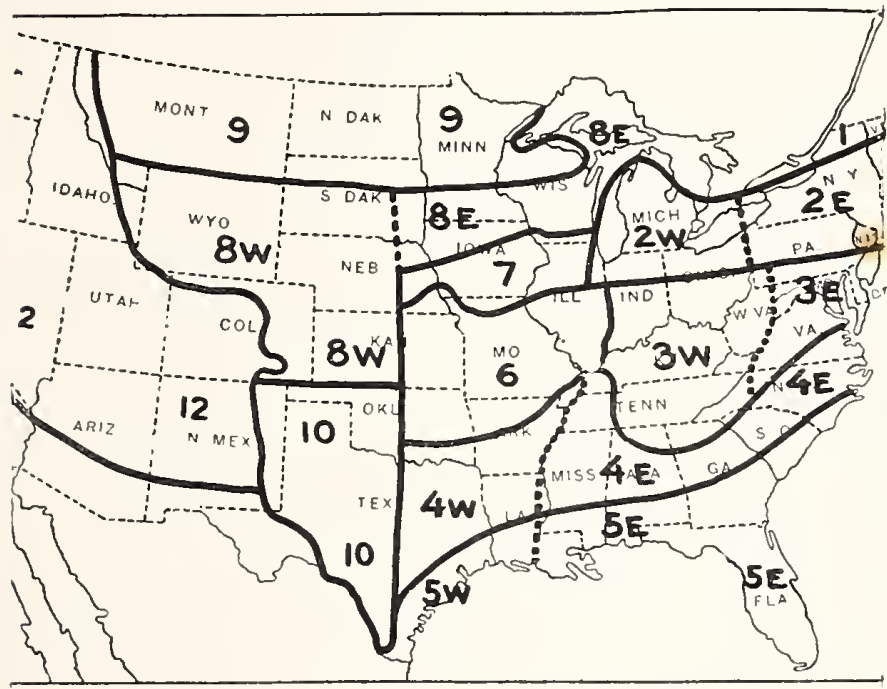

\section{Select Varieties Carefully}

This map shows the fruit districts of the United States. In the tables one star indicates that the variety is known to succeed, two stars indicate the most dependable.

It is advisable to consult with any of your neighbors who may have had experience in fruit-growing in your locality. Your State Experiment Station will also be glad to give you the benefit of their investigations.

The varieties are listed in their approximate order of ripening.

\begin{tabular}{|c|c|c|c|c|c|c|c|c|c|}
\hline & & & & Dist & ct $\mathbf{N}$ & $\mathbf{m}$ & & & \\
\hline APPLE & 2 & 3 & $4 \mathrm{E}$ & $4 \mathrm{~W}$ & 6 & 7 & 8 & 10 & 11 \\
\hline Liveland Raspb & $* *$ & $* *$ & & 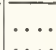 & $* *$ & $\stackrel{*}{*}$ & $* *$ & & \\
\hline thr & $* *$ & $* *$ & ${ }^{* *}$ & $\because *$ & ${ }^{* *}$ & $* *$ & $\begin{array}{l}* * \\
\ldots .\end{array}$ & a* & $* *$ \\
\hline & $\sigma_{*}$ & $* *$ & $* *$ & $* *$ & $* *$ & * & $\because "$ & $\cdots$ & \\
\hline ess of & ** & ** & * & $* *$ & *** & $*$ & ${ }^{* *}$ & ${ }^{*}$ & * \\
\hline Early Harv & & & $*$ & * & $*$ & & & & \\
\hline B & $\because$ & $\because *$ & - & * & $* *$ & $* *$ & $\because$ & $\because *$ & $\because *$ \\
\hline d. & $\because *$ & ** & $\because 4$ & $\%^{\circ}$ & $* *$ & $* *$ & $\because 0^{\circ}$ & $\because *$ & ** \\
\hline g David. & $*$ & ${ }^{* *}$ & ${ }^{* *}$ & & $\stackrel{* *}{*}$ & $* *$ & ** & $* *$ & ** \\
\hline $\mathrm{osh}$. & ** & * & & $\cdots$ & $*$ & & $\because$ & & \\
\hline Golden. & * & ** & $\because$ & $\because$ & ** & $* *$ & $*$ & $*$ & $\because *$ \\
\hline & * & & & & & & & & . \\
\hline & * & ${ }^{*} *{ }^{\circ}$ & $*$ & $\because$ & $\because$ & $\because$ & $\because$ & $\because$ & \\
\hline & * & *** & * & - & * & $* *$ & ** & - & $* *$ \\
\hline W & * & $* *$ & * & $\because$ & $* *$ & $\stackrel{*}{*}$ & $\because$ & $\because$ & $\because$ \\
\hline & * & $* *$ & * & : & $* *$ & $* *$ & : & 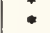 & : \\
\hline & * & $\cdots$ & & & $\cdots$ & $\ldots$ & 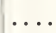 & $\cdots$ & 0 \\
\hline & $\because$ & * & $\because$ & $\because$ & $* *$ & $* *$ & $\because$ & $\because *$ & $\sigma_{* *} \cdot$ \\
\hline $\begin{array}{l}\text { Wi } \\
\text { Spi }\end{array}$ & * & ${ }^{*}$ & $*$ & ${ }^{*}$ & *** & $* *$ & $*$ & & $F^{*}$ \\
\hline Ror & * & $* *$ & *i* & $\because$ & $\because *{ }^{\circ}$ & ${ }^{*} *{ }^{\circ}$ & $\because$ & $\cdots$ & $\begin{array}{l}\cdots \\
\cdots\end{array}$ \\
\hline & * & $* *$ & ** & * & *** & ** & $\cdots$ & $1 \times$ & ${ }^{\circ}-0^{\circ}$ \\
\hline & * & ** & *** & $*$ & $* *$ & & & $\cdots$ & $* *$ \\
\hline Nor & * & $\because \ddot{*}$ & $\dot{* * i}$ & $\because{ }^{*}$ & $* *$ & $* *$ & $\because$ & $\because$ & $7 *$ \\
\hline & & ** & $* *$ & $* *$ & *** & ** & * & $*$ & ** \\
\hline & ** & & & & & & & & \\
\hline Yellow Newtown. & & $\cdots \cdot$ & $\because$ & .... & $\ldots$ & .... & $\ldots$ & $\ldots$ & .... \\
\hline CRABAPPLE & 2 & 3 & $4 \mathrm{E}$ & $4 \mathrm{~W}$ & 6 & 7 & 8 & 10 & 11 \\
\hline Florenc & * & $*$ & * & * & * & $*$ & * & & \\
\hline & & * & * & & * & * & * & & $\ldots$ \\
\hline Hyslop. & $*$ & $*$ & & * & & & * & $\cdots$ & $\therefore$ \\
\hline QUINCE & $*$ & $*$ & $\ldots$ & $\ldots$ & * & $*$ & $\ldots$ & $\cdots$ & $\cdots$ \\
\hline PEAR & 2 & 3 & $4 \mathrm{E}$ & $4 \mathrm{~W}$ & 6 & 7 & 8 & 10 & 11 \\
\hline Flemish Beauty.. & * & * & * & $\ldots$ & *** & $* *$ & $*$ & & \\
\hline & $*$ & $\ddot{*}$ & * & $\because$ & $* *$ & $*$ & $\because$ & $*$ & $\%$ \\
\hline & & & & & & & & 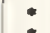 & \\
\hline & & ** & & & & & & - & \\
\hline & *** & ** & $*$ & & te & 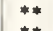 & * & - & 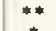 \\
\hline & * & *** & * & ** & *** & ** & $\because$ & $\because$ & * \\
\hline & . & 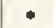 & & & & & & & \\
\hline
\end{tabular}

\begin{tabular}{|c|c|c|c|c|c|c|c|c|c|}
\hline PEACH & 2 & 3 & $4 \mathrm{E}$ & $4 \mathrm{~W}$ & 6 & 7 & 8 & 10 & 11 \\
\hline 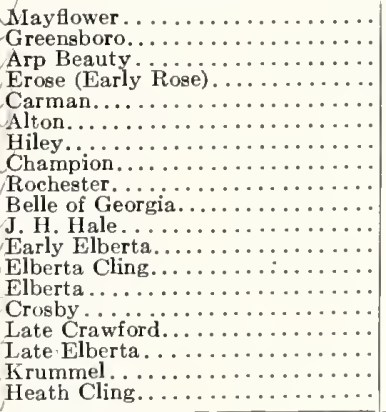 & $\begin{array}{c}* * \\
\cdots \\
* * \\
* \\
\ldots \\
* \\
* \\
\cdots \\
* \\
* \\
* \\
* \\
* \\
* \\
*\end{array}$ & $\begin{array}{c}* \\
* * \\
* \\
* \\
* \\
* * \\
* * \\
* \\
* \\
* \\
* \\
* \\
* \\
* \\
* \\
*\end{array}$ & $\begin{array}{c}* \\
* * \\
* * \\
* * \\
* * \\
* \\
* * \\
\cdots \\
\cdots \\
\cdots \\
* \\
* \\
* \\
\cdots \\
* \\
* \\
\cdots \\
\cdots \\
*\end{array}$ & $\begin{array}{l}\cdots \\
\cdots \\
\cdots \cdots \\
\cdots \cdots \\
\cdots \cdots \\
\cdots \cdots \\
\cdots \cdots \\
\cdots \\
\cdots \\
\cdots \\
\cdots * \\
\cdots\end{array}$ & $\begin{array}{l}* \\
* * \\
* * \\
* * \\
* * \\
* * \\
* * \\
* * \\
* * \\
* * \\
* * \\
* * \\
* \\
* \\
* * \\
* * \\
* \\
* *\end{array}$ & $\begin{array}{l}* * \\
* * \\
* * \\
* * \\
* * \\
* * \\
* * \\
* \\
* * \\
* * \\
* * \\
* \\
* \\
* \\
* * \\
* * \\
* \\
* \\
* \\
*\end{array}$ & $\begin{array}{l}\cdots \\
\cdots \\
\cdots \\
\cdots \\
\cdots \\
\cdots \\
\cdots \\
\cdots \\
* \\
* \\
* \\
* \\
* \\
*\end{array}$ & $\begin{array}{c}* \\
* \\
* * \\
* \\
* * \\
\cdots \\
\because \cdots \\
* \\
* \\
* \\
* * \\
* * \\
* \\
\cdots \\
* \\
* \\
* * \\
\end{array}$ & $\begin{array}{c}* \\
* * \\
* \\
* * \\
* \\
\cdots \\
* \\
* * \\
* * \\
* * \\
* * \\
* * \\
* * \\
* * \\
* * \\
* \\
* \\
*\end{array}$ \\
\hline PLUM & 2 & 3 & $4 \mathrm{E}$ & $4 \mathrm{~W}$ & 6 & 7 & 8 & 10 & 11 \\
\hline 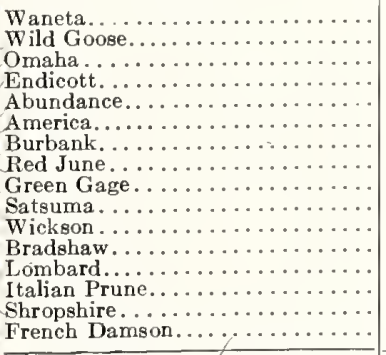 & $\begin{array}{l}* \\
* \\
* \\
* * \\
* \\
* * \\
* * \\
* \\
* \\
* \\
* \\
* \\
* \\
*\end{array}$ & $\begin{array}{c}* \\
* \\
* \\
* \\
* * \\
* \\
* * \\
* \\
* \\
\cdots \\
\cdots \\
* \\
* \\
* \\
* \\
* \\
\end{array}$ & $\begin{array}{c}\cdots \\
\cdots \\
\cdots \\
\cdots * \\
* * \\
* * \\
* * \\
* \\
* \\
\cdots \\
\cdots \\
\cdots \\
\cdots \\
* \\
* \\
* \\
*\end{array}$ & {$\left[\begin{array}{c}* \\
\cdots \\
\cdots \\
\cdots * \\
* \\
* \\
* \\
\cdots \\
\cdots \\
\cdots \\
\cdots \\
\cdots \\
\cdots \\
\cdots \\
\cdots\end{array}\right.$} & \begin{tabular}{c}
$*$ \\
$*$ \\
$* *$ \\
$* *$ \\
$* *$ \\
$* *$ \\
$* *$ \\
$*$ \\
$*$ \\
$\cdots$ \\
$\cdots$ \\
\hdashline \\
\hdashline$*$ \\
$* *$ \\
$* *$ \\
$* *$ \\
\end{tabular} & \begin{tabular}{|c|}
$*$ \\
$*$ \\
$* *$ \\
$* *$ \\
$* *$ \\
$* *$ \\
$* *$ \\
$*$ \\
$\cdots$ \\
$\cdots$ \\
\hdashline$\cdots$ \\
\hdashline$\cdots$ \\
$* *$ \\
$* *$ \\
$* *$ \\
$* *$ \\
\end{tabular} & 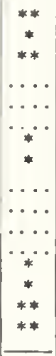 & {$\left[\begin{array}{c}\cdots \\
\cdots \\
\cdots \\
\cdots \\
\cdots \\
* \\
* \\
\cdots \\
\cdots \\
\cdots \\
\cdots \\
\cdots \\
\cdots \\
\cdots \\
\cdots \\
\cdots \\
\end{array}\right.$} & 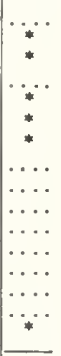 \\
\hline APRICOT, Superb & $*$ & * & * & * & * & * & $\cdots$ & $*$ & $\ldots$ \\
\hline CHERRY & 2 & 3 & $4 \mathrm{E}$ & $4 \mathrm{~W}$ & 6 & 7 & 8 & 10 & 11 \\
\hline $\begin{array}{l}\text { Montmorency } \\
\text { English Morello } \\
\text { Napoleon (Swee } \\
\text { Bing. ........ } \\
\text { Gov. Wood.... } \\
\text { Windsor...... }\end{array}$ & $\begin{array}{c}* \\
* * \\
* * \\
* * \\
* \\
* \\
* \\
* \\
\end{array}$ & $\begin{array}{c}* \\
* \\
* * \\
* * \\
* \\
\cdots \\
\cdots \\
\cdots \\
\end{array}$ & $\begin{array}{c}* \\
* \\
* \\
\cdots \cdots \\
\cdots \cdots \\
\cdots \cdots \\
\end{array}$ & $\mid \begin{array}{c}\cdots \\
\cdots \\
\cdots \\
\cdots \\
\cdots \\
\cdots \\
\cdots \\
\end{array}$ & $\begin{array}{c}* \\
* * \\
* * \\
* * \\
* \\
\cdots \cdots \\
\cdots \cdots \\
\cdots \\
\end{array}$ & \begin{tabular}{|c|}
$*$ \\
$* *$ \\
$* *$ \\
$*$ \\
$*$ \\
$\cdots \cdots$ \\
$\cdots \cdots$ \\
$\cdots \cdots$ \\
\end{tabular} & {$\left[\begin{array}{c}* * \\
* * \\
* \\
* \\
\cdots \\
\cdots \\
\cdots \\
\end{array}\right.$} & {$\left[\begin{array}{c}* * \\
* * \\
\cdots \\
\cdots \cdots \\
\cdots \cdots \\
\cdots \cdots \\
\cdots \cdots \\
\end{array}\right.$} & {$\left[\begin{array}{l}\cdots * \\
* * \\
\cdots \cdots \\
\cdots \cdots \\
\cdots \cdots \\
\cdots \cdots \\
\cdots \cdots \\
\end{array}\right.$} \\
\hline GOOSEBERRY & 2 & 3 & $4 \mathrm{E}$ & $4 \mathrm{~W}$ & 6 & 7 & 8 & 10 & 11 \\
\hline Jregon Champ & * & * & $\cdots$ & $\cdots$ & * & * & * & * & * \\
\hline CURI & 2 & 3 & $4 \mathrm{E}$ & $4 \mathrm{~W}$ & 6 & 7 & 8 & 10 & 11 \\
\hline & $\begin{array}{l}* \\
* * \\
*\end{array}$ & $\begin{array}{c}* * * \\
* \\
*\end{array}$ & & & $\begin{array}{c}* \\
* * \\
* \\
\end{array}$ & $\begin{array}{l}* \\
* * \\
*\end{array}$ & * & * & ${ }^{\cdots} *$ \\
\hline GRAPE & 2 & 3 & $4 \mathrm{E}$ & $4 \mathrm{~W}$ & 6 & 7 & 8 & 10 & 11 \\
\hline 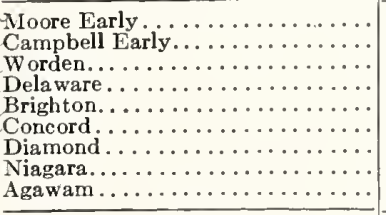 & $\begin{array}{l} \\
* \\
* * \\
* * \\
* \\
* * \\
* * \\
* *\end{array}$ & $\begin{array}{c}* * \\
* \\
* * \\
* * \\
* \\
* * \\
* \\
* * \\
\\
\end{array}$ & $\begin{array}{c}* * \\
* \\
* \\
* \\
* \\
* * \\
* * \\
* * \\
* \\
\end{array}$ & $\begin{array}{c}* \\
* \\
* \\
* \\
* \\
* \\
\cdots \\
\cdots\end{array}$ & $\begin{array}{c}* * \\
* \\
* * \\
* \\
* \\
* * \\
* * \\
* * \\
* \\
\end{array}$ & $\begin{array}{c}* * \\
* \\
* * \\
* \\
* \\
* * \\
* * \\
* * \\
* *\end{array}$ & $\begin{array}{l}* \\
* \\
* \\
* \\
* \\
* \\
* \\
*\end{array}$ & $\begin{array}{l}\cdots \cdots \\
\cdots \\
\cdots \\
\cdots \\
\cdots \\
\cdots \\
\cdots \\
\end{array}$ & $\begin{array}{l}\cdots \cdot \\
\cdots \cdots \\
\cdots \cdots \\
\cdots \cdots \\
\cdots \cdots \\
\cdots \cdots \\
\cdots \\
\end{array}$ \\
\hline BLACKB & 2 & 3 & $4 \mathrm{E}$ & $4 \mathrm{~W}$ & 6 & 7 & 8 & 10 & 11 \\
\hline & $\because$ & * & $\begin{array}{c}* * \\
* \\
\cdots \\
\end{array}$ & $\begin{array}{c}* * \\
* \\
\cdots \\
\cdots\end{array}$ & $*$ & $\begin{array}{l}\cdots \\
\cdots \\
\end{array}$ & $\cdots$ & $\begin{array}{c}* \\
* \\
\cdots \\
\end{array}$ & $*$ \\
\hline DEWBERRY, Lucretia & + & * & * & * & $*$ & $\ldots$. & $\cdots$ & $*$ & $*$ \\
\hline RASPBERRY & 2 & 3 & $4 \mathrm{E}$ & $4 \mathrm{~W}$ & 6 & 7 & 8 & 10 & 11 \\
\hline & $\begin{array}{l}\cdots \\
* \\
* \\
\end{array}$ & * & {$\left[\begin{array}{c}\cdots \\
* \\
\cdots *\end{array}\right.$} & $\begin{array}{l}\cdots \\
\cdots \\
\cdots\end{array}$ & $\begin{array}{l}* * \\
* * \\
* * \\
* \\
*\end{array}$ & $\begin{array}{l}\because \cdot \\
* \\
*\end{array}$ & $\cdots$ & $\begin{array}{l}\cdots \cdots \\
\cdots \\
\cdots \cdots \\
\cdots \cdots \\
\end{array}$ & $\begin{array}{l}\cdots \\
\cdots \cdots \\
\cdots \cdots \\
\cdots\end{array}$ \\
\hline STRAWBERRY & 2 & 3 & $4 \mathrm{E}$ & $4 \mathrm{~W}$ & 6 & 7 & 8 & 10 & 11 \\
\hline Progressive...................... & $*$ & $*$ & $\cdots$ & $\begin{array}{ll}\ddots \cdots \\
\cdots \\
\cdots\end{array}$ & $\begin{array}{c}* \\
* * \\
* \\
* *\end{array}$ & $\begin{array}{l}* \\
* \\
* * \\
*\end{array}$ & $*$ & $\begin{array}{l}\cdots \\
\cdots \\
\cdots \cdots \\
\end{array}$ & $\begin{array}{ll}\cdots \\
\cdots \\
\cdots\end{array}$ \\
\hline
\end{tabular}




\section{Profit and Pleasure in the "Home Fruit Garden"}

Many people do not know how good is the taste of quality fruits picked fresh and ripe in the home garden, because they have tasted only fruits shipped in, which have to be picked before fully ripened. Furthermore, the varieties grown for the market are selected for productiveness, color, and to stand shipping rather than for high quality.

You can grow first class fruit if you will do your part. We guarantee what you order from us to be satisfactory upon arrival and will show you how to take care of it. It is a question of taking only one step at a time. (For information on varieties adapted to your district, see page 37.)

The First step is to select a location. It is better to have the fruit garden some distance from the house than to sacrifice
success by planting on a poor site or soil. A site that is higher than the land around it is preferable since it has better air and water drainage, minimizing danger of loss from frost and avoiding wet feet

most fruit trees and plants abhor. You could have the following in a plot 162 by $131 \mathrm{ft}$.

First row: 5 Apple, $33 \mathrm{ft}$. apart, $15 \mathrm{ft}$. rom the fence. Space between rows $30 \mathrm{ft}$. Second row: 5 Apple, 33 ft. arart. Space
etween rows 25 ft.

Third row: 5 Sour Cherry, 3 Peach, 20 apart. Space between rows $20 \mathrm{ft}$.

Fourth row: 5 Plum, 1 Apricot, 2 Peach 0 ft. apart. Space between rows $15 \mathrm{ft}$

Fifth row: 18 Grape Vines, $8 \mathrm{ft}$. apart.

pace between rows $10 \mathrm{ft}$.

Sixth row: 50 Blackberry, 3 ft. apart.

Srace between rows $6 \mathrm{ft}$.

Seventh row: 50 Rasrberry, $3 \mathrm{ft}$. apart. Space between rows $6 \mathrm{ft}$.

Eighth row: 100 Asparagus, 15 inches part, and 5 Rhubarb, 2 ft. apart.

some varieties need more room when full Trown than others of same kind. Yellow Transparent, a small upright grower, and tree, represent extremes in apple trees.

\section{Planting Distances}

Usual Distance

Apple. . . . . 30 by $30 \mathrm{ft}-25$ to $50 \mathrm{ft}$. apart Apricot. ...20 by $20 \mathrm{ft}$ - 16 to $25 \mathrm{ft}$. apart Cherry, Sweet. 25 by $25 \mathrm{ft}$ - 20 to $30 \mathrm{ft}$. a part Peach or Plum 20 by $20 \mathrm{ft} .-16$ to $20 \mathrm{ft}$. apart Peach or Plum 20 by $20 \mathrm{ft} .-16$ to $20 \mathrm{ft}$. apart Pear, Dwarf..12 by $12 \mathrm{ft} .-10$ to $15 \mathrm{ft}$. apart Pear, Dwarf..12 by $12 \mathrm{ft} .-10$ to $15 \mathrm{ft}$. apart
Quince. . . . 12 by $12 \mathrm{ft}-10$ to $15 \mathrm{ft}$. apart

\begin{tabular}{|c|c|}
\hline 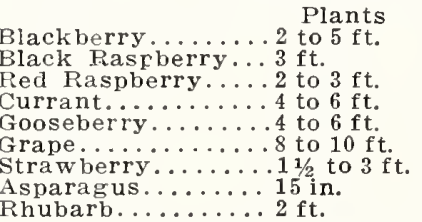 & $\begin{array}{l}\text { Rows } \\
5 \text { to } 7 \mathrm{ft} \text {. } \\
6 \mathrm{ft} . \\
5 \text { to } 6 \mathrm{ft} \text {. } \\
6 \mathrm{ft} . \\
6 \mathrm{ft} \text {. } \\
10 \mathrm{ft} . \\
31 / 2 \text { to } 4 \mathrm{f} \\
3 \mathrm{ft} \text {. } \\
4 \mathrm{ft} .\end{array}$ \\
\hline
\end{tabular}

To determine number of trees per acre for any given distance, multiply distance between trees in row by width of row. Take resulting answer and divide 43,560 of trees, planted $30 \times 30$, required to set one acre. $30 \times 30=900$. $43,560 \div 900=49$ trees per acre.

The Third Step is to send us your order with fuil assurance of a square deal. (See

\section{Preparing the Ground}

Land that has been in some cultivated farm or garden crop is usually in the best condition for fruit trees and plants. Plow deep and work the ground thoroughiy.

An ideal soil, mellow, deep, fertile loam, is not often available and it may even be improve the dirt you have; for instance, for fruit trees dig a hole 5 feet in diameter, throwing the surface soil to one side, then 12 inches, putting it in a pile by itself. Then throw in a few shovelfuls of welldecayed manure. Next throw in the surface soil. In this set the tree and use other surface soil to fill the hole. The other pile of subsoil can be scattered on the surface. Well-rotted manure, wood ashes and ground bone or cottonseed meal can be mixed in with the surface soil used to fill

\begin{abstract}
the hole, but care should be taken to avoid having too much of any fertilizer come in rontact with the roots. For gooseberries feet in diameter and for raspberries and wiack.
\end{abstract}

\section{Handling Trees on Arrival}

If possible plant at once. If the weather is too cold, put the box If the weather is warm and you are not ready to plant, unpack at once and Flace roots with damp packing from the box or bundle and spread old sacks or canvas over them. Sprinkle enough water on the do not drench the roots and tops. If possible heel them in, preferably at the north side of a building where they will have protection from the sun and their develorment will be retarded.

\section{Heeling in Trees}

Select a well-drained location. Dig a trench deep enough and wide enough to hold the roots without crowding. Fine, about the roots. Then heap more soil on the roots and a third or more of the tops. Some growers completely cover the trees. If the ground is too dry moisten the dirt about the roots. Some growers get their trees in the fall and heel them in over hand when conditions are right for planting in the spring.

Treatment for "Dried Out" Trees

Sometimes trees are somewhat dried out in transit but can be restored by burying them in wet dirt or put in a pond for one to three days.

\section{Handling Trees at Planting}

Success is largely a matter of avoiding exposure of roots and tops to the sun or drying winds, and to thorough firming the soil about the roots. Cut off any roots that are extra long and $F u t$ the trees at once in a barrel or tub about semi-liquid of water and dirt (not heavy clay).

\section{Setting the Trees}

Assuming that the ground has been properly prepared, it will not be necessary and about the same depth will be lare nough for the average size apple tree.

The top soil should be put to one side so that
roots.

After a tree has been flaced in its exact position and about as deer as it stood in the nursery, the roots are spread out and thood top soil worked under and around them. Moving the tree slightly up and down will help to get the soil under the
roots. Then fill the hole half full and roots. Then fill the hole half full and hole to the top and again tramp the soil. Lastly throw a few shovelfuls of loose dirt about

If you have to plant when the ground is very dry a bucket of water should be poured around the roots after they have been well covered but before the hole is sary and might do more harm than good. Don't fut manure or other fertilizer in Don't fut manure or other fertilizer in the holes in contact with the roots;

\section{Pruning the Tops}

Even with a special tree-digger and particular care, part of the roots of trees dug in the nursery are cut off and the small feeding roots are lost anyway, so the tops have to be cut back to restore the balance. planting.

one year apple trees, without side branches, are cut off just above a sound bud, 24 to 30 inches from the ground.
Some varieties of one-year budded apple like Jonathan have side branches unless they have been pruned in the nursery. These and two-year apple should have all but 3 to 5 side branches cut off smooth close to the trunk. Select these branches 6 to 8 inches apart. Leave also one branch growing from the top. Shorten this leader a little and cut back the selected side ranches $1 / 3$ to $1 / 2$ their length.

Pear trees are pruned like apple but usually headed lower, 12 to 15 inches from the ground.

Dwarp Pears are usually trained to pyramid form, which calls fol a central nearest the ground.

Peach-The fruit is borne on last year's wood. After the tree is planted, cut of the top 18 to 24 inches above the ground and cut off any side branches about an good buds.

Plums and Apricots are pruned like peach trees.

Onc-year Sweet Cherry are usually $21 / 2$ to 3 ft. from the ground.

Sour Cherry, even one-year, are almost always branched and the general practice is to cut off close to the trunk all but 3 to 5 selected side branch

Quince are headed low, about 18 inches high.

\section{Care of Transplanted Trees}

The first two years is the critical period. It is of vital importance to have them make a good start, for summer drought is likely to prove fatal to trees of low vigor and slow growth. So it is systematically to conserve the moisture and aerate the soil. The first summer the soil should be frequently stirred to make a soil mulch and prevent baking and crusting of the surface. The second summer the ground should first be plowed deep, as early in the spring as possible. Cultivation should be stopped about July 15 th to August 1st that the trees may ration for winter.

\section{Common Causes of Failure to Grow}

1. Planting trees that were dug in the nursery before they became dormant.

2. Drying out from exposure to sun or drying winds, or freezing in the cold before setting out.

3 Crowding the roots into small holes in the sod.

4. Failure to firm the soil closely about

5. Ieaving the trees or plants uncultiated.

6. Leaving the tops unpruned

7. Not planting at the proper depth.

8. Planting in soil too wet or too dry. 


\section{Correct Pruning Is Essential to Success}

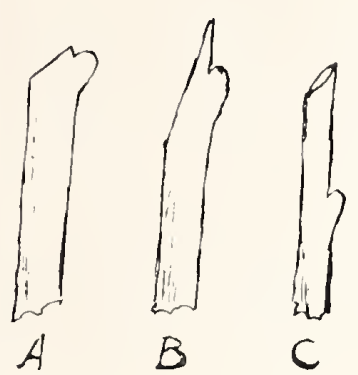

A-Right way to cut twigw. B-Too long a slant. C-Too long a stub. D-Too close to bud.

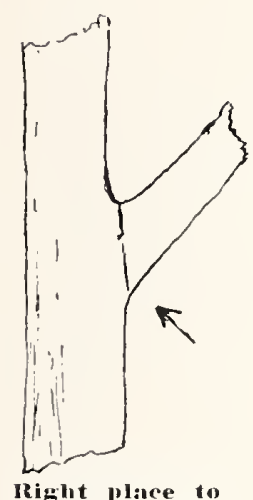

Right place to

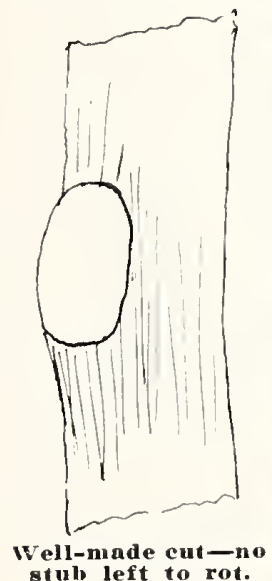

Well-made cut-no
stub left to rot.
$\mathrm{P}$

RUNING is the removal from a plant of the part or parts which are undesirable or superfluous, and the object is to improve results or to make them mole certain. Nature's purpose is the production of a large number of seed, but the gardener wants quality fruit.

The first thing to develop is a good framework to carly a load of fruit and to make it easiest to spray and harvest. One must picture in advance what one wants to accomplish.

HOW TO PRUNE-Make all cuts smooth, close to the trunk or branch, or close to a bud.

TREATING WOUNDS-The general practice has been to paint wounds over two inches in diameter with a pairt of pure white lead and pure linseed oil. Some use creosote, a very thin coating, over the center, but this must not be allowed to touch the young wood or young bark. Some recommend Sodium Silicate ("water glass").

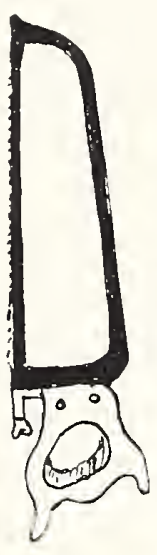
At left, Swlvel-blade Saw-a
good type for pruning.

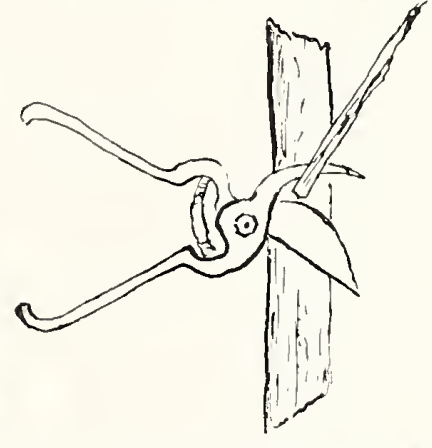

Riglit way to use Pruning Shears that is left.

\section{Pruning Plum}

Plum bears partly on spurs and partly on last season's growth.

Some growers at planting time prune the same as with peach; others, when setting branched one or two-year olds. select three to five branches, cut them back the leader proportionally.

Varieties differ widely in habits of growth. The Japanese varieties grow more like the peach and are pruned much the same. The Burbank is a rank, sprawling grower and needs more heading back.

As a rule it is better to let the trees take their natural form. of course, broken, splitting or interfering limbs should be removed, but heading back and thinning out and summer pinching sideration of the way the tree grows.

\section{Pruning Pear}

The pear also bears fruit like the apple, on "spurs," and is pruned much the same. Most varieties, however, tend to grow in an upright form and are the rule and cuts should be made above outside buds whenever possible. Heavy pruning induces young growth, which is more susceptible to blight.

\section{Pruning Dwarf Pear}

Dware Pears are usually trained to pyramid form, which calls for a central trunk with side branches, the longest nearest the ground. The longest branches, called leaders, are severely headed

This ought to result in growth of side shoots, which should be pinched back during June and July to develop fruit buds. This is done when the shoots have about six leaves, all but three of which are removed. When these shoots send out other shoots the latter should be pinched back to two leaves as soon as three are formed. This pruning is done every year. A main branch or leader may be allowed to rebranch and these should have the shoots pinched back in the same way as those on a main branch.

\section{Pruning Apricot}

Apricot bears fruit on last season's growth and also on fruit spurs.

Pruning is similar to that of the peach. The old wood needs to be thinned out from time to time and the tops will properly pruned every season.

\section{Pruning Cherry}

The fruit is borne largely on spurs, but also from lateral buds on last sea-

One-year Sweet Cherry are "whips" and when transplanted, the top is cut of close to a bud $2 \frac{1}{2}$ to 3 feet from the ground.

Two-year Sweet Cherry and both one and two-year Sour Cherry, are branched and when pruned after planting, from three to seven side branches may be left, selecting those that are well spac
and on different sides of the trunk.

From then on little pruning is re quired. It may be necessary to remove some branches that cross, or some that grow back into the trunk, or some that are too close, or to thin out the top before the branches become so thick that they shade and kill out the lower wood. It is desirable to encourage fruiting in the lower part of the tree. Heavy prunevery year as needed. son's growth.

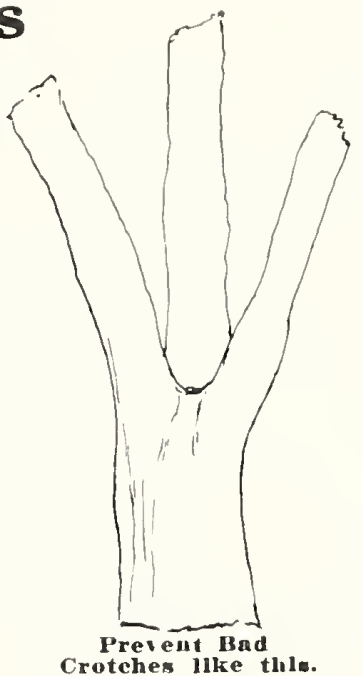

Pruning Peach

The fruit is borne on last year's wood. After the tree is planted, cut of the top 18 to 24 inches above the ground and cut off any side branches about an inch from

During the first season when the growth is four to six inches long, choose three to five side branches on different sides of the trunk and well spaced. Assuming that you select three branches, the highest would be about two feet above the ground and the lowest branch
about a foot. Every three or four weeks about a foot. Every three or four weeks during the first summer, pinch off the these are very numerous, some of them may be cut off close to the trunk. If this pinching is do
will be necessary.

During the second summer select two or three shoots growing outward, not upright, on the main branches and pinch back the others.

During the third summer, less pinching back is required and during the fourth season practically none is necessary. All that is needed can be done in the winter pruning.

The result should be a tree low-headed, spreading, with a well-balanced framework that will produce large crops of quality fruit and come into bearing young.

This style of pruning causes growth at many different points rather than much growth at a few points near the cuts. Severe pruning only seems to produce better growth, this growth is produce better glowth, this growth is lower parts of the tree and the total growth of the tree is diminished.

As the trees get older it will be necessary to prune the tops more heavily in late spring (some growers delay this pruning until the trees are in full bloom). If the twig and limb growth lower down in the tree begins to die out it indicates that the centers and top are
not open enough. If these twigs and not open enough. If these twigs and limbs in the lower part of the tree de-
velop a long growth it shows the top and centers are too open.

If you have old trees that seem to need heavy pruning, cut back moderately, say three to five feet, making a smooth cut to a good sized limb extending outward. Then the following summer when the new growth is one or two feet long, re-
move the strong sprouts that push out where new limbs are not desired.

\section{Pruning Quince}

The fruit is borne at the tips of shoots that grow out the same season from last year's wood. They should be headed low. about 18 inches. This will give enough runk up to the lowest branch.

Pruning should aim to keep the top open and well spread out by removing superfluous interior branches and by shortening the shoots where frult is desired. 


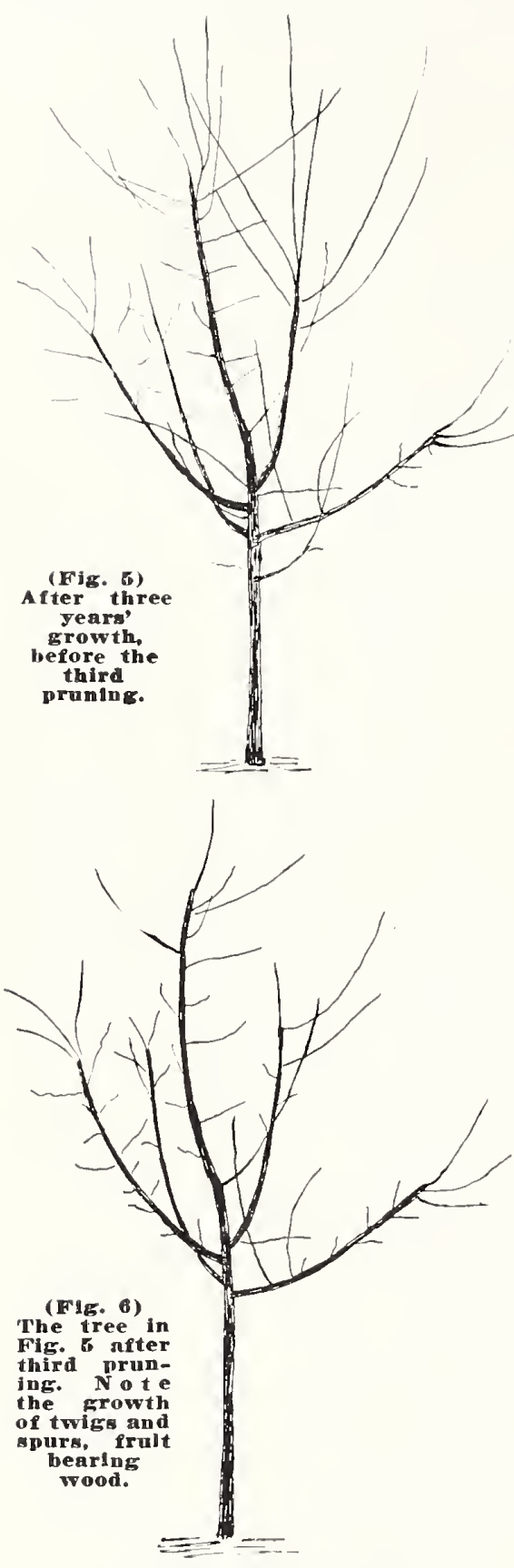

"Never Lost a Tree!"

"The trees (50 apple, 2 plum, 1 yr. $5 / 16)$ I got from you last fall did remarkably well. I never lost a tree."Virgin Sooter, Mo.

\section{Pruning of Apple Trees}

The apple bears on "spurs" and this fruit-bearing wood must be encouraged and preserved.

The best form or shape is the Modified Leader Type, which has more and better fruiting wood, is likely to bear younger, avoids weak crotches and has well-spaced branches and a low, spreading top. The training to this type is as follows:

If the tree you plant is a "whip" (with no side branches), the only pruning is to cut off the top 28 to 30 inches from the ground. This is to restore the balance between the top and the root system since a part of the roots may have been lost in digging and the small fibrous roots have to form again from the larger roots.

Assuming that a whip has been planted, during the first summer pick out the branches you want to keep and pinch back the others. This will cause the selected branches to make a better growth.

At the end of the first growing season, before growth starts in the spring it will be necessary to cut off close to the trunk all the branches except those selected to form the framework of your tree. 'I'hen shorten the leader a little and also any sicie branches that are too long or unequal in length. See Fig. and 2 .

If you plant a well-branched tree (some varieties of one-year budded apple are well-branched), it will be necessary to remove all but 3 to 5 side branches, selecting those well distributed about the trunk and spaced 6 to 8 inches apart Also leave one branci growing from the top which will be the lower This should be shortened a litteader. This should be shortened a lit cut and the side branches selected also cut bact

\section{Fruit Tree "Fillers"}

Fillers are trees set between apple trees, and may be cherry or peach or young-bearing, smaller growing apple trees like Yellow Transparent, Duchess of Oldenburg. Wagener. Wealthy, King David Cherry and peach are not as David. Che methods desirable as apple because the methods of handin

of course filler trees must be removed when they begin to crowd the permanent trees There should be no more hesitation about cutting out the fillers than in removal of a limb at pruning time.
The fourth season two or three more side branches should be selected from the central leader and these may be headed back if they threaten to overshadow the lower limbs. When you have sufficient side branches, probably about six, the leader should be cut off just above the top side branch.

From then on pruning should be as little as is necessary for the proper spac ing of framework branches and keepins them in proper proportion. It will be confined to removal of branches or proportion to other branches.

The upper third of the tree should be the thinnest and the lowest the densest, to help maintain good wood all over the tree. This calls for checking of the stronger branches and giving the lower limbs an equal chance to grow and fruit well. In, in heading back, cuts are made to relatively good sized lateral branches, there will be less suckering and quicker healing than if cuts are made back to smaller laterals. However, fertilization and cultivation may be necessary to secure the desired growth throughout the entire tree.

Bear in Mind-as trees grow older, two varallel branches even 12 to 18 inches apart will crowd each other and one will have to be removed. Also two branches that cross each other 5 or 6 inches apart near the trunk of the tree will in time crowd each other and one will in time crowd each other and one should be to voided be remedied as early as possible.

Cutting a branch heavily lessens tota growth of that part

Pruning a branch lightly increases the total growth of that part.

Two branches growing out from the same place will form a bad crotch. Head one back more than the other, which in time will become the leader or main branch, while the shorter will become a side branch.

"Heading back" is cutting off a part of, or reducing the length of, a shoot or branch.

"Thinning out" means the removal of the entire shoot or branch.

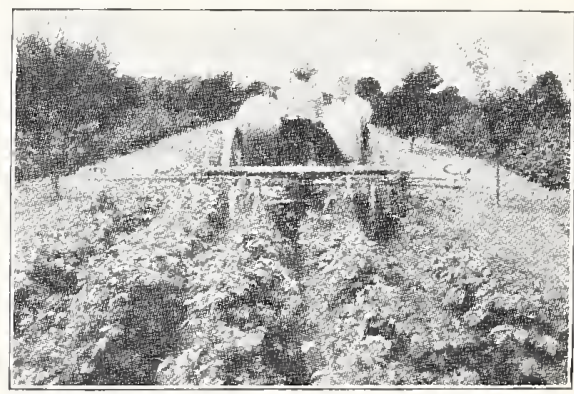

llake the land between the soung trees bas dividends.

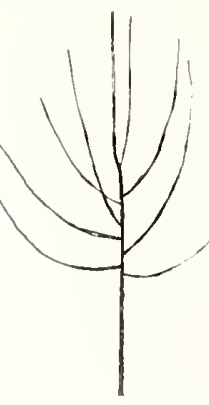

(Tig. 1) At end of first seanon's frowtlı (if a "whlp" irga planted), and liefore pruning.

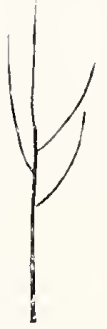

(Fig. 2) Same tree as in Fig. 1, but after pruning. If you eould look dow on the tree you would see that the three side branelies eome out on differ-
ent sides of the trunk.

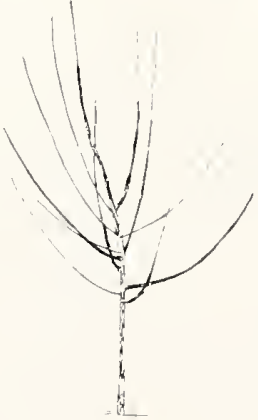

(Fig. 3) This shows the (rig. 3) This shows the tree after two seasons and the leader as well as
rowtl and before the the hranelies have been seeond pruming.

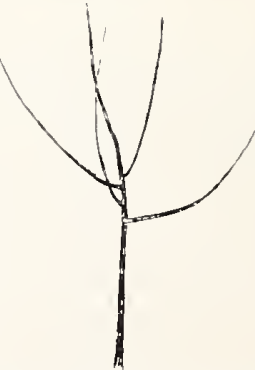

(Fia. 4) The tree in Fitr. 


\section{Pruning of Grape Vines}

The fruit is borne on shoots that put out from last year's growth. When the plants are set, cut off the tops so as to leave two or three good buds, and shorten the roots to about eight inches. The first summer the vines are allowed to grow at will.
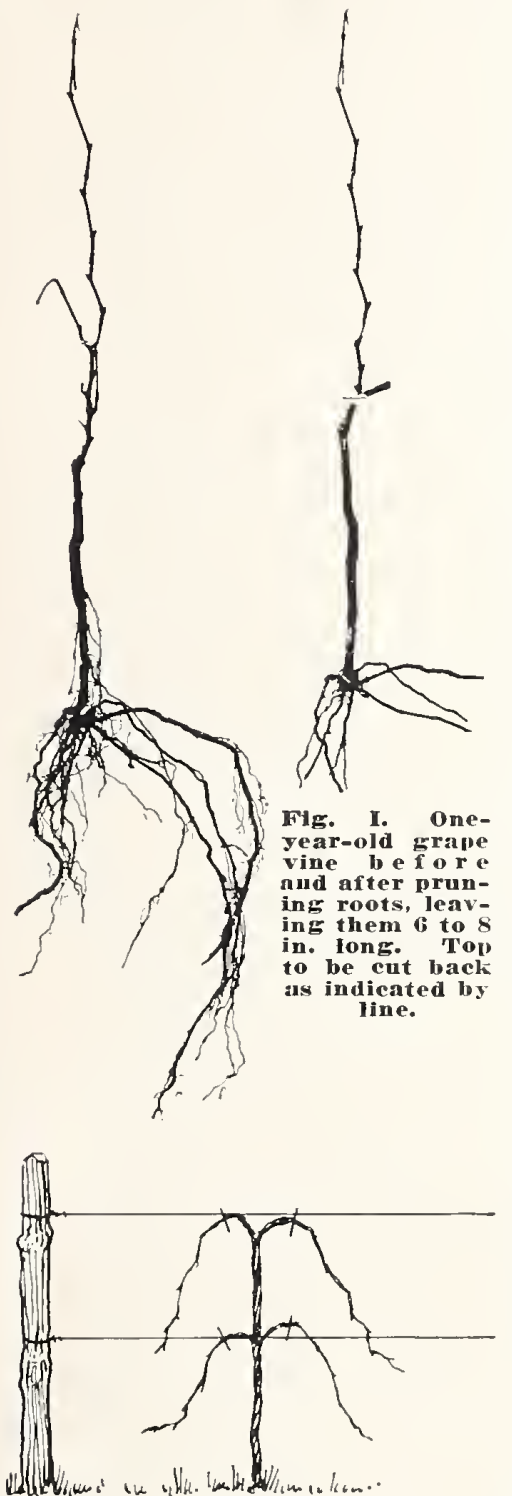

Fig. II. End of sceond summer. During that summer the top of the cane was piuched off and also all slioots except four. Lines sliow where eanes are pruned the follow-
ing sinter.

\section{Why Fruit Trees Fail to Bear}

The blossoms of some varieties are more or less self-sterile, that is, the pollen of the variety will not fertilize its own blossoms. Home orchards usually consist of several varieties of the same kind and this difficulty is not often present. In commereial blantlng it ls wise to plant say four rows of one variety, alternately witl four rows of another. That is the best plan even with self-fertile varieties like Grimes and Jonathan.

Lack of pollination, and therefore a crop failure, may be due to cold, wet weather at blossoming time.

Failure to bear may also be due to the condition of the trees. If the tree makes a small amount of new growth, the
The following spring before growth starts select the most vigorous cane, cut it back, leaving two good buds and remove entirely all the other canes. a strong growth has been made the cane selected half to three feet. It will then be necessary to te on a definite system of training.

The most popular is the four-arm Kniffin System. This calls for a trellis of two wires. Posts about ix to seven and one-half feet tall are set 18 to must be braced. Number 9, 10 or $12 \mathrm{smooth}$ wire wo and one-half to three feet from the ground and the other wire two to two and one-half feet

The second summer when the new shoots are about a foot long, select the straightest and strongest and cut off the other shoot or shoots. This selected shoot or cane should be tied to the wire, or a stake if the trellis has not already been put up. When this cane reaches the top wire it should be tied to that wire and growth above that wire pinched or cut off. This will force out side start, except from near the upper and lower wires.

The following spring before growth starts, choose wo side branches or laterals to run along each of the two wires. Shorten these back so as to leave laterals to one bud.

The third year, remove in summer the shoots that come out on the trunk between the wires, between the lowest wire and the ground, and any that come up from the roots. In the spring select according to the vigor of the plant and cut back ther laterals to one bud.

Pruning Bearing Vines, Kniffin System

Save four strong canes, one on each side of the

Cut these to about 3 feet long for the top wire about an inch beyond the lower wir

Cut off other canes, except that two as near the wires as possible should be cut back to two buds to make fruit bearing wood for the next season.

Winter pruning may be done any time after the eaves fall until growth starts in the spring, but with small plantings it is better to wait until just before growth starts. In any case do not easily broken in handling.

The amount of fruiting wood to leave when pluning varies with the vigor of the vine. An and still grow good fruiting wood about 15 pounds year. On such a vine, a total of 30 to 35 buds should be left.

\section{RABBIT AND MICE PROTECTION} of galvanized wire clotl of one-fourth inch mesh. Many use paper but remove it in late spring. Some Lime Sulphur and Arsenate of Lead or White Lead and Linseed oil.

Mice injury can be prevented by keeping any wecds or grass away from the trunk or by wire protectors which should be pushed into the ground couple of inches. s stretched tight on the posts, the lowest wire trunk for each of the two wires.

The best way is to put around the trunk a roll

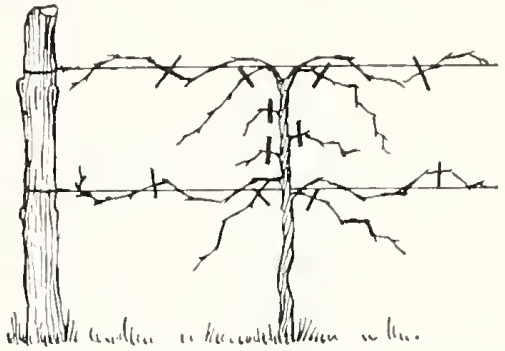

Fig. III. Showe growth during third season. Linea show pruning the winter followlng.

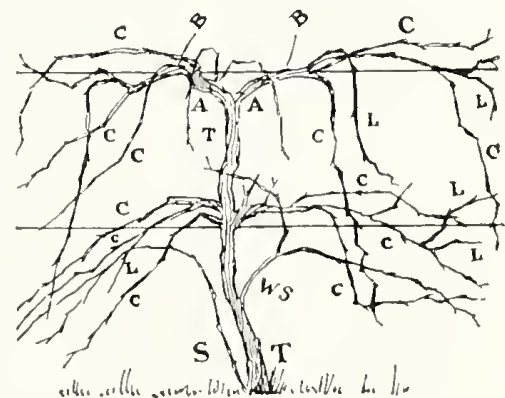

Fig. IV. Mature Vine.

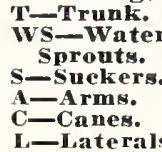

slioots of a canc.

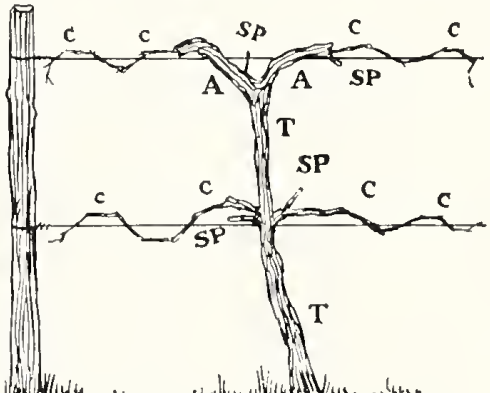

Flg. V. Mature Vine Pruned. T-Trunl:

C-Canes, one ycar old, on whlch fruit is borue.
frut srov for fruit tlic next sear.

"A Neosho Booster"

"Highly pleased. Wonderful stock. Enthusiatic abont the manmer ln which your business is conducted. Grafts on j-in-1 apple beantiful work."-lR. H. Rembert, v. C.

\section{INTERCROPS}

Fruit trees do not use all the ground the first few years and various crops are sometimes used to secure earlier returns from the land. Annual crops such as early beets, turnips, radishes, peas and beans are good, but late vegetables should be avoided since they require late cultivation, which prevents the trees from maturing properly before cold weather. Currants, gooseberries, strawberries and raspberries have also produced good results. With strawberries there is danger that the trees will not receive proper cultivation after the first season.

Grain crops should never be used.

A space 6 to 8 ft. should be left unplanted along each row of trees and in creased in width each year.

of course, if intercrops are grown more liberal fertilization must be given. 


\section{Avoid Losses by Control of Insects and Disease}

Eating Inseets-Eating Insects are controlled by a stomach poison. Arsenate gallons of water. In small quantities, 1 tablespoon to 1 gallon of water.

Sueking Inseets-Sucking Insects are controlled by a contact body poison (nicotine sulphate or miscible oils). Fo phate is used, $1 / 2$ pint to 50 gallons of water and 2 lbs. of soap. For small quantities use 1

Hard shell scale types of sucking insects are controlled by spraying with a strong mixture of lime sulphur

Fungous Diseases, such as apple scab. blotch, bitter-rot, cherry leaf spot and peach and plum brown-rot are controlled by either lime sulphur or Bordeaux
mixture. Use summer strength so as not to injure fruit or foliage.

\section{SPRAY MATERIAS}

Lime Sulphur, a commercial preparation, can be secured in either liquid or dry form. Following directions for liquid: of water, 1-8. For trees in foliage or summer streng Self-boiled Lime Sulphur is prepared in a barrel and nearly covering it with water. When the lime begins to slake, add 8 lbs. of powdered sulphur which has been previously sifted to remove all lumps. Stir this mixture constantly. adding more water as needed until a thin paste is secured. Then add immediStrain the mixture thoroughly.

Bordeaux Mixture is used in different strengths. $4-4-50$ is considered standard strengths. $4-4-50$ is considered standard
strength and indicates 4 lbs. copper sulphate, 4 lbs. unslacked lime to 5 gallons of water. Prepare mixture by dissolving 4 lbs, of copper sulphate in one vessel, slacking 4 lbs, of lime in another, pour together, stir well and add enough water to make 50 gallons. preparations can be purchased.

Heary Engine oils are being used of late years in dormant spraying for control of scale. Write to U. S. Dept. of Agriculture or State Experime
for directions. (See page 29.)

Spray Equipment-The size of the spray outfit depends on the work to be accomplished. In general for shrubs and small garden work a 3 gallon compressed-air tank will be sufficient. For large gardens and home orchards, a barrel sprayer. For commercial orchards you in touch with reliable manufacturers of spray outfits.

\section{CONTROL OF RORERS}

These pests of apple and peach trees must be killed by a wire thrust into their tunnels, disclosed by removing a few inches of dirt around the base of the tree. Go over your trees in April or May and in late August or September. the dirt around the trunk about 6 inches high.

The Flat-head Apple Tree Horer is the limbs and more often on weak or diseased trees.

The Peach Horer can be destroyed in trees 5 years old up by spreading about an oz. of Paradichlor-benzine in a narrow ring around the tree, not closer than two inches from the trunk, and covering this chemical with several inches of dirt well packed dow FIRE BLIGH'T

This disease sometimes attacks certain varieties of apple and pear. The small shoots turn brown and die and the bark finally becomes blackened. The only fected parts, making the cut six inches below any sign of the disease and burning the bliglited parts. 'The tools and the wounds are disinfected with bichloride of mercury, corrosive sublimate, a deadly plied with a sponge or rag.

\section{Spray Calendar for Apple, Pear, Quince}

(1)-Dormant or Seale Spray. Any time after leaves drop in the fall, during pleasant weather in winter

For-San Jose Scale, Other Scale Insects, Plant Lice (Aphids).

Use-Commercial liquid lime-sulphur to 7 or miscible oils. This spray present. Arsenate of lead is not required.

(2)-First Summer or Cluster Bud Spray. When cluster buds are separated
and the pink petals show, but before the blossoms open.

For-Plant Lice (Aphids), Apple Scab Curculio, Canker Worms, Apple Rust, Leaf Spot, other biting insects. plus 1 lb. of dry arsenate of lead. of spray mixture when plant lice are abundant).

(3) - Second Summer or Calyx-Cup Spray. Start when bloom is two-thirds of and finish before the blossom ends close. Most important

For-Codling Moth, Plant Lice (Aphids), Apple scab, Leaf spot, Curculio, Canker Worms, Lesser Apple Worm, other biting insects.

Use-Lime-sulphur $(11 / 2$ to 50$)$, see note, plus 1 lb. of dry arsenate of lead. of spray mixture when plant lice are abundant)

(4)-Third Summer Spray. Within 12 to 15 days after Calyx spray. If Cur6 or 7 days.

For-Apple Blotch, Sooty Blotch, Leaf Spot, Curculio, Codling Moth, Lesser Apple Worm, other biting insects.

Use-Lime-sulphur ( $11 / 2$ to 50$)$, see note apple blotch is severe use Bordeaux $3-4-50$

(5)-Fourth Summer Spray. Apply 5 or if No. 4 is made within 6 to 10 days, apply No. 5,2 to 3 weeks later.

For-Apple Blotch, Sooty Blotch, Curculio Codling Moth, Lesser Apple Worm, other biting insects.

Une-Lime-sulphur (11/2 to 50), see note. or Bordeaux $3-4-50$, plus 1 lb. of dry is severe, use Bordeaux 3-4-50.

Fifth Snmmer Spray. Apply about 2 or weeks after No. 5 or 7 to 9 weeks after Calyx spray. Make later sprays at intervals of 10 days or 2 weeks, where
rot is serious.

For-Coddling Moth, Lesser Apple Worm, Apple Blotch, Bitter Rot, Sooty Biot.

Use-Lime-sulphur ( $11 / 2$ to 50$)$, see note, or Bordeaux $3-4-50$, plus 1 lb. of dry arsenate of lead. If apple blotch or bitter
Bordeaux $3-4-50$.

\section{Spray Calendar-Grapes}

(1) - In the spring before buds begin to

For-Scale, Anthracnose.

Use-Lime-sulphur solution, win t e r strength for both Scale and Antriple strength for Anthracnose.

(2) -As buds are swelling. Repeat in

5 to 7 days.

Use-Lead Arsenate (dry) 3 lbs. to 50 gallons.

(3) -When shoots are showing second or third leaf.

For-Black Rot, Anthracnose, Flea Beetle.

Use-Standard Bordeaux for rot. Lead Arsenate (dry) 3 lbs. to 50 gallons for insects, if needed.

(4)-Before blossoms open.

For-Black Rot, Anthracnose, Curculio, Flea Beetle, Berry Moth.

Use-Standard Bordeaux for rot. Add 2 lbs. of soap to each 50 gallons. Use Lead Arsenate (dry) 2 lbs. to 50 gallons for insects.

(5)-After blooming.

For-Black Rot, Anthracnose, Curculio, Berry Moth.

Use-Same as for preceding application.

(6) -10 to 14 days after blooming.

For-Black Rot, Anthacnose, Insects.

(7) - 3 to 4 weeks after blooming.

For-Black Rot, Anthacnose, Insects.

( 8 )-About 6 weeks after blooming. One later application may be necesSary. Rot, Insects.

For-Black Rot, Insects.

The spray program for grapes centers around the treatment for black rot. The usual recommendations include three sprayings before blooming after blooming and two weeks after blooming. In
vineyards where the disease is of mod- erate consequence, three sprayings may be sufficient, but where it is severe, flve to seven may be required.

Sprays Required-The apple sprays ordinarily needed are $2,3,4$ and 5 in the northern half of Missouri, while in the southern half 5 or more sprays are generally required. Every fruit grower should study carefully the conditions in pests and plant diseases, in order to be able to work out a spraying program best adapted to his own particular needs.

\section{Spray Calendar Cherry, Peach, Plum}

(1) - Any time after leaves drop in fall, during nice weather in winter and spring.

For-Peach Leaf Curl, Brown Rot, San Jose Scale.

Use-Commercial lime-sulphur (1 to 7 ). If scale is not present use Bordeaux mixture $(4-4-50)$ or lime-sulphur

(2)-Apply after blossoming and when most of the shucks and blossoms are off the fruit.

For-Curculio. other biting insect. Peach Scab, Cherry Leaf Spot, Brown Rot, Plant Lice (Aphids)

Use-Arsenate of lead, dry, $3 / 4 \mathrm{lb}$, in selfboiled lime-sulphur $(8-8-50)$, or in 50 gal. of water to which is added milk of lime, from 2 to 3 lbs. of stone lime. Add nicotine sulphate $1 / 2 \mathrm{pt}$ to 50 gal.
are injurious.

(3)-Apply 6 to 10 days after shucks and blossoms are off. If curculio is and blossoms are off

For-Curculio. other biting insect, Brown Rot Peach Scab Cherry Ieaf Spot. Plant Lice (Aphids)

Use-Self-boiled lime-sulphur $(8-8-50)$ plus $3 / 4 \mathrm{lb}$. of dry arsenate of lead.

(4)-Apply 2 to 3 weeks after No. 3 or at least 3 weeks before fruit ripens.

Iar-Curculio. other biting insect, Brown

Use-Self-boiled Scab, Cherry Leaf Spot. plus $3 / 4$ lb. dry arsenate of lead.

stone Frults - Where San Jose Scale and Peach Leaf Curl are not present, sprays No. 2 and No. 3 will generally afford sufficient protection.

During wet season, Elberta and later varieties of peaches may need later applications of self-boiled lime-sulphur $8-8-50)$, but in no instance should any ariety of stone fruit be sprayed with picking time. 


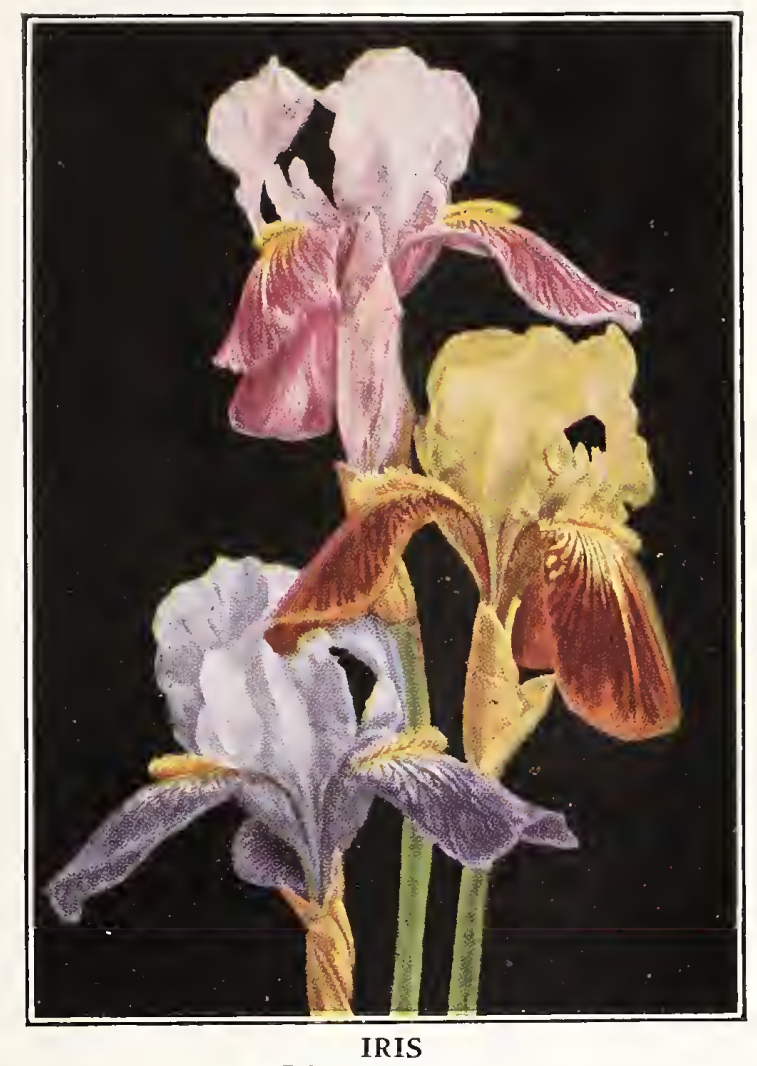

Iris germanica

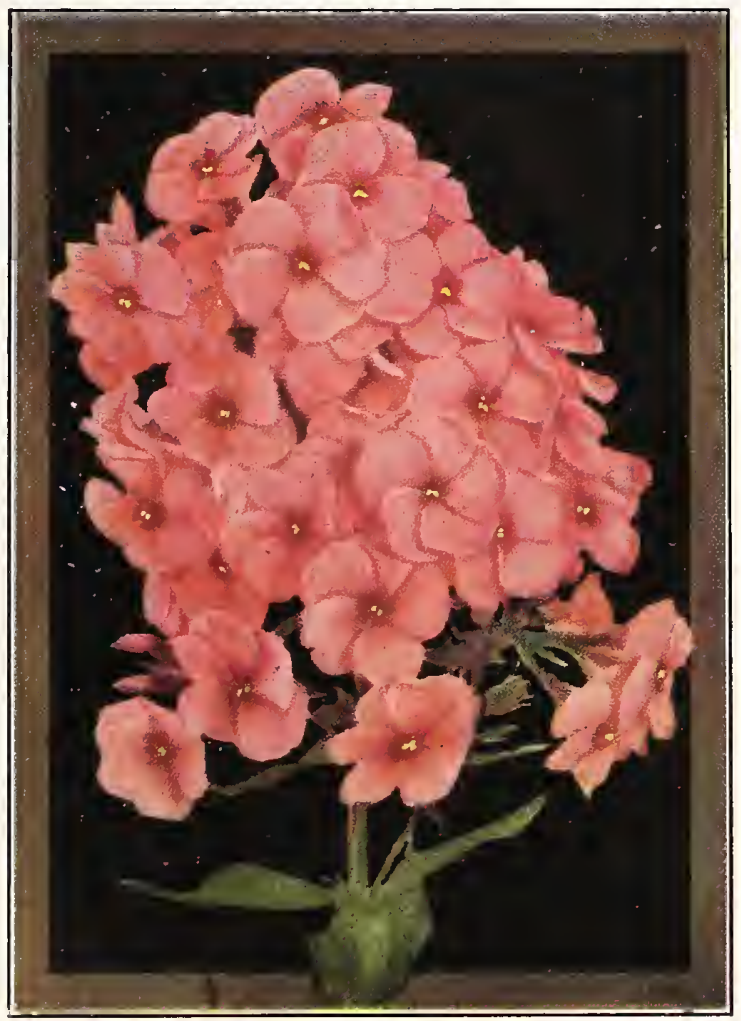

PHLOX (Thor)
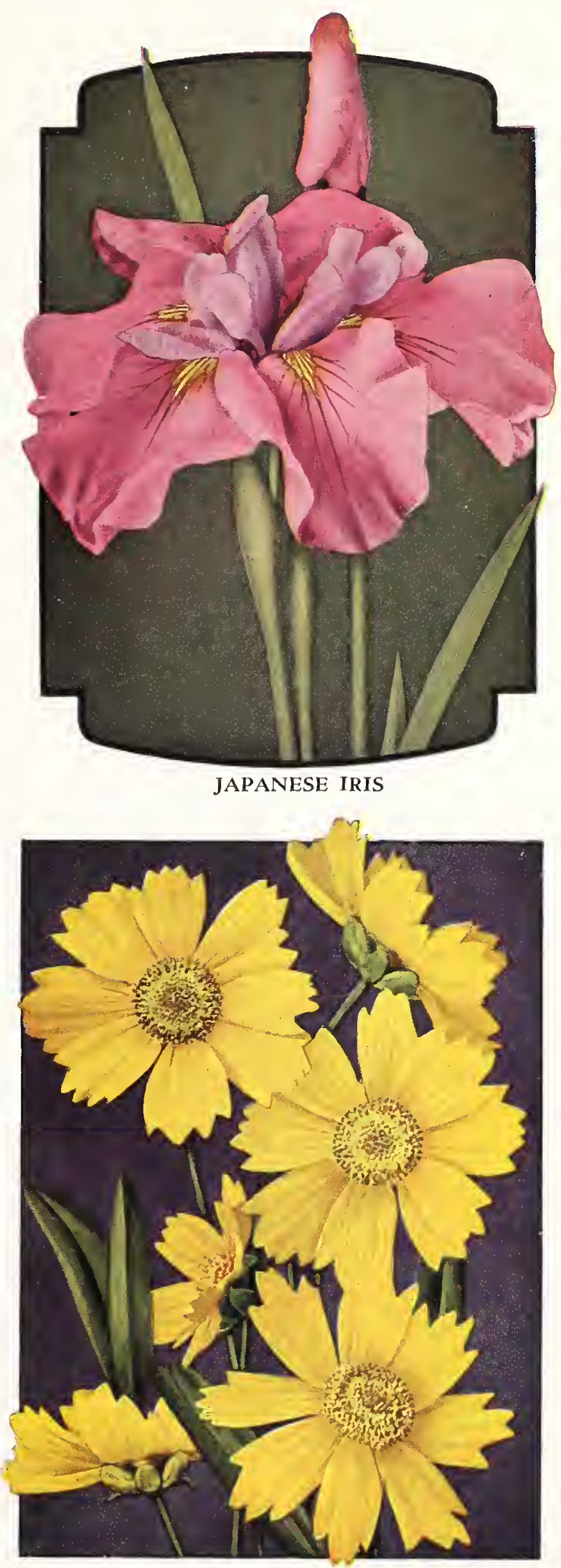

GOLDEN DAISY (Coreopsis)

Lovely Iris, April into June. Beautiful Phlox and Golden Daisy, all summer. Plant this fall for next season NEOSHO NURSERIES CO., Neosho, Missouri 


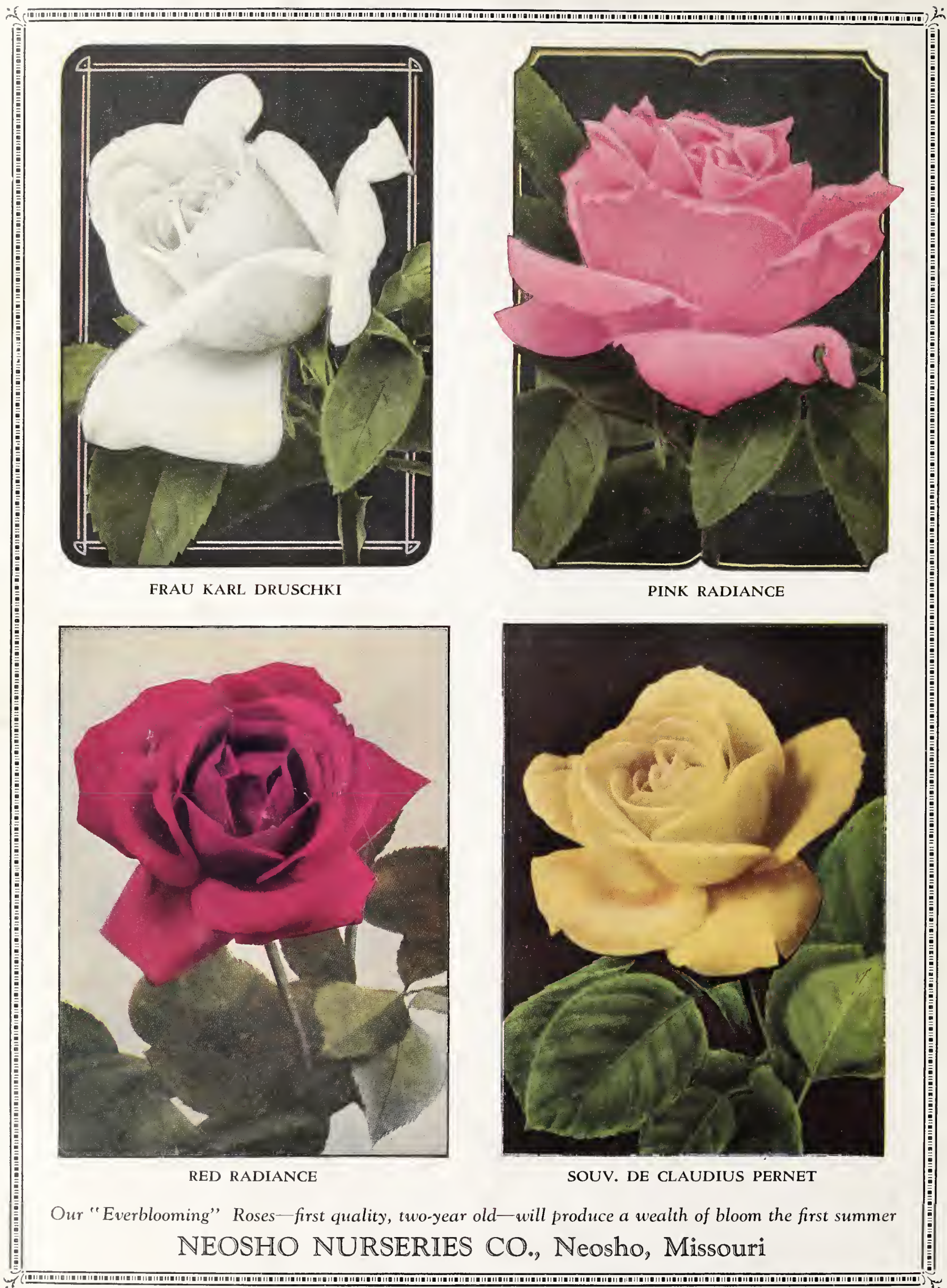

